Florida International University FIU Digital Commons

\title{
Constructing Childhood: Place, Space and Nation in Argentina, 1880-1955
}

Melissa Malone

Florida International University, marmi002@fiu.edu

DOI: $10.25148 /$ etd.FIDC000128

Follow this and additional works at: https://digitalcommons.fiu.edu/etd

Part of the Latin American History Commons, and the Other Geography Commons

\section{Recommended Citation}

Malone, Melissa, "Constructing Childhood: Place, Space and Nation in Argentina, 1880-1955" (2015). FIU Electronic Theses and Dissertations. 2173.

https://digitalcommons.fiu.edu/etd/2173

This work is brought to you for free and open access by the University Graduate School at FIU Digital Commons. It has been accepted for inclusion in FIU Electronic Theses and Dissertations by an authorized administrator of FIU Digital Commons. For more information, please contact dcc@fiu.edu. 


\title{
FLORIDA INTERNATIONAL UNIVERSITY \\ Miami, Florida
}

\section{CONSTRUCTING CHILDHOOD: \\ PLACE, SPACE AND NATION IN ARGENTINA, 1880-1955}

\author{
A dissertation submitted in partial fulfillment of the \\ requirements for the degree of \\ DOCTOR OF PHILOSOPHY \\ in \\ HISTORY
}

by

Melissa Anne Malone

2015 
To: $\quad$ Dean Michael R. Heithaus

College of Arts and Sciences

This dissertation, written by Melissa Anne Malone, and entitled Constructing Childhood: Place, Space and Nation in Argentina, 1880-1955, having been approved in respect to style and intellectual content, is referred to you for judgment.

We have read this dissertation and recommend that it be approved.

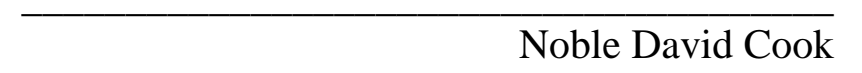

$\begin{array}{r}\text { Ricardo Salvatore } \\ \hline \text { Patricia Price } \\ \hline \text { Rebecca Friedman, Major Professor }\end{array}$

Date of Defense: July 1, 2015

The dissertation of Melissa Anne Malone is approved.

\begin{tabular}{r} 
Dean Michael R. Heithaus \\
College of Arts and Sciences \\
\hline Dean Lakshmi N. Reddi \\
University Graduate School
\end{tabular}

Florida International University, 2015 


\section{ACKNOWLEDGMENTS}

I am thankful for the support received from Florida International University's Dissertation Evidence Acquisition Fellowship and Dissertation Year Fellowship, Andrew W. Mellon Foundation’s Wolfsonian-FIU Graduate Fellowship, and a Tinker Field Research Grant. Thank you to my dissertation committee, Patricia Price, Noble David Cook and Ricardo Salvatore, for your careful readings and advice. Thank you Rebecca Friedman for chairing the committee, for years of inspiration, and for dedicating your time to seeing the project completed. Thank you Mark D. Szuchman, for years of support and critical advice. I am forever grateful for the education and support I received from the students, faculty and staff at Florida International University’s Department of History and Latin American and Caribbean Center.

I owe many thanks to my loving Buenos Aires family, especially the late Gerardo Hellemeyer and his wife, Marta, for opening their hearts and their beautiful home to me. I am especially grateful for the guidance and support I received from scholars and staff at the Archivo General de la Nación (AGN) and the Biblioteca Nacional de Maestros (BNM). Thank you, Ivanna Margarucci, for your generous time and research support in the archives.

Finally, I’d like to thank my eternally supportive family and friends, especially my parents Randy and Kathy Armitage, for always believing in me and encouraging me to be my best self, and most of all my husband, Jonathan Malone, for providing the love, patience and support one needs to complete a dissertation. 


\begin{abstract}
OF THE DISSERTATION
CONSTRUCTING CHILDHOOD:

PLACE, SPACE AND NATION IN ARGENTINA, 1880-1955
\end{abstract}

by

Melissa Anne Malone

Florida International University, 2015

Miami, Florida

\title{
Professor Rebecca Friedman, Major Professor
}

During the vastly transformative stages of the late nineteenth and early twentieth centuries, notions of the urban and definitions of childhood mutually intersected to create and define a modern Argentine landscape. The construction of new urban environments for children defined and reflected larger liberal elites' definitions of childhood writ large. To better understand the production of this modern childhood in Argentina, this dissertation examines its other through the spatial-discourses behind constructions of childhood for the socio-economic lower classes - children who largely did not meet the expectations of the elite.

I employ the use of both published and archival sources, from 1880 to 1955, providing textual analyses of the language of reformers - primarily state and municipal authorities, pedagogues, hygienists, philanthropists and urban planners - alongside spatial analyses of the built environment, including kindergartens, playgrounds, and open-air schools within the city of Buenos Aires, as well as a healthcare facility and themed park in the province of Buenos Aires. Urban intellectuals, educators and overall reformers increasingly considered play as paramount to children's physical and psychological 
development, focusing on where children played, how they played and what their play meant. Childhood became a contested ideological space, constructed and negotiated alongside notions of Argentine national identity. By moving beyond textual analyses of professionals' discourses, this dissertation not only contributes to our understanding of Argentine childhood, but also points to ways in which the built environment embodies modern notions of childhood. 


\section{TABLE OF CONTENTS}

CHAPTER

I. CHILDHOOD IN FIN DE SIÈCLE BUENOS AIRES......................1

Constructing Children's Geographies................................... 4

The City as Playground................................................ 19

The Urban Open Landscape.............................................. 24

II. LEARNING THROUGH PLAY ........................................ 33

A Kindergarten Age................................................... 33

Kindergarten or Jardín de Infantes....................................44

Between Home and School.............................................. 48

III. THE BOUNDARIES OF PLAY ............................................ 63

Unequal Landscapes............................................................ 63

Saving the Children................................................ 72

The Playground Movement............................................78

Palermo de los Pobres.............................................. 92

IV. INSIDE THE SANATORIO Y SOLARIUM MARÍTIMO................... 103

The Landscape of the Climate Cure....................................................107

Childhood in the Asilo................................................................................... 118

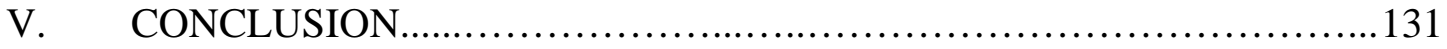

Peronist Visions of Childhood............................................ 134

La Republica de Los Niños.............................................141

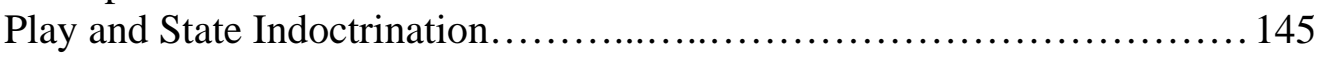

REFERENCES......................................................... 150

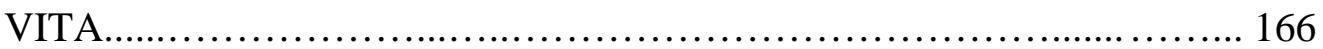


2.1 Children at recess in kindergarten, Buenos Aires, $1899 \ldots \ldots \ldots \ldots \ldots \ldots \ldots . . . . . .51$

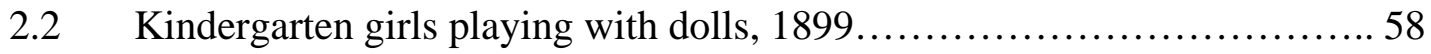

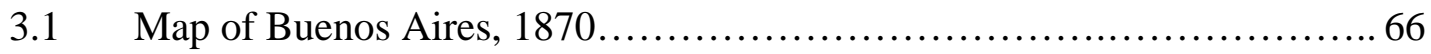

3.2 Casa de Niños Expósitos, Buenos Aires...................................70

3.3 Batallones Escolares, 1889.......................................... 79

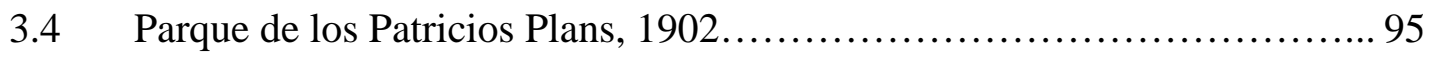

3.5 "Chicos de la quema” before Parque de los Patricios ..............................97

3.6 Escuela Patria classroom, 1908........................................98

3.7 Children exercising in Parque de los Patricios............................. 99

3.8 Daily medical examination at Lezama, $1915 \ldots \ldots \ldots \ldots \ldots \ldots \ldots \ldots \ldots \ldots \ldots \ldots . . . \ldots 101$

4.1 Solarium de Mar del Plata, 1926.......................................112

4.2 Girls resting inside the Solarium de Mar del Plata.......................... 114

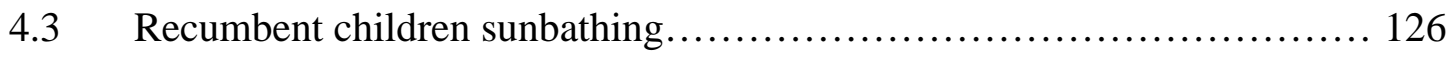

4.4 Children playing on the beach at the Asilo Marítimo........................128

4.5 Children playing in the sand at the Asilo Marítimo .......................... 129 


\section{CHAPTER I}

\section{CHILDHOOD IN FIN DE SIÈCLE BUENOS AIRES}

Concepts of play were paramount to normative notions of childhood in the discourse among educators, reformers and hygienists in Buenos Aires at the turn of the nineteenth century. In a 1916 Monitor de la Educación Común article, titled “El Juego,” medical inspector Luis R. Cassinelli presents the foremost theories on how play is both natural and necessary in the development of a healthy, happy childhood. Through play, Cassinelli articulates, the child's body learns movements and creates functions that are necessary for adulthood. Play, then, was defined by "a set of movements or actions," with a visible sense of pleasure, that, especially in children, develop and improve "physiological and psychological functions." widely accepted as a tool to shape modern childhood and consequently to shape future adults of the nation. Like Cassinelli, hygienists, educators and other reformers throughout the Americas touted the transformative benefits of the physical and psychological development of childhood through play. State and municipal authorities in Buenos Aires were urged to develop more outdoor public spaces of recreation, including parks, playgrounds, gardens and schools.

These projects to construct new spaces for children provided a place for burgeoning reformers, planners and other professionals to define modern childhood, often in contradiction to liberal-elite conceptions of what childhood should be. Especially in the city of Buenos Aires, many new spaces were constructed for populations that did not

1. Luis R. Cassinelli, “Los Juegos,” Monitor de la Educación Común (1916). A lecture given by Dr. Cassinelli to teachers at the Escuela para Niños Débiles del Parque Lezama. 
"fit" into the state's positivist view of the "healthy" child. The conception of and construction of new environments helped to define a normal "modern” Argentine childhood. These professional conceptions largely defined a "natural" childhood as one centered on education, hygiene and play. However, planned environments for children reveal the conception of space where adults' understanding of childhood intersected with - or missed - the participation of children in public life. The boom of new institutions to shape and rehabilitate every aspect of working class children's lives indeed reveals deep inequalities amongst children of varying socio-economic situations. Childhood, thus, acted as a contested ideological space, constructed and negotiated within Argentina's landscape. Contributing to the historicization of the child's place in the built environment, this dissertation acts as a case study to reveal the ways in which spatial analyses provide unique insights into the construction of childhood in Argentina's nationstate development.

The ways in which government authorities and reformist professionals constructed and defined childhood through play is as an overarching theme throughout this dissertation. Especially in the twentieth century, across the globe, play came to be regarded by an emerging group of professionals for its theoretical function in the development of desirable behavioral, physical and social traits in children. This chapter serves as a historiographical introduction to the history of childhood and children's geographies, and examines how urban spaces in Buenos Aires acted as a playground for planners, educators and reformers to experiment with concepts of childhood, modernity and nationhood. The subsequent three chapters examine the construction of childhood through the lens of spaces created explicitly for children in the late nineteenth and early 
twentieth centuries. The second chapter acts as an origin story to the development of jardines de infantes, or kindergartens in Argentina. The analysis reveals how new nineteenth century Pan American pedagogical concepts of play promoted in early childhood education served to renegotiate the place of the state in everyday family life. The promotion of self-discovery and free play as an educational tool in childhood served to shape Pan-American ideas about modern childhood education, yet kindergartens also acted as a platform to express elite distrust of working class families. In the third chapter, I examine the sometimes-unequal development of parks and playgrounds in Buenos Aires. At the turn of nineteenth century, the new landscape of Buenos Aires provided more spaces for recreation and leisure for working class children, however spatial discourses reveal these new spaces also served aspirations to sanitize and define the boundaries of the working class. I posit programs of physical recreation and open-air schools within the southern barrios of Buenos Aires as part of a broader child-saving movement, examining the efforts of urban reformers to both normalize childhood and contain children who did not meet the expectations of the emerging middle class. In the fourth chapter, I provide an example of the organization and movement of sick and delinquent children to rehabilitative spaces away from the city in the early twentieth century. Through a glimpse into the treatment of tubercular children at the Asilo Marítimo in Mar del Plata, I show how the philanthropic ladies of the Sociedad de Beneficencia negotiated with medical professionals to define the landscape of a "healthy" childhood. I conclude by summarizing the main findings of the previous chapters and explore how concepts of children's play continued to be used to construct new ideals 
about childhood in the mid-twentieth century through examples of Peronist statesponsored constructions of civic and republican themed childhood spaces.

\section{Constructing Children's Geographies}

Childhood is a historically specific social construct in which cultural, social and economic variations exist across time and place. The hallmark 1962 work of Philippe Ariès, Centuries of Childhood: A Social History of Family Life, translated from French, acted as an important, albeit controversial, impetus to examining childhood as a social construct. Ariès posited childhood as a distinctly modern idea, which he identified in material culture around the sixteenth century and assumed could not be traced to the medieval period. ${ }^{2}$ As a result, historians, responding both in criticism and reappraisals of their understanding of the historical family in the West, reflected on childhoods across a variety of temporal and regional settings. ${ }^{3}$ Ariès' comments on the "nature" of childhood and his use of material culture to study children and childhood are of most interest to the themes of this dissertation. Ariès argues that the modern concept of childhood comes from "an awareness of the particular nature of childhood, that particular nature which distinguishes the child from the adult.”4 ${ }^{4}$ Portraits of upper class children, whose clothing began to distinguish them from adults, evidence Aries’ argument, revealing a material

2. Philippe Ariés, Centuries of Childhood: A Social History of Family Life, trans. Robert Baldick (New York: Vintage Books, 1962), 33-49.

3. A body of literature on medieval childhoods produced as a result, see for example: Shulamith Shahar, Childhood in the Middle Ages (London; New York: Routledge, 1990); Barbara A. Hanawalt, Growing Up in Medieval London: The Experiences of Childhood in History (New York: Oxford University Press, 1993); James A. Schultz, The Knowledge of Childhood in the German Middle Ages, 1100-1350 (Philadelphia: University of Pennsylvania Press, 1995) For a historiographical review on the cultural construction of childhood in history, Hugh Cunningham, "Histories of Childhood," The American Historical Review 103, no. 4 (October 1998): 1195-208.

4. Ariés, Centuries of Childhood, 128. 
change behind concepts of childhood as separate from adulthood. Ariès looks further to literary descriptions of women to describe early concepts of "coddling," whereas the child, he argues, is first imagined as "a source of amusement and relaxation for the adult." ${ }^{5}$ A second concept Ariès describes was reactionary to coddling and is expressed as "a determined attempt to turn [children] into thinking men and good Christians.”6

These two concepts converged together in family life by the eighteenth century, along with a concern over hygiene and health, to place the child at the center of family life. Ariès’ work demonstrated the significance of studying the material worlds of children, and a number of monographic works followed examining the artifacts of childhood. $^{7}$ Analyses of the material goods of childhood, like clothing, toys and furnishings, often revealed notions of idyllic childhoods. ${ }^{8}$ In large part, the consumer culture built around children's products in the eighteenth and nineteenth centuries represented the growing industrial middle classes and an increasing separation between child and adult spheres of sociability. Of course, children do not always use products as expected (or advertised), and sometimes they are used outside of their intended audience. The manipulation of children's material culture reveals insights into the social

5. Ariés, Centuries of Childhood, 129-30.

6. Ariés, Centuries of Childhood, 131.

7. Karin Calvert, Children in the House: The Material Culture of Early Childhood, 1600-1900 (Boston: Northeastern University Press, 1992); Alexander von Vegesack, Jutta Odiges, and Bullivant, eds., Kid Size: The Material World of Childhood (Milan: Skira editore, 1997); Jane Eva Baxter, The Archaeology of Childhood: Children, Gender, and Material Culture, Gender and Archaeology Series, vol. 10 (Walnut Creek, CA: AltaMira Press, 2005).

8. Steven Mintz, Huck's Raft, A History of American Childhood (Cambridge: Belknap Press of Harvard University Press, 2004). 
construction of childhood, but also the manipulation of historically specific material culture for and around children. ${ }^{9}$

Historian Daniel Thomas Cook, in his work on the American child consumer, theorized that while Ariès might not have discovered the first concepts of childhood, his theories did point to an emerging belief that children were innocent and susceptible to influence. In other words, Ariès pointed to an emerging ideology in which it was believed a child's nature could be molded or transformed, first in the home and later by the public. These ideas laid the "groundwork for a children's material, commercial culture," and Cook likens them to those of John Locke and Jean-Jacques Rousseau. ${ }^{10}$ For seventeenth century Locke, childhood development was defined by reason. Children were born as a tabula rasa and formed by the extent of their experiences and education. For Rousseau, the nature of childhood was innocent, but susceptible to corruption. For Cook, the material world of American childhood began to separate from adulthood around the late nineteenth century with wide-scale manufacturing of children's goods. ${ }^{11}$ The perception that consumer goods could transform childhood, and thus transform

9. Sally Mitchell, The New Girl: Girls' Culture in England, 1880-1915 (New York: Columbia University Press, 1995); Miriam Formanek-Brunell, Made to Play House, Dolls and the Commercialization of American Girlhood, 1830-1930 (Baltimore: The Johns Hopkins University Press, 1998); Peter N. Stearns, Anxious Parents: A History of Modern Childrearing in America (New York; London: New York University Press, 2003); Daniel Thomas Cook, The Commodification of Childhood: The Children's Clothing Industry and the Rise of the Child Consumer (Durham: Duke University Press, 2004); Catriona Kelly, Children's World: Growing up in Russia, 1890-1991 (New Haven, Conn.: Yale University Press, 2007).

10. Cook, The Commodification of Childhood: The Children's Clothing Industry and the Rise of the Child Consumer, 30.

11. Cook, The Commodification of Childhood, 22-30. 
children, formed part of a bigger discourse at play in the nineteenth century, that childhood was malleable through the environment.

Following Aries" "discovery" of childhood, scholars focused on writing the institutional history surrounding children, such as changing education and welfare policy. However often times these works did not critically examine childhood as a social category, but instead imagined childhood as having only a singular trajectory. The sociological underpinnings to the study of these institutions of childhood pointed to children as 'becomings', rather than 'beings', in a process towards adulthood. ${ }^{12}$ Critical of this approach since the 1980s, scholars reflected on the multitude of childhood experiences that existed across social, economic, racial and gender lines. A childcentered approach to research formed, often referred to as the "new sociology of childhood,” and sought to include children as active agents and participants in sociological studies. ${ }^{13}$ In order to fully understand the ideologies of childhood(s), "we also must study children themselves and take seriously their own accounts.” ${ }^{\text {,4 }}$ The new sociology of childhood, rather than viewing children as passive and incomplete 'adults in the making', placed children as active subjects in sociological research. ${ }^{15}$

12. Emma Uprichard, "Children as Being and Becomings: Children, Childhood and Temporality," Children \& Society 22, no. 4 (July 2008): 303-13.

13. Sarane Spence Boocock and Kimberly Ann Scott, Kids in Context: The Sociological Study of Children and Childhood (Lanham, Md.: Rowman \& Littlefield Publishers, 2005).

14. Suzanne Shanahan, "Lost and Found: The Sociological Ambivalence Toward Childhood,” Annual Review of Sociology 33 (2007): 419.

15. See "Introduction," Allison James and Alan Prout, eds., Constructing and Reconstructing Childhood: Contemporary Issues in the Sociological Study of Childhood (London ; New York: Falmer Press, 1990), 16; J Brannen and M O’Brien, "Childhood and the Sociological Gaze: Paradigms and Paradoxes," Sociology 29 (1995): 729-37 Some criticism questioning the "newness" of the field has led some scholars to reexamine the place of childhood studies as a sub-field in academic scholarship. See Patrick J. Ryan, 
Scholars of children and childhood in Latin America sometimes claim a late arrival into the "new" field of childhood studies. ${ }^{16}$ Yet, as historian Bianca Premo explains in the first issue of The Journal of the History of Childhood and Youth, studies of children and youth in Latin America have long historiographies, particularly in research on education, family, gender and slavery. A turn towards the explicit study of childhood and youth in the history of Latin America, she argues, was intrinsically tied to the rethinking of Latin America's processes of modernization. Within this socio-cultural turn in the study of modernization, scholarship that once examined the region's apparent economic and political failures began to examine how ideologies of modernity were produced and experimented with in the region. ${ }^{17}$ The tendency to place Latin American studies of childhood as arriving late to the field, mirrors "...Latin America's uneasy relationship to 'modernity' and its status as both part of the 'West' and one of the 'rest'..." and perpetuates in many ways, notions of dependency that have long overshadowed the history of Latin America. ${ }^{18}$

Geographer Sarah Radcliffe outlined, in the introduction of a collection of essays titled "When was Latin America Modern?” some of the problems with studies of

\footnotetext{
"How New Is the 'New' Social Study of Childhood? The Myth of a Paradigm Shift," The Journal of Interdisciplinary History 38, no. 4 (Spring 2008): 553-76.

16. Tobias Hecht, "Introduction," in Minor Omissions: Children in Latin American History and Society, ed. Tobias Hecht (Madison: University of Wisconsin, 2002), 3-20.

17. Bianca Premo, "How Latin America's History of Childhood Came of Age," Journal of the History of Childhood and Youth 1, no. 1 (Winter 2008): 68-71

18. Premo, "How Latin America’s History of Childhood Came of Age," 64.
} 
modernity in the region. ${ }^{19}$ Radcliffe argues that understandings of modernity are largely Eurocentric, imagined as the diffusion of modernity from Europe outward, and points to the important revisions being made to spatial theory to reveal how regions of Latin America experimented with and generated local concepts of modernity. ${ }^{20}$ In the field of historical geography, the significance that geographical practices have "in the construction of modernity" and the powerful discourses they produce are revealed in several ways. Radcliffe reiterates, "spaces of modernity and geographical practices lie at the center of modernity's projects, are the subject of numerous contested discourses, and underpin the embodied experiences of modernity." ${ }^{21}$ Indeed, the construction of spaces of childhood within Buenos Aires reveals a contested, spatial discourse with widely varying experiences in the production of modernity in Argentina.

There are inextricable links between the discourses of modernity, childhood and space. 'Modernity' and 'childhood' are socially constructed and negotiated spaces, and a significant part of nation-building projects. Planners, intellectuals, politicians, physicians, educators and parents, all contributed in the construction of the rapidly growing urban environments of Latin America throughout the nineteenth and twentieth centuries. Discourses on modernity, and thus childhood, were not simply diffused from Europe to Latin America, but rather were produced, experimented with, and sometimes rejected in various regions. A commonality amongst many nation-building projects in

19. Sarah A. Radcliffe, "Geographies of Modernity in Latin America: Uneven and Contested Development," in When Was Latin America Modern?, eds. Nicola Miller and Stephen Hart (New York, NY: Palgrave Macmillan, 2007), 21-4.

20. Radcliffe, “Geographies of Modernity in Latin America: Uneven and Contested Development,” 21.

21. Radcliffe, “Geographies of Modernity in Latin America: Uneven and Contested Development,” 41. 
Latin America and across the Atlantic is a development, over the course of the nineteenth century, of specialized institutions and professions dealing explicitly with children. Governments implemented an array of policies as part of the negotiation of state involvement in the everyday lives of children and families.

Childhood, examined as a tool for nation and state-building, gained momentum with the increase of women's history in Latin America, particularly through examinations of the politics of education and welfare. Patience Schell points to the Porfiriato (18761911) in Mexico as a moment of deep state involvement in the construction of childhood. Schell argues that new state policies were implemented to regulate children's lives through school and hygiene programs, constructing strong institutional ties to social control mechanisms. ${ }^{22}$ Mark D. Szuchman, in his work on education and politics, reveals elite expectations of children's roles in early nineteenth century Buenos Aires. Szuchman argues that the relationship between the state and family was transformed by increasing state involvement in children’s lives. ${ }^{23}$ Similarly, Donna Guy argues that philanthropic and feminist groups in the late nineteenth century, aimed at helping orphaned and abandoned children, provided the impetus for a "welfare state" in Argentina. ${ }^{24}$ Ann S. Blum provides another interpretation of the period in Domestic Economies: Family, Work and Welfare in Mexico City, 1884-1943. Exposing instead deep continuities during the liberal dictatorship, Blum argues welfare and education

22. Patience A. Schell, "Nationalizing Children Through Schools and Hygiene: Porfirian and Revolutionary Mexico City,” The Americas 60, no. 4 (2004): 559-87.

23. Mark D. Szuchman, "Childhood Education and Politics in Nineteenth-Century Argentina: The Case of Buenos Aires,” Hispanic American Historical Review 70, no. 1 (February 1990): 109-38.

24. Donna J. Guy, Women Build the Welfare State: Performing Charity and Creating Rights in Argentina, 1880-1955 (Durham and London: Duke University Press, 2009). 
served only to reproduce class distinctions. Despite changes in the legal definitions of childhood and increased state intervention under the rhetoric of welfare, little actually changed for the laboring classes. ${ }^{25}$

The study of children and childhood reveals important currents of continuities in Latin America, despite the practice of new "modern” nation-building policies. Nara Milanich's book Children of Fate: Childhood, Class, and the State in Chile, 1850-1930, presents a rich analysis of the history of childhood and the processes of liberal state formation in Chile. Milanich's analysis is an excellent example of childhood history in Latin America, revealing social inequalities in the face of modern state discourses of equality. Through a study of familial practices, Milanich examines how changing legal definitions of family and childhood reinforced social hierarchies, patriarchy and dependencies of gender and class. Milanich joins other scholars of Latin America who point to the traditional informal politics of everyday life to challenge legal and state power. ${ }^{26}$ Despite discourses of modernizing state development of children's welfare, typically families relied on traditional kinship ties. New welfare institutions sometimes acted as extensions of the family, encouraged as an option for the lower classes to exercise traditional child circulation rather than abandonment. ${ }^{27}$ Milanich's examination

25. Ann S. Blum, Domestic Economies: Family, Work and Welfare in Mexico City, 1884-1943 (Lincoln: University of Nebraska Press, 2009).

26. Nara Milanich, Children of Fate: Childhood, Class and the State in Chile, 1850-1930 (Durham: Duke University Press, 2009).

27. Nara Milanich, "The Casa de Huérfanos and Child Circulation in Late-Nineteenth-Century Chile," Journal of Social History 38, no. 2 (2004): 311-40; Ann S. Blum, "Public Welfare and Child Circulation, Mexico City, 1877-1925,” Journal of Family History 23, no. 3 (1998): 240-71. 
of the unique nature of child circulation between personal and public networks, transformed the way historians understand state and family relationships in the region.

This dissertation builds on the work of historians, whose research brings to light the many productions of "modernity" through the re-examination of nineteenth and twentieth century institutions of childhood. Following recent paradigm shifts in the historiography of childhood, this dissertation takes a cross-disciplinary approach to reveal how space and place intersect with the construction of childhood and the everyday lives of children. ${ }^{28}$ Children's geography is a growing sub-field of human geography and childhood studies. Rooted in questions about children's ability to map and understand space, scholars of this sub-field, increasingly since the 1990s, influenced by the new social studies of childhood, focused on giving children a voice in the negotiation and production of space. ${ }^{29}$ Of particular interest is the understanding that everyday spatialities, such as the school, playground and home, are bound by social, economic and political contexts, and reveal much about the historical experiences of children and youth. Childhood is bound by time and place, both in society and in lived spaces, and is crucial to the construction of identity. ${ }^{30}$

28. Louise Chawla, "Revisioning Childhood, Nature, and the City," Architecture and Behaviour 10, no. 4 (1994): 343-50; Marta Gutman and Ning de Coninck-Smith, "Introduction: Good to Think With - History, Space, and Modern Childhood," in Designing Modern Childhoods: History, Space, and the Material Culture of Children, ed. Marta Gutman and Ning de Coninck-Smith (New Brunswick: Rutgers University Press, 2008), 1-19.

29. Chris Jenks, Childhood (London ; New York: Routledge, 2002); Stuart C. Aitken, Putting Children in Their Place (Department of Geography: San Diego State University, 1994); Sarah L. Holloway and Gill Valentine, "Children's Geographies and the New Social Studies of Childhood," in Childhood: Critical Concepts in Sociology (London: Routledge, 2005), 163-88.

30. Sarah Holloway and Gill Valentine, eds., Children's Geographies: Playing, Living, Learning, Critical Geographies (London ; New York, N.Y.: Routledge, 2000). 
It is important to reflect on the processes of the production of space and the larger challenge to see how children make meaning in spaces as well. Henri Lefebvre acutely describes the significance of the production of space as a process, with a variety of forces shaping its meaning. Lefebvre calls for a critical Marxist examination of the production of space, to understand the powers that organize and control space, and calls for a bottom-up production of space to counter it. Mobility within or exclusion from spatial boundaries, as well as expectations of behavior or the purposeful misuse of space by children, adds to a greater understanding of their everyday lived experiences. The social production of space is contested then by 'spatial practice' or the everyday use of space. ${ }^{31}$ The city's landscape, then, is both a tool for hegemonic control and a tool for resistance.

Much like the sociological approaches to the study of childhood, scholars of the sub-discipline of Children's Geographies often point to the "new" engagements they bring to the study into the lives of young subjects. The editors of the scholarly journal Children's Geographies point to criticisms that the 2006 New Directions in Children's Geographies conference was "the same old stuff" and "so boring."32 They posed the question "Why do so many 'Children's Geographies' conferences go out of their way to promise the new?"133 The editors point to their own existence as a subfield, nested in human geography, and a lack of inter-disciplinary cooperation as part of the explanation. Children "are very often absent from broader epistemologies in Human Geography” and

31. Henri Lefebvre, The Production of Space, Donald Nicholson-Smith (Oxford: Blackwell Publishers Ltd, 1991).

32. John Horton, Peter Kraftl, and Faith Tucker, “The Challenges of 'Children’s Geographies': A Reaffirmation (Editorial Introduction),” Children's Geographies 6, no. 4 (2008): 336, 346.

33. Horton, Kraftl, and Tucker, “The Challenges of 'Children’s Geographies',” 336. 
perhaps the sub-field is "seen as sufficient in 'taking care of the kids'.”34 The many calls for broader cross-disciplinary synthesis in the study of children and childhood is, in part, a critical response to the claim of nascent sub-fields in the larger fields of sociology, anthropology, geography and history. ${ }^{35}$

There is a growing body of literature examining the historical geographies of childhood, largely focused on children and the spaces they occupy, namely the home, school and public space. ${ }^{36}$ A collection of essays, Designing Modern Childhoods: History, Space, and the Material Culture of Children (2008), provides an example of the variety of themes emerging from historical spatial analyses of children and childhoods. Authors in this collection examine the conception, construction, and use of children's built environments, including the home, schools, hospitals, parks and playgrounds. The use of space to construct social norms is explored, as well as the interplay of race and gender in the sometimes-exclusive nature of space. The editors introduce the end of the nineteenth century as a moment in time when increasing urbanization led many adults to “save children” from the industrial city, where sociologists, psychologists, architects, urban planners, parents and children all participated in the social construction of the built

34. Horton, Kraftl, and Tucker, “The Challenges of 'Children’s Geographies',” 338.

35. Joseph M. Hawes and N. Ray Hiner, "Hidden in Plain View: The History of Children (and Childhood) in the Twenty-First Century," Journal of the History of Childhood and Youth 1, no. 1 (Winter 2008): 4349; Ryan, "How New Is the 'New' Social Study of Childhood."

36. See for example, Anna Davin, Growing up Poor: Home, School, and Street in London, 1870-1914 (London: Rivers Oram Press ; Concord, MA: Paul and Company, 1996); Kristin L. Hoganson, Consumers' Imperium: The Global Production of American Domesticity, 1865-1920 (Chapel Hill: University of North Carolina Press, 2007); Sarah Holloway and Gill Valentine, Children's Geographies: Playing, Living, Learning; Joe L. Frost, A History of Children's Play and Play Environments: Toward a Contemporary Child-Saving Movement (New York: Routledge, 2010). 
environment. ${ }^{37}$ While none of the essays explore spaces of childhood in Latin America, this dissertation presents similar themes and methods of analysis.

In an essay in Designing Modern Childhoods, "Molding the Republican Generation,” Zeynep Kezer explores the role that landscape played in reforming educational institutions in early republican Turkey. Focusing on the material culture of education, Kezer argues that the "sites of learning” reveal much about modernization efforts in the nation-building process. ${ }^{38}$ Kezer reveals that studying geography, incorporating prototype designs of schools, and the use of excursions in pedagogy all reinforced social and spatial "normative orders and expectations of the society."39 These educational policies further served to indoctrinate children with republican ideals and a shared sense of the national community. In another essay on American summer camps, Abigail A. Van Slyck examines the historical "islanding” of childhood away from spaces of adulthood, first expressed by John Gillis. ${ }^{40}$ In the late nineteenth and early twentieth centuries, Van Slyck posits that summer camps reveal adult's anxieties regarding modernity and gender and that rural, natural spaces - as antithesis to modern urban space

37. Gutman and Coninck-Smith, "Introduction.”

38. Zeynep Kezer, "Molding the Republican Generation: The Landscapes of Learning in Early Republican Turkey," in Designing Modern Childhoods: History, Space, and the Material Culture of Children (2008), 128-51.

39. Kezer, “Molding the Republican Generation,” 147.

40. John R. Gillis, "Epilogue: The Islanding of Children - Reshaping the Mythical Landscapes of Childhood," in Designing Modern Childhoods: History, Space, and the Material Culture of Children, ed. Marta Gutman and Ning Coninck-Smith (New Brunswick: Rutgers University Press, 2008), 316-30. 
- provided a place to define "natural” childhood. ${ }^{41}$ Similarly to Europe and North

America, Latin American republics experimented with and produced new spaces

exclusively for children at the turn of the nineteenth century. While the field of

geography is adding to our understanding of the place of childhoods in Latin America,

much of the literature examining spaces of childhood are contemporary in nature and

focuses on so-called street children. ${ }^{42}$ Literature examining the history of spaces of

childhood, as a historically specific, social construction, is still considerably lacking in

Latin American historiography. ${ }^{43}$

At least since the 1980s, historians of Latin America have explored how space

and the organization of spatial structures are central to lived experiences. ${ }^{44}$ Urban

historical studies of Latin American cities boomed in the 1960s, largely reflecting

attempts to explain the growth of Latin American cities and the associated contemporary

problems that arose from rapid expansion. Scholarship largely viewed Latin America as

41. Abigail A. Van Slyck, "Connecting with the Landscape: Campfires and Youth Culture at American Summer Camps, 1890-1950," in Designing Modern Childhoods: History, Space, and the Material Culture of Children (2008), 23-41.

42. Elizabeth Kuznesof, "The House, the Street, Global Society: Latin American Families and Childhood in the Twenty-First Century,” Journal of Social History, Summer 2005, 859-72; Saundra Lauderdale Graham, House and Street: The Domestic World of Servants and Masters in Nineteenth-Century Rio de Janeiro (Cambridge: Cambridge University Press, 1988); Tobias Hech, At Home in the Street: Street Children of Northeast Brazil (Cambridge University Press, 1998).

43. Some notable exceptions: Lauderdale Graham, House and Street: The Domestic World of Servants and Masters in Nineteenth-Century Rio de Janeiro; Alberto del Castillo Troncoso, "Entre la Criminalidad y el Orden Cívico: Imágenes y Representaciones de la Niñez Durante el Porfiriato,” Historia Mexicana (1998); Alberto del Castillo Troncoso, "Imágenes y Representaciones de la Niñez en México en el Cambio del Siglo XIX al XX,” Cuicuilco. Revista de la Escuela Nacional de Antropología e Historia 10, no. 29 (2003): 141-68; Julio Césad Ríos and Ana María Talak, La Niñez en los Espacios Urbanos (Taurus, 2002).

44. Edward W. Soja, Postmodern Geographies: The Reassertion of Space in Critical Social Theory (London: Verso, 1989) For a concise introduction to the "spatial turn" in the humanities, Barney Warf and Santa Arias, "Introduction: The Reinsertion of Space Into the Social Sciences and Humanities," in The Spatial Turn: Interdisciplinary Perspectives, ed. Barney Warf and Santa Arias (New York: Routledge, 2009), 1-10. 
a region of failed economies, overly dependent on exports and plagued by overcrowded urban centers. ${ }^{45}$ Efforts to examine broader socio-economic processes in the 1970 s led to reinterpretations of cities’ spatial growth, and scholars examined demographic growth, urban development and sprawl as they affected social groups beyond the economic elite. ${ }^{46}$ How these processes of change in cities were related to larger processes of the state was also considered. Increasingly, quantitative analyses revealed patterns of migration, class conflict and social mobility. ${ }^{47}$ Spatial analyses stood at the forefront of these works, intersecting processes involved in city planning, architecture and technological change. Material culture and representations of urban culture through

45. Richard M. Morse, “Trends and Issues in Latin American Urban Research, 1965-1970,” Latin American Research Review 6, no. 2 (Summer 1971): 19-75; Jorge Balan, Harley L Browning, and Elizabeth Jelin, Men in Developing Society; Geographic and Social Mobility in Monterrey, Mexico (Austin: University of Texas Press, 1973); Richard M. Morse, "Trends and Patterns of Latin American Urbanization, 1750-1920," Comparative Studies in Society and History 16, no. 4 (September 1974): 41647; Oscar Yujnovsky, Notes on Research on the Urban Spatial Configuration and Land Use Policies in Latin America (Austin: University of Texas Press, 1974); Jorge Hardoy, ed., Urbanization in Latin America: Approaches and Issues (Garden City, NJ: Anchor Books, 1975); Rolando Mellafe, "Review: Urban Studies: A Bibliographic Explosion,” Journal of Interamerican Studies and World Affairs 17, no. 1 (February 1975): 101-08; Alejandro Portes and Harley L Browning, eds., Current Perspectives in Latin American Urban Research (Austin: University of Texas Press, 1976); John Walton, "From Cities to Systems: Recent Research on Latin American Urbanization,” Latin American Research Review 14, no. 1 (1979): 159-69; Eugene F. Sofer and Mark D. Szuchman, "City and Society: Their Connection in Latin American Historical Research,” Latin American Research Review 14, no. 2 (1979): 113-29.

46. Richard M. Morse, From Community to Metropolis: A Biography of São Paulo, Brazil (Gainesville: University of Florida Press, 1958); James R. Scobie, Buenos Aires: Plaza to Suburb, 1870-1910 (New York: Oxford University Press, 1974); José Luis Romero, Latinoamérica: Las Ciudades y las Ideas (Mexico City: Siglo veintiuno, 1976); Charles S Sargent, The Spatial Evolution of Greater Buenos Aires, Argentina, 1870-1930 (Center for Latin American Studies: Arizona State University, 1971).

47. Ronald Newton, German Buenos Aires, 1900-1933: Social Change and Cultural Crisis (Austin: University of Texas Press, 1977); Mark D Szuchman, Mobility and Integration in Urban Argentina: Córdoba in the Liberal Era (Austin: University of Texas Press, 1980); Eugene F. Sofer, From Pale to Pampa: A Social History of the Jews of Buenos Aires (New York: Hill and Wang, 1982); Benedict Anderson, Imagined Communities : Reflections on the Origin and Spread of Nationalism (London: Verso, 1983); G Marcus and M Fisher, "A Crisis of Representation in the Human Sciences and Ethnography and Interpretive Anthropology," in Anthropology as Cultural Critique: An Experimental Moment in the Human Sciences (Chicago: University of Chicago Press, 1986), 7-44. 
literature, film, fine arts and education further revealed nuances in the connections between economic, political and social contexts. ${ }^{48}$

Anton Rosenthal's historiographical essay on public space in Latin America demonstrates the benefits of placing space at the forefront of analysis of cities in Latin American history. He notes that while Latin America has retained much of its public space, critics of North American cities often point to the decline of public space and the loss of social gathering places after World War II. In fact, many aspects of Latin American cities have helped to protect public space, including its plaza-centered grid plans, public transportation systems, and its integration of local histories into public spaces. In addition, urban culture of Latin America supports public socialization, with its cafe-oriented culture and supporting concepts of time management. This is often juxtaposed to a North American culture of social exclusion and long workday habits. ${ }^{49}$

Recent scholarship has focused particularly on public spaces of protest and class struggle in Argentina since the 1940s. For example, Daniel James's analysis of mass protests under Peronism led him to argue that mass politics originated in the class struggles for urban space in the 1940 s. $^{50}$ Certainly, the 1955 shelling of the Plaza de

48. Mauricio Tenorio-Trillo, Mexico at the World's Fairs: Crafting a Modern Nation (Berkeley: University of California Press, 1996); John Lear, "Mexico City: Space and Class in the Porfirian Capital, 1884-1910," Journal of Urban History 22, no. 4 (May 1996): 454-92; David William Foster, Buenos Aires: Perspectives on the City and Cultural Production (Gainesville: University Press of Florida, 1998); José C. Moya, Cousins and Strangers: Spanish Immigrants in Buenos Aires, 1850-1930 (Berkeley: University of California Press, 1998); Samuel L Baily, Immigrants in the Lands of Promise: Italians in Buenos Aires and New York City (Ithaca, NY: Cornell University Press, 1999); Mary K Vaughan and Stephen Lewis, The Eagle and the Virgin: Nation and Cultural Revolution in Mexico, 1920-1940 (Durham: Duke University Press, 2006).

49. Anton Rosenthal, "Spectacle, Fear, and Protest: A Guide to the History of Urban Public Space in Latin America,” Social Science History 24, no. 1 (2000): 33-73.

50. Daniel James, Resistance and Integration: Peronism and the Argentine Working Class, 1946-1976, Cambridge Latin American Studies (Cambridge ; New York: Cambridge University Press, 1988). 
Mayo foreshadowed restrictions on public access to spaces of protest. Others, such as Diana Taylor, have focused on the repressive politics of the 1960s and its relationship to public space. Taylor examined Las Madres de la Plaza de Mayo and their use of the public plaza in resistance to state sponsored terrorism during the military's self described "Dirty War". Las Madres extended their motherhood as a political platform to effectively protest the state and demand information about their disappeared children. ${ }^{51}$

The concern over the loss of public access to space in the 1950s and the 1960s requires a deeper examination of the relationship between public space and everyday life prior to this time period. John R. Gillis discusses the tendency towards "islanding” childhoods, the tendency to insulate children's spaces from adult spaces, throughout the twentieth century. ${ }^{52}$ Often citing American or European childhoods, scholars bemoaning the commercialization and privatization of public space often leave Latin American childhoods out of the analysis. There needs, then, for the formation of a Latin American response to western notions of the place of childhood in the historical construction of space. Especially amongst the vast transformations of urban space at the turn of the nineteenth century, Latin American republics produced spaces exclusively for children and experimented with the construction of childhood through those spaces.

\section{The City as Playground}

Argentina's fin de siècle presented Buenos Aires as the embodiment of its new Atlantic-oriented spirit, transformed by 1910, the centennial of its independence, from the

\footnotetext{
51. Diana Taylor, Disappearing Acts: Spectacles of Gender and Nationalism in Argentina's "Dirty War" (Durham and London: Duke University Press, 1997).

52. Gillis, "The Islanding of Children.”
} 
village metaphor - the "gran aldea" - to the cosmopolitan analog, the "Paris of South America."53 In 1880, the federalization of Buenos Aires as capital of the republic marked its importance as representative of the new nation-state run by an idealist elite, known as the Generación del Ochenta. How the nation would be defined, however, continued to be a point of contention well into the twentieth century. ${ }^{54}$ The city of La Plata, constructed in 1882 as the new capital of the province of Buenos Aires, separated the provincial leaders from the nation's capital. The planned city of La Plata embodied many characteristics of grid-model modern metropolises, with a plethora of designated green spaces and plazas. Serving as an idyllic construction of city-life, La Plata set the standard for many of the aspirations and transformations that would take place in Buenos Aires.

The city of Buenos Aires experienced tremendous expansion after 1880. Throughout the nineteenth century, urban expansion moved gradually, while 1880 to 1910 marked the period of most rapid expansion. Significant demographic and economic growth met with fast-paced urban development. European immigrants, attracted to the opportunities of economic prosperity and upward social mobility, contributed to a boom

53. The term Gran Aldea comes from the 1882 titled literary series about the burgeoning city of Buenos Aires: Lucio Vicente López, La Gran Aldea: Costumbres Bonaerenses (Buenos Aires, 1908) The term "Paris of South America" actually was used for a number of cities in South America in the late nineteenth century, but by 1910 the city of Buenos Aires was hailed by travelers for its high life in the "Paris of South America." Frank George Carpenter wrote many travelogues from South America, and in a compilation declared both Buenos Aires and Montevideo the "Paris of South America," see: Frank George Carpenter, South America: Social, Industrial, and Political (New York: Western W. Wilson, 1900), 316, 457; Also see reference to Caracas as the "Paris of South America," see: Richard Harding Davis, Three Gringos in Venezuela and Central America (New York: Harper \& Brothers, 1896), 221.

54. A cultural nationalist movement in the first decades of the twentieth century challenged these efforts initially. Jean H Delaney, "Imagining El Ser Argentino: Cultural Nationalism and Romantic Concepts of Nationhood in Early Twentieth-Century Argentina," Journal of Latin American Studies 34, no. 3 (August 2002): 625-58. 
of demographic growth experienced in the city. ${ }^{55}$ Census reports show the population more than doubled from 1895 to 1914, growing from 700,000 to 1.5 million. British capital flowed into Argentina, expanding the railroad system and contributing greatly to the expansion of the city and transformation of the nation's landscape. ${ }^{56}$ Technological advancement and an influx of European industrial goods were exchanged for Argentina's agricultural goods, providing the capital to put forth a series of public works projects that would further transform the urban fabric of Buenos Aires. ${ }^{57}$ The historic center of the once viceregal capital, since 1580, served as the core from which the city would rapidly expand. The process of constructing the capital to serve the needs of the new national administration included many aspects, from public works projects seeking to improve health and hygiene to rebuilding the historical center to house the new government. ${ }^{58}$ These projects were coupled with the expansion of education and the construction of schools, the creation of new spaces of sociability and recreation, and the enactment of new social and cultural policies marked to modernize the city of Buenos Aires and consolidate the nation under a unified identity. ${ }^{59}$ Among the many goals of the late

55. James R Scobie, "Buenos Aires as a Commercial-Bureaucratic City, 1880-1910: Characteristics of a City's Orientation,” The American Historical Review 77, no. 4 (October 1972): 1035-73; Moya, Cousins and Strangers: Spanish Immigrants in Buenos Aires, 1850-1930; Samuel L Baily, Immigrants in the Lands of Promise: Italians in Buenos Aires and New York City.

56. James R. Scobie, Buenos Aires; Sargent, The Spatial Evolution of Greater Buenos Aires.

57. Jeremy Adelman, Republic of Capital: Buenos Aires and the Legal Transformation of the Atlantic World (Stanford: Stanford University Press, 1999).

58. Ramón Gutiérrez, "BuenosAires, A Great European City,” in Planning Latin America's Capital Cities, 1850-1950, ed. Arturo Almandoz (London: Routledge, 2002), 50-55.

59. Mark D. Szuchman, "Constructing the City, Constructing the State: Architecture and Political Transition in Urban Argentina, 1810-1860," in State and Society in Spanish America During the Age of Revolution, Victor M. Uribe-Uran (Wilmington, DE: Scholarly Resources Inc., 2001), 193-218. 
nineteenth century, liberal elites sought to unify the new masses of Buenos Aires, assimilate immigrants under a common identity, and institutionalize community through the construction of a public common heritage. ${ }^{60}$ These processes included planning an urban landscape to bind the public under a shared, albeit controlled, space. Buenos Aires, thus, became a playground to experiment with ideologies of modernity and nationhood. The state's goal to homogenize the population brought public space and childhood to the core of discourse on urban planning, and the state acted under the auspices of education, socialization, health and hygiene to increase its presence in the everyday lives of its population. ${ }^{61}$ The institutionalization of childhood, an integral part of nation-state building, shared in transforming the spaces of the city by the turn of the century. Public space also served a growing state apparatus to indoctrinate the masses with a new sense of Argentinidad. ${ }^{62}$

In many ways public space, established as an integral component of sociability in Buenos Aires, acted as a classroom for the state to establish a national story of its development and assimilate new immigrant families under a common Argentine identity. State and city planners developed a variety of projects to inject a specific historical story and Argentinidad into public space and public life. Planning efforts to construct public spaces of familial instruction transformed the landscape of Buenos Aires to include

\footnotetext{
60. Samuel L. Baily, "Marriage Patterns and Immigrant Assimilation in Buenos Aires, 1882-1923," Hispanic American Historical Review (1980).

61. Mark D. Szuchman, "Raising the Nation: Childhood, Education, and the State in Nineteenth- and Twentieth Century Latin America,” American Historical Association (2007); Hobart A. Spalding Jr., "Education in Argentina, 1890-1914: The Limits of Oligarchical Reform," The Jornal of Interdisciplinary History 3, no. 1 (Summer 1972): 31-61.

62. Nicolas Shumway, The Invention of Argentina (Berkeley: University of California Press, 1991).
} 
spaces of selective historical preservation, specific nomenclature of streets and plazas, and the establishment of public civic activities to consolidate identity formation. Public space, however, did not remain static, as revealed by the many transformations that took place in the second half of the nineteenth century by porteño elite ideologues. At the turn of the century, modernity and nationhood as defined by the liberal central elites came under fire, and public spaces provided the stage for contesting and negotiating Argentina's identity. ${ }^{63}$

The federalization of Buenos Aires in 1880 marked the consolidation of the newly centralized state, and the promise of a break from the civil unrest that had gripped the country throughout the nineteenth century. Planners inscribed a national story and a sense of Argentinidad into the city's plazas, parks and streets. Often commemorating actors in the independence movement, the fall of Juan Manuel de Rosas and the newly established federal government, nomenclature provided symbolic representation and a constant reminder of a constructed historical memory. Plaza Intendente Alvear, for example, commemorated the mayor Torcuato Alvear, responsible for undertaking major public works projects and reshaping the urban fabric of the city in the 1880 s. ${ }^{64}$ Plaza Once de Setiembre served as a reminder of the revolution of 1852 leading to the secession of the province of Buenos Aires from the Confederation of Argentina. ${ }^{65}$

63. Hilda Sabato, "Citizenship, Political Participation and the Formation of the Public Sphere in Buenos Aires 1850s-1880s," Past and Present Society 136, no. 1 (1992): 139-63; Jeffrey D. Needell, "Rio de Janeiro and Buenos Aires: Public Space and Public Consciousness in Fin-de-Siecle Latin America," Comparative Studies in Society and History 37 (1995): 519-40. Rosenthal, "Spectacle, Fear, and Protest: A Guide to the History of Urban Public Space in Latin America."

64. Adolfo P. Carranza, Razón del Nombre de las Plazas, Parques y Calles de la Ciudad de Buenos Aires (Buenos Aires: Litografia É Imprenta O. Kraft, 1895), 7.

65. Carranza, Razón del Nombre de las Plazas, Parques y Calles, 9. 
Avenida Sarmiento, named in honor of Domingo F. Sarmiento, commemorated the educator and minister of the State whose influence is so often credited for the urban transformations of the late nineteenth century. ${ }^{66}$ Nomenclature served as one tool for inscribing historical memory and instilling a sense of specific unified national origin.

\section{The Urban Open Landscape}

Public space, historically, acted as the stage for the elite to construct idealized notions of society, and reformists of the late-nineteenth imbedded modern notions of society within public spaces. Statues and plaques served as obvious visual representations, but open green space served as a symbol for urban metropolises of health, education, morality and equality in the modern world. ${ }^{67}$ Improving the urban environment, in fact, was a tenet of modernity across the Atlantic world, and the leading intellectuals of the time perpetuated that a healthy, green environment was the key to improving quality of life and quality of character. Indeed, professionals argued the unhealthy environment caused numerous social and physical ailments, from crime and immorality to poverty and disease. ${ }^{68}$ It is under this precedent, that the environment becomes an important point of analyses.

66. Carranza, Razón del Nombre de las Plazas, Parques y Calles, 87.

67. Anderson, Imagined Communities : Reflections on the Origin and Spread of Nationalism; E.J. Hobsbawm, Nations and Nationalism Since 1780: Programme, Myth, Reality (Cambridge [England: Cambridge University Press, 1992); Shumway, The Invention of Argentina.

68. For more on the "pathogenic" nature of the city at the turn of the nineteenth century, see: Kindon T. Meik, "Disease and Hygiene in the Construction of Nation: The Public Sphere, Public Space, and the Private Domain in Buenos Aires, 1871-1910,” Ph.D. diss., FIU Electronic Theses and Dissertations Paper 547 (2011) (Florida International University), Http://digitalcommons.fiu.edu/etd/547; Diego Armus, The Ailing City: Health, Tuberculosis, and Culture in Buenos Aires, 1870-1950 (Durham and London: Duke University Press, 2011); Donna J. Guy, Sex and Danger in Buenos Aires: Prostitution, Family, and Nation in Argentina (Lincoln: University of Nebraska Press, 1991); Andrew Lakoff, "The Simulation of Madness: Buenos Aires, 1903,” Critical Inquiry 31, no. 4 (Summer 2005): 848-73. 
The Argentine state’s "scientific” approach to modernization and progress, resonant with the belle époque in Europe, contributed to changes in public space and landscape as well. At the same time that public spaces were expanded, so too did efforts to establish an ordered, hygienic landscape result in projects to cope with the rapidly expanding immigrant population, perceived by the upper classes as a significant cause of urban social problems. President Domingo Sarmiento (1868-1874) encouraged the development of schools and parks as fundamental to the political process of uniting and civilizing the nation. Sarmiento encouraged state interest in both childhood and public space. Though national projects continued to be built on the discourse of unification, a historical trope of the nation's turbulent experience, it did little to prevent the exclusion of groups deemed "unhealthy” from the city’s public spaces. The scientific progressive era of urbanization, in many ways, lent itself to segregation. Just as hospitals in the late nineteenth century constructed new isolation wings to avoid spreading infectious diseases, the city's spaces were segregated to contain perceived urban problems.

The capital city of Buenos Aires indeed holds a rich and contested history within its landscape. Cartographic representations of Latin America, during and after colonial rule, reveal the crucial role that geography played in both mapping out boundaries and spatially linking populations to place and collective identity in the nineteenth century. Planning and constructing the new capital city of Buenos Aires in the late nineteenth century reveals the culmination of a highly contested nature of place making and nineteenth century nation building. The processes of urban change reveal a complex cultural evolution of city planning and nation-building. Analyses of the development of space and place and its many discourses provide significant points for historians to 
uncover the complexities of social constructions, the imagined and real geographies that make place and give meaning to space.

During Argentina’s fin de siècle, a moment between 1880 and 1910 of deep social and cultural change, a rich history is revealed through the transformations of the city's public spaces. The historical socio-political significance of public space in Latin America's cities is well documented, and this is particularly true of urban squares and plazas, etched out in the early colonial era and then re-imagined in the nineteenth and twentieth centuries. ${ }^{69}$ Mapping and regimenting space was integral to the processes of early Spanish colonization, particularly in the subjugation and control of indigenous populations. The plaza served as the heart of urban colonial centers, modeling Spanish policía in a construction of Spanish colonial idealism. ${ }^{70}$ The processes of organizing space continued well after independence, as nation-states spent the better part of the nineteenth century mapping and defining national boundaries. By the last decades of the nineteenth century in Argentina, cartography not only served to demonstrate its national

69. For example, see: Meik, "Disease and Hygiene in the Construction of Nation”, Jeffrey D. Needell, "Rio de Janeiro and Buenos Aires: Public Space and Public Consciousness in Fin-de-Siecle Latin America," Comparative Studies in Society and History 37 (1995): 519-40; Rosenthal, "Spectacle, Fear, and Protest: A Guide to the History of Urban Public Space in Latin America"; Victor M. Uribe-Uran, "The Birth of a Public Sphere in Latin America During the Age of Revolution," Comparative Studies in Society and History 42, no. 2 (April 2000): 425-57 (Cambridge University Press); Meik, "Disease and Hygiene in the Construction of Nation."

70. Spanish policía refers to urban order and governance in the colonies, often linked to the control, segregation and monitoring of the indigenous populations. Read more about the relationship between urbanity and the Spanish colonial project in: María Elena Martínez, "Space, Order and Group Identities in a Spanish Colonial Town: Puebla de los Angeles," in The Collective and the Public in Latin America: Cultural Identities and Political Order, ed. Luis Roniger, Tamar Herzog (Brighton: Sussex Academic Press, 2000), 13-20. 
boundaries externally, but also further included, in public education, curricula of geography to construct and consolidate a shared national identity internally. ${ }^{71}$

In the city of Buenos Aires, the centralized national government of the late nineteenth century sought to construct a new national ideal, transforming the public square, and removing and replacing colonial structures and architecture. Similarly to the colonial period, however, ruling elites imagined an ordered, more civilized society, pushing perceived social ills to the periphery. The public square, still significant, expanded in urban centers. A conscientious effort to improve health and unify the population under one nation, led to the development of new public spaces, including vast green parks, plazas and playgrounds. Yet discourse between civilization and barbarism appeared in the nineteenth century similarly as it did in the sixteenth, whereas spatial distinctions tended to separate rather than unite. This went beyond the rural-urban divide, as cities too increasingly divided along socio-economic lines and often alongside patterns of industrial change. ${ }^{72}$

One of the most praised aspects of late nineteenth century city planning in Buenos Aires was the massive project to provide green landscapes throughout the city. The construction and landscaping plans of public parks were part of the grandeur plan to unify the nation under a common identity, as well as present the city to the Atlantic world. These new public spaces were admired as significant cures to perceived social and moral

71. See, for example, the ways cartography was used as a tool in Argentina's modernization projects in Carla Lois, "Measuring Up and Fitting In," in Mapping Latin America, ed. Jordana Dym and Karl Offen (Chicago and London: The University of Chicago Press, 2011), 163-67.

72. Bryan R. Roberts, “Globalization and Latin American Cities," International Journal of Urban and Regional Research 29, no. 1 (March 2005): 118. 
ills. Late nineteenth and early twentieth century planners imagined a well-planned urban environment provided little space for disease, crime and immorality. Remarking on the newly constructed public buildings, parks and avenues in Buenos Aires at its centennial celebration of 1910, Englishman W. A. Hirst stated, “...as is always the case, [these improvements] were most beneficial to public order and safety, for narrow streets and decayed houses are nurseries of crime."73

Although the Atlantic scene typically praised the material transformations of Buenos Aires and touted the modernized city as a European metropolis in South America, dissent and criticism developed from within Argentina. At the turn of the century, Manuel Bilbao, writing the history of Buenos Aires, described these transformations taking place in the final decades of the nineteenth century. Lamenting over the lack of public plazas and gardens before 1880, he explained it was not until the population realized the benefits of green "oases” provided for health that the city began to construct them. Despite expansions in public plazas after 1880, Bilbao criticized the monuments and statues littered throughout them. He explained that the heroes of independence were almost forgotten because they were not commemorated in statues and monuments in the city, though they were still present outside the city. The political passion of the moment, he suggests “explains the statues of Mazzini, Lavalle, Alsina, Sarmiento” in the Capital. The present social, economic and political context transformed the nomenclature of plazas and monuments. Spaces that once celebrated the 1808 victory over the English invasion were transformed, as Bilbao pointed out, perhaps to allow them to be forgotten

73. W. A. Hirst, Argentina: The South American Series (London: T. Fisher Unwin, 1910), Loc. 2206 of 5041 Kindle Version. 
in light of their economic investment. The Plaza de la Fidelidad, named in honor of the liberated Africans, Mestizos and Indigenous that formed a free-corps against the English invasion in 1806, was renamed Plaza del General Belgrano, after Manuel Belgrano, a criollo revolutionary in the wars for independence. ${ }^{74}$ Selective history etched into the city's spaces reveal the new national aspirations of the late nineteenth century, as well as the exclusion and lack of space for those that did not fit the newly imagined Argentine identity.

The scope of urban transformation widened drastically alongside demographic change. Railroads and streetcars facilitated the movement of goods and people from Buenos Aires to the interior, expanding the limits of the historic city. Colonial homes near the center and in the southern district were transformed to meet housing needs of a growing immigrant population. These large homes, split for multiple families, turned once extravagant family rooms into collective patios. Overpopulation of these buildings led to entire families occupying each room in tenement style housing known as conventillos. ${ }^{75}$ Transformations were taking place outside the city as well. Military expeditions pushing the indigenous population out of the pampas culminated with the "conquest of the desert" in $1880 .{ }^{76}$ The movement to extinguish the indigenous

74. Criollo is a colonial social class term in Latin America to define people born in the Americas but with Spanish ancestry. Manuel Bilbao, Buenos Aires Desde Su Fundación Hasta Nuestros Días (Buenos Aires: Imprenta de Juan A. Alsina, 1902), 557-59.

75. Ramón Gutiérrez, "Buenos Aires, A Great European City,” in Planning Latin America’s Capital Cities 1850-1950, ed. Arturo Almandoz (London; New York: Routledge, 2002), 48-49.

76. Miguel Alberto Bartolomé, “Los Pobladores Del’ Desierto’ Genocidio, Etnocidio y Etnogénesis en la Argentina,” Cuadernos de Antropología Social 17 (2003): 162-89; Bartolomé, “Los Pobladores Del’ Desierto’ Genocidio, Etnocidio y Etnogénesis en la Argentina." 
population was a significant part of the porteño elite’s definition of Argentinidad, as a modern "civilized" population stridently overcoming "barbaric” traditions.

The defining imaginary between the barbaric and the civilized played out in contexts beyond the urban and rural dichotomy. Establishing Buenos Aires as a model of modernity in the new Argentina led to a number of projects to inscribe a unified national story within its public space. Mid-century aspirations to reorganize the central locations around the port, and relocate the wealthiest families to new homes away from the commercial zones were realized by the end of the nineteenth century. A yellow fever epidemic broke out in 1871 and provided the impetus for a mass exodus and subsequent reorganization of the population of Buenos Aires. Speculation that overcrowded conventillos and unsanitary conditions caused the spread of the epidemic, coupled with the first outbreak occurring in the area of La Boca, pushed the population to retreat from the city and stigmatized the southeastern region. It is estimated that nearly half the population fled the city. ${ }^{77}$ Urban hygiene provided a palatable discourse for state actors to act on modernization projects in Buenos Aires. Ideologically, discourse on hygiene encompassed a wide arena to transform the city's spaces and its population, to construct both an ideal environment and an ideal society.

Diego Armus, in his examination of tuberculosis in the late nineteenth century, links efforts to eradicate tuberculosis to the nineteenth century ideals of urban modernization. Tied to discourse on hygiene, reformers sought to reorder the city in the prevention of both disease and perceived social ills caused by urban growth. Green

77. James R. Scobie, Buenos Aires, 11, 124. 
spaces were presented as significant solutions to solving urban problems, like tuberculosis, viewed primarily as a social concern. Parks and plazas provided sanitary, civilizing spaces to act out idealized notions of urbanity, assimilation and education. ${ }^{78}$ Similarly, discourse on childhood was intrinsically tied to these hygiene and urban reform efforts. Amongst vast transformations in the last quarter of the nineteenth century to provide green spaces to the city of Buenos Aires, calls to provide parks and plazas accessible to masses of immigrant children provided a place for the state to etch out an ideal childhood and expand its reach into family life.

Despite the best intentions of Sarmiento and Avellaneda to transform the masses and build a more egalitarian unified nation through Buenos Aires’ sweeping green spaces, the city remained socio-economically segregated, particularly along the northsouth divide and well into the twentieth century. ${ }^{79}$ Not only was it difficult to reach the lush green parks from the southern periphery of the city, but also even as transportation networks improved, the costs of transportation made it difficult for most of the population of the periphery to utilize. By the turn of the century, criticism of the lack of public space for recreation and socialization for the masses developed into a call for more accessible parks and plazas in the southern periphery. Coupled with increasing state efforts to control the spread of perceived immoralities of the urban poor, calls for reform led to a concerted effort to provide more accessible public spaces for the masses of Buenos Aires,

78. See "The Fight against Tuberculosis and the Culture of Hygiene,” in Diego Armus, Health, Tuberculosis, and Culture in Buenos Aires, 1870-1950 (Durham and London: Duke University Press, 2011), Amazon Kindle E-Book.

79. Pedro Pírez, "Buenos Aires: Fragmentation and Privatization of the Metropolitan City," Environment and Urbanization 14, no. 1 (April 2002): 146-47. 
often in the name of childhood. Socio-spatial inequality made visible stark contrasts between the wealthy and the poor, while efforts to segregate the civilized from the barbaric clouded idealized notions of a unified city and nation. Distrust in the perceived deficiencies of private family life, further spurred state efforts to create and control a public sense of sociability among the socio-economic lower classes. An examination of the state's increasing involvement in children's lives reveals a marked socio-spatial response to real and imagined unhealthy environments.

Cities acted as playgrounds for nineteenth and twentieth century planners, reformers and politicians to generate and experiment with ideologies of childhood, modernity and nationhood. In Latin America, newly independent nation-states developed civilizing practices aimed at children, projects that increasingly intruded the long-held private tradition of family life. The tremendous pace at which urban environments grew demographically in the late nineteenth century brought new demands for childhood space, for education, health and sociability. Childhood, thus, acted as a contested ideological space, constructed and negotiated within urban landscapes. Contributing to the historicization of the child's place in the built environment, this dissertation reveals the ways in which spatial analyses provide unique insights into the development of children and childhood as a project for Latin American nation-building. 


\section{CHAPTER II}

\section{LEARNING THROUGH PLAY}

\section{A Kindergarten Age}

American children's author, Hezekiah Butterworth, in a late nineteenth century New York article, applauded the former President of Argentina, Domingo Faustino Sarmiento (1868-1874) for his tremendous influence as "the great apostle of South American education,” and his regard for "the primary school [as] the foundation of national character." 80 The benefit of growing the kindergarten movement throughout the Americas, Butterworth expounded, was that it cultivated an ethos of self-governance. Critical of the monarchical pedagogy of the past, he declared, “A kindergarten age is at hand... It will be an evolution of education, whose salutary effect is likely to be felt in the three Americas. It has already begun." ${ }^{1}$ The "kindergarten age,” celebrated by this Progressive children's author, originated with the founder of the first kindergarten, Friedrich Froebel, a scholar of German philosophy and pedagogy. This modernizing educational institution, founded in 1837 for children aged four to six, shaped efforts in early childhood development around the globe through a new play-centered pedagogy. ${ }^{82}$ The kindergarten starkly contrasted traditional methods of learning through reading

80. Hezekiah Butterworth, “The Kindergarten Age,” The Review of Reviews 14, no. 6 (December 1896): 681.

81. Butterworth, “The Kindergarten Age,” 683-84.

82. Ann Taylor Allen provides a detailed analysis of the political and cultural implications of Friedrich Froebel's kindergarten in Germany. Particularly interesting is how the kindergarten connected to early women's rights movements, elevating the status of female professional teachers, while also freeing mothers from the domestic environment. Ann Taylor Allen, "Children Between Public and Private Worlds: The Kindergarten and Public Policy in Germany, 1840 - Present,” in Kindergartens and Cultures: The Global Diffusion of an Idea, ed. Roberta Wollons (New Haven, CT: Yale University Press, 2000), 16-41. 
textbooks and memorization, favoring instead methods of pedagogical instruction that emphasized sensory development, exploration and discovery. Froebel redefined the "nature” of childhood education positing that children developed best through play activities that allowed them to experience and take in the material world around them.

Froebel's pedagogy further emphasized the earliest introduction of education to children in order to shape childhood based on German idealist philosophy. According to historian Ann Taylor Allen, Froebel’s kindergarten idea confronted “public/private boundaries that defined political as well as family life” in Germany. ${ }^{83}$ Kindergartens $^{\circ}$ challenged the private world of early childhood, traditionally rooted in the domestic space of family life. Froebel and other German nationalists considered early childhood a public concern, one in which kindergartens could act as a space to integrate both mothers and children into an ideal public life. Unlike its widespread acceptance in other parts of the world, these challenges to familial boundaries ultimately limited the spread of kindergartens in Germany. ${ }^{84}$

Deeply religious in nature, Froebel believed all things were connected in harmony to God. His pedagogy reflected a desire to guide early childhood through methods of self-discovery, by learning about nature, society and God through individual experiences. Froebel believed that infants appropriated everything around them, and "for this reason even this first stage of man's development is beyond all description important for man’s

83. Ann Taylor Allen, “Children Between Public and Private Worlds,” 17.

84. Allen details the history of German kindergartens and notes that the insistence by proponents to separate "functions of the family and school" ultimately contributed to its failure. Ann Taylor Allen, "Children Between Public and Private Worlds," 16-37. 
present and future. ${ }^{85}$ This placed maternal care at the beginning of a child's education, elevating the status of women in many ways. Froebel believed that mothers were the first teachers in a child's life and early on, he conceived his methods to be used by mothers in the home. Froebel also encouraged the training of women to be teachers, because he believed their natural role was to nurture children's development. Not only did these ideas contribute to a drastic shift worldwide of opening the public profession of teaching to women, but it also provided an integral argument for the education of young girls. Kindergartens and other early childhood institutions aided in the imagined ideal educator as that of a maternal figure, therefore requiring the training of girls for their future roles as mothers and educators of children. ${ }^{86}$

Influenced by his own early interactions with nature as a forester's apprentice, Froebel emphasized play environments and pedagogy rooted in interaction and harmony with nature. These influences inspired Froebel's methods, which included a style of learning through doing. He promoted various materials and activities for children to discover - and learn - how the world functioned. The developments of physical, spiritual and intellectual aspects of the child were emphasized through physical exercise and the manipulation and exploration of various materials. Froebel described the main materials

85. Friedrich Froebel, The Education of Man, Josephine Jarvis (New York: A. Lovell \& Company, 1885), 15.

86. For more on the influence of maternalism and early childhood education in the nineteenth century, see Ann Taylor Allen, "Spiritual Motherhood: German Feminists and the Kindergarten Movement, 18481911," History of Education Quarterly 22, no. 3 (Autumn 1982): 319-39; Jane Read, “Froebelian Women: Networking to Promote Professional Status and Educational Change in the Nineteenth Century," History of Education 32, no. 1 (2003): 17-33 Joanne Ailwood, “Mothers, Teachers, Maternalism and Early Childhood Education Care: Some Historical Connections,” Contemporay Issues in Early Childhood 8, no. 2 (2007): 157-65 For similar concepts in Argentina, see Karen Mead, "Beneficent Maternalism: Argentine Motherhood in Comparative Perspective, 1820-1920,” Journal of Women’s History 12, no. 3 (Autumn 2000): 120-45. 
of his curricula as "gifts” and "occupations.” Gifts were material objects to be explored by the senses and connected to applied concepts and ideas. Occupations were activities that allowed for inventiveness and creativity. ${ }^{87}$

Froebel's pedagogical ideas rapidly moved out of Germany to nations around the world, and kindergartens found supporters and proponents in the Americas. In the late nineteenth century, liberal elites in Argentina imagined education as a transformative tool to eradicate colonial legacies and unify the nation. Following the wars of independence, Argentina faced decades of civil unrest between Unitarist, or centralist, and Federalist, or provincial, factions. In the second half of the nineteenth century, Argentina largely overcame its provincial conflicts and began to form a liberal national state with centralized power consolidated in Buenos Aires. Education formed a large tenet of nation-building efforts in late nineteenth century Argentina. ${ }^{88}$

Sarmiento and other education reformers of the liberal Generation of '37, embraced the pedagogical theories of Froebel. Children, considered central throughout the nineteenth century to acculturation processes, were often cited by ruling elites as the bridge between the state and the family. Concerns over the child rearing practices of the growing immigrant population in Buenos Aires produced a response from liberal elites to intervene in family life. The state increasingly took part in constructing new institutions and positivist spatial landscapes for children in the name of Argentina. The spatial model of kindergartens interestingly paralleled other urban projects aimed at opening up green

87. Joe L. Frost, A History of Children's Play and Play Environments: Toward a Contemporary ChildSaving Movement (New York: Routledge, 2010), 26-31.

88. Mark D. Szuchman, "Childhood Education and Politics in Nineteenth-Century Argentina: The Case of Buenos Aires,” Hispanic American Historical Review 70, no. 1 (February 1990): 109-38. 
space and purifying the city in the name of hygiene. Liberal elites imagined these new urban spaces at the crux of civilization and modernity, often criticizing its rural counterparts as backwards. While the rural environment provided plenty of the open air and space boasted by reformers, its uncontrolled state was imagined as dangerous, and breeding grounds for immorality.

For the leading proponent of mass education, President Sarmiento, the dichotomy between rural and urban political forces played out in a larger cultural, and even moral, scale. Sarmiento posited the rural gaucho as the barbarian of the time, as an obstacle to progress and civilization. The city, in contrast, was deemed the beacon of hope where reason and modernity provided a space to educate the new nation. In Sarmiento's controversial Facundo, these themes are played out in his critique of the authoritarian caudillo, Juan Manual de Rosas, through the character of Juan Facundo Quiroga, a gaucho whose upbringing in the rural pampas and lack of education marked his life of barbarism. Sarmiento tells a tale of Quiroga's childhood in San Juan, emphasizing his limited education, “...he could never be induced to take his seat at the family table; in school he was haughty, reserved, unsocial; he never joined the other boys except to head their rebellious proceedings or to beat them.”89 For Sarmiento, Quiroga’s childhood defined his adult life, and he explains that like the childhood stories of Napoleon, Quiroga’s childhood revealed his “true nature,” by which “such natures develop according to the society in which they originate."90

89. Domingo Faustino Sarmiento 1811-1888, Facundo, or Civilization and Barbarism, trans. Mary Mann, introd. by Ilan Stavans (New York, NY: Penguin Books, 1998), 75.

90. Sarmiento 1811-1888, Facundo, 74-75. 
For Sarmiento, education provided his entrance into the modern world. Forced into expatriation to Chile by 1831, he turns to his own autobiography to recall his San Juan childhood in stark contrast to Quiroga's. This, he argued, separated him from the uneducated "barbaros" of the countryside in which he was raised. Sarmiento organized the first training school for teachers in Chile, and soon found himself in the midst of a transnational dialogue about early childhood development, aligning closely with the theoretical nature of the importance of the formative years of childhood. Commissioned by the Chilean government to write a report on the state of popular education in Europe and the United States, Sarmiento traveled throughout the Atlantic world. ${ }^{91}$ Sarmiento studied educational reformers and organizations in Germany, France, England and the United States, cultivating an extensive relationship with the latter. Sarmiento rubbed elbows with notable proponents of education in New England, such as Horace Mann and his wife Mary Peabody.

Sarmiento eventually returned to Argentina, and pushed for common mass education provided by the state. He acted as director of schools in Argentina, a position he created, until he returned to the United States as an ambassador for Argentina in 1861, two years after Horace Mann died. Sarmiento wrote to Mary Peabody Mann, who during the Reconstruction era spent considerable efforts on education, and initiated the sharing of much correspondence in the years to follow. Sarmiento eventually translated her work, the Life of Horace Mann, as a manifesto to Mann's work on education and Mary

91. These reports would become Educación Popular, Santiago 1849. 
Mann reciprocated to translate Sarmiento’s literary work, Facundo, into English in 1868..$^{92}$

Elizabeth Palmer Peabody, Mary’s sister, founded the first kindergarten in the United States and early collaborations between educators of the United States and Argentina often appeared in the name of Froebel's theories on childhood. ${ }^{93}$ One of Argentina's earliest proponents of Froebel’s theories, Juana Paula Manso, was a schoolteacher and novelist born in Buenos Aires. Appointed by Sarmiento as the director of the first public co-educational school in Buenos Aires, Manso acted as the first female to be appointed a position in government in Argentina. She also served as the editor of the educational journal Anales de la educación común. Manso represented an ideal for Sarmiento, who like Froebel, supported the education and training of female teachers. Like Froebel, Sarmiento argued that an infant's education started with the mother in the home, and encouraged the education of female educators for their "nurturing” instinct. ${ }^{94}$ Manso, however, faced fierce criticism for her public activism. She spoke out against a Catholic tradition of relegating women to the domestic sphere, and pushed for new pedagogical practices which included educating girls outside the home. Manso and Sarmiento similarly believed women were crucial to building the nation through

92. Ivan Jaksic, The Hispanic World and American Intellectual Life, 1820-1880 (New York: Palgrave Macmillan, 2007), 166-69.

93. For more Elizabeth Palmer Peabody and her efforts to institutionalize kindergartens the United States, see: Marvin Lazerson, “Urban Reform and Schools: Kindergartens in Massachusetts, 1870-1915,” History of Education Quarterly 11, no. 2 (Summer 1971): 115-42.

94. Julyan G. Peard, “Enchanted Edens and Nation-Making: Juana Manso, Education, Women and TransAmerican Encounters in Nineteenth-Century Argentina,” Journal of Latin American Studies 40, no. 3 (0453-82 2008); Myriam Southwell, “Juana P. Manso (1819-1875),” Perspectivas: Revista Trimestral de Educación Comparada XXXV, no. 1 (Marzo 2005): 117-32. 
education, and focused many efforts on training female educators. Manso challenged the colonial traditions of the Roman Catholic church, the mass eradication of indigenous peoples, and promoted gymnastics and physical education of girls, all of which were labeled immoral in the mid-nineteenth century. ${ }^{95}$

Ultimately, Manso, forced to resign in 1859 from the coeducational school, faced public mockery and even stone throwing by both men and women who opposed her beliefs. She continued to push for secular education and female citizenship until Sarmiento's presidency, when he then appointed her to the National Schools Commission in $1871{ }^{96}$ The challenges Manso faced in 1859 foreshadowed the challenges kindergartens continued to face at the turn of the century. Conflict still existed after the fall of Rosas among porteño elites who held onto a cultural tradition of conservatism. Early childhood education also challenged the utility children served to the family economy and traditional gendered patriarchal roles of the family. Historian, Mark Szuchman explains that, "what remained of the Sarmiento and Manso era were superstructural and organizational reforms; substantive matters of method and epistemological concerns were much slower to sink roots." ${ }^{, 97}$

Like Sarmiento, Manso exchanged letters with Mann, and contributed to the translation of English works into Spanish, such as Horace Mann’s Sobre la Educación,

95. For an extensive analysis of Manso's literary contributions as related to her socio-political beliefs, see chapter 10, “Juana Manso (1819-75): Women in History,” Catherine Davies, Claire Brewster, and Hilary Owen, South American Independence: Gender, Politics, Text (Liverpool: Liverpool University Press, 2006), 241-67.

96. Davies, Brewster, and Owen, South American Independence, 241-44.

97. Szuchman, "Childhood Education and Politics in Nineteenth-Century Argentina: The Case of Buenos Aires,” 130-32. 
which later became a standard text in Argentina's escuelas normales (normal schools), an institution of schools organized by Sarmiento for the training of female teachers. Manso promoted the ideas of Froebel and pushed for kindergarten to be taught by North American teachers at the normal school of the Catholic Sociedad de Beneficencia, the leading charitable organization in Argentina chiefly run by women of the elite oligarchy. The Sociedad, however, did not approve of the incorporation of Protestant ideas nor foreign teachers into their pedagogical practices. ${ }^{98}$ Manso supported the education of women and proposed their participation in the nation was critical to eradicating Argentina’s colonial past and forging a new Republican Argentina. ${ }^{99}$ It wasn’t until 1884, nearly a decade after Manso’s death, that a normal school specifically for kindergarten training was established in Argentina. Even well into the first decades of the twentieth century, proponents of kindergartens continued to face similar challenges as Manso.

Sarmiento played an important role in the early formation of public education in Argentina and through education reforms built a relationship between Argentina and the United States, often comparing himself to Horace Mann. ${ }^{100}$ He embraced new understandings of childhood and came to be regarded as the "father of national

98. Southwell, “Juana P. Manso (1819-1875),” 128-29.

99. For a detailed look at Manso as nation-maker and her conflicts with the Sociedad de Beneficencia, see: Peard, "Enchanted Edens and Nation-Making."

100. Watt Stewart and William Mashall French, "The Influence of Horace Mann on the Educational Ideas of Domingo Faustino Sarmiento,” The Hispanic American Historical Review 20, no. 1 (February 1940): 12; Stewart and Mashall French, “The Influence of Horace Mann,” 12. 
education” in Argentina. ${ }^{101}$ Sarmiento found early education models like the kindergarten attractive, as he passionately regarded mass public education as the key to shaping - and civilizing - the future of Argentina's democratic citizenry. While childhood education was regarded by elites as an important civic component throughout the nation-building process in the nineteenth century, the consolidated efforts of a newly centralized national government in Buenos Aires regarded mass education as crucial to building a stronger network of future citizens. In 1884, Sarmiento’s early education efforts culminated in a common education law, Ley 1420 Educación Común, which provided free, secular and compulsory primary school for ages six to fourteen. The establishment of a National Board of Education regulated public and private schools in the nation's newly established federal capital and brought provincial education under national supervision. Efforts encouraging state sponsored early childhood education led to the articulations of new pedagogical theories, like that of kindergartens, increasingly centering play at the center of young children's development.

North American Sara C. Eccleston established the first training school for kindergarten teachers in 1884, in Paraná. Eccleston, a young widow, graduated from her training of the Froebel method at the Kindergarten Training School in Philadelphia.

After establishing the first kindergarten in connection with the public school system in Minnesota, she lectured for the Kindergarten Training Department of Normal School at Winona State. ${ }^{102}$ Eccleston met Sarmiento through Elizabeth Peabody, Mary Mann’s

101. Dorothy Dee Bailey, "Early History of the Argentine Normal Schools," Peabody Journal of Education 36, no. 1 (July 1958): 19.

102. C. O. Ruggles, "Winona State Normal School, 1860-1910," Written in connection with the preparation for the celebration of the Fiftieth Anniversary of the Opening of the Institution, Historical 
sister. She travelled to Argentina in 1883 as part of the exchange of North American teachers commissioned through Sarmiento's normal school program, started in 1860, to train female Argentine teachers new pedagogical methods. Eccleston eventually was appointed General Inspector and Organizer of Kindergarten and Training Schools for Argentina, founding the first training school for kindergarten in the city of Buenos Aires. ${ }^{103}$

Progressive reformers and educators across the globe adapted Froebel's principles in their own kindergartens to reflect a growing study of childhood development. Many North Americans, like Butterworth, who praised Sarmiento's efforts in the "kindergarten age," appeared fascinated with what he called "progressive Argentina” and drew on the political parallels between Argentina and the United States. ${ }^{104}$ Eccleston aligned with these reformers, describing Argentina as a "progressive republic," in a letter to the International Kindergarten Union in $1916 .{ }^{105}$ Yet, while the United States found a wider acceptance of kindergartens in the early twentieth century, kindergartens in Argentina continued to be met with resistance. Through an analysis of the criticisms and appraisals faced by proponents of kindergartens, we can better understand the parallels between

Sketch and Notes by C.O. Ruggles, Hisotry and Social Sciences, Assisted by Other Members of the Faculty (Winona, MN: Winona State University, 1910), 154.

103. Ruggles, “Winona State Normal School, 1860-1910,” 181-83.

104. Hezekiah Butterworth, South America: A Popular History of the Struggle for Liberty in the Andean Republics and Cuba (New York: Doubleday \& McClure Co., 1898), 174-84.

105. May Murray, ed., "A Message from South America, Reprinted Letter from S.C. Eccleston to Miss Catherine Watkins, President International Kindergarten Union,” The Kindergarten and First Grade 1 (Sept 1916): 462. 
pedagogical transformations and changing definitions of childhood in the broader context of Argentina’s nation-state development.

\section{Kindergarten or Jardín de Infantes}

The term “kindergarten” translates from German to “children’s garden,” and though many early education reformers in Argentina applied the term kindergarten, others preferred, jardín de infantes, the Spanish translation. Rather than frivolous application, the use of such terms held meaning and exposes the sentiment that reformers experimented with and adapted foreign models of education, like kindergartens, to suit the unique local needs of Argentina. It is noteworthy that those most critical of the adoption of North American Froebelian models early on in Argentina preferred to refer to these early childhood institutions as jardínes de infantes. Others, especially more strict disciples of Froebel typically preferred to use the origin name, kindergarten.

Today in Argentina, many regard Eccleston as "La Abuela" of the kindergarten movement, yet her North American, Protestant ideas were not well received by all in Buenos Aires in the first decades of the twentieth century. Eccleston wrote about some of the challenges and criticism kindergartens faced in a 1912 letter sent to the US along with an article titled "Nuestra Kindergarten," published in Revista de Educación. In the letter Eccleston bemoaned the lack of encouraging news to send home, but reflects in the article on the use of the term "Jardínes de Infantes."

Our 'guest' is not a foreigner, as its name seems to imply, but has the genuine claim to citizenship from its twenty-six years of existence in our republic. It has its proper name in our language... but there are so many 'Jardines de Infantes' that 
are mere imitations that the title 'kindergarten' given by its founder, Friedrich Froebel, seems more characteristic and significant. ${ }^{106}$

While Eccleston continued on to attribute the "precarious” existence of kindergartens to a lack of resources, it was fundamentally an ideological shift that she points to as the main cause of their "degeneration." ${ }^{\text {107 }}$ Indeed, most Argentines did not place much value on kindergarten education, and Eccleston faced a mixture of praise and resistance to her strict adherence to the Froebelian method. While kindergartens found widespread acceptance in North America, in both private and public institutions, and amongst various socioeconomic groups, in Argentina, the prevailing interest and subsequent development of kindergartens first appeared as a model to civilize immigrant working class children. The state rapidly expanded a network of public preschool institutions, and by 1909 there were 44 established in Buenos Aires. ${ }^{108}$ Yet, Eccleston and others devoted to the Froebel methodology described these as mere "imitations" of kindergarten.

In Eccleston's efforts to establish a kindergarten movement in Argentina, she translated English literature into Spanish for use at the training schools. Most notably, in 1896, she translated Bertha von Merholtz-Bülow’s The Child and Child-Nature, which aimed to provide a greater understanding of Froebel's theories and philosophies to be

106. S. C. Eccleston, “Nuestro Kindergarten,” Kindergarten Review 23 (October 1912): 121-22.

107. S. C. Eccleston, "Nuestro Kindergarten,” 121. One could also read further that Eccleston was justifying her own allegiance to Argentina, as she often did, signifying "our republic," referencing Argentina and not her homeland of the United States.

108. Municipalidad de la Ciudad de Buenos Aires, Censo general de población, edificación, comercio e industrias de la Ciudad de Buenos Aires 1909, (Buenos Aires, Compañía Sudamericana de Billetes de Banco, 1910), 339. More research is needed to determine how many of these followed the Froebel method. 
applied in kindergarten training. Perhaps in an effort to appear more Argentine, the edition was printed in blue and white, the colors of the Argentine national flag. ${ }^{109}$

Training guides were often translated and adapted from North American texts. Sometimes this caused issues in the classrooms, when the needs and knowledge of local teachers were not considered in the manuals. For example, one Argentine kindergarten teacher expressed the difficulty she faced in the classroom when her lesson called for “playing bunnies,” and she was not familiar with the North American pastime of children creating shadow puppets of bunnies with their hands. ${ }^{110}$ The teacher improvised by having the children act out the behaviors of rabbits, but pointed to her frustration and the need to better adapt teaching manuals to the local needs and customs of Argentine children. The "foreign” nature of the kindergarten movement proved as a point of contention throughout its early history.

In 1910, at the First American Child’s Congress in Buenos Aires and centennial celebration of Argentina’s independence, a poster titled, “El Kindergarten,” claimed that half a million children in the United States went to kindergarten between ages four and six for training. Emphasizing the utility of kindergartens to train future citizens, the poster depicts girls and boys running and playing with blocks and crafts. ${ }^{111}$ Later, in its reprinting in The Kindergarten and First Grade, the editor expressed her hope that "the people of South America will be impressed by the record of the US and work for the

109. “Bibliografia: El Niño y Su Naturaleza,” El Monitor de la Educación Común, no. 279 (Octubre 31 1896): 909.

110. Zuluaga, “Los Conejitos,” 298.

111. Picture of Buenos Aires exhibit, "El Kindergarten,” reprinted in: May Murray, ed., "Kindergarten Exhibit, South America,” The Kindergarten and First Grade 1 (September 1916): 321. 
general adoption of this method of education for their own little children."112 There was indeed a missionary like sentiment projected from United States reformers to bring "every boy and girl... [the] advantage of such happy and valuable education" in Argentina. ${ }^{113}$ In 1918, Hardynia K. Norville, writing from Buenos Aires, described the temperance movement as growing in the city due largely to evangelical Christian workers. She pushed for a system of free kindergartens, calling on the evangelical community to donate money for an English-speaking training school in Buenos Aires. Her pleas, in the midst of several stories of drunken parents, decried that, "one baby under two years of age dies every twelve minutes in this city" ${ }^{, 14}$ Comments like these from the United States aligned with the positivist discourse of the liberal elite, who presented kindergartens as a way to reform and control the customs of the popular classes.

The construction of kindergartens in many ways paralleled positivist urban welfare reforms in Argentina. Establishing hygienic practices amongst families and developing new "healthful" spaces played a large part in positivist transformations to the urban landscape at the turn of the century. At the same time, these new spaces were promoted to create a more ordered, civilized society. ${ }^{115}$ Like city planners, early childhood education reformers attempted to construct an ideal environment for the

\footnotetext{
112. Murray, "Kindergarten Exhibit, South America,” 322.

113. Murray, “Kindergarten Exhibit, South America,” 322.

114. Hardynia K. Norville, “Temperance Sentiment Growing in the Argentine Republic,” The Union Signal XLIV, no. 33 (12 September 1918): 33.
}

115. A detailed analyses of how these themes played out within the city of Buenos Aires are explored in more detail in the next chapter, "The Boundaries of Play." 
development of an ideal childhood. The development of parks and plazas provided spaces of socialization for adults between the home and work, a tenet of late-nineteenth century urban planning. ${ }^{116}$ Particularly in areas where overcrowded domestic space did not permit "healthy" socialization in the home, calls for more spaces of public socialization were deemed critical for the health and well being of cities.

In 1898, the International Association of Kindergarten was formed in Argentina, following the creation of the Unión Fröebeliana Argentina. These organizations praised Froebel as the "master" or "great" educator and served largely as disciples to his teachings. Eccleston, in the inauguration address to the association, discussed the importance of an international union to combat "enemies" of the kindergarten movement, referring largely to those that failed to follow the Froebel method. While the kindergarten model served the state's interest to oversee the popular classes, Froebel's pedagogy of play and emphasis on catering to children’s individual development clashed with the positivist normalism institution in which it was formed. ${ }^{117}$

\section{Between Home and School}

In an 1888 article in El Monitor de la Educación Común, kindergarten is described, not as a school, but as preparation for it. The author emphasizes the role of the teacher's affection and guidance, "The teacher... has to be affectionate to her flock like a loving parent." ${ }^{, 18}$ The notion that kindergartens were a special space, in-between the

\footnotetext{
116. Diego Armus, The Ailing City: Health, Tuberculosis, and Culture in Buenos Aires, 1870-1950 (Durham and London: Duke University Press, 2011).

117. Sandra Carli, “The new school movement in Argentina," Paedagogica historica 42, no. 03 (2006): 385.

118. “El Kindergarten : Jardines de la Infancia,” Monitor de la Educación Común 9, no. 135 (1888): 682.
} 
home and school, provided a critical state discourse to encourage engagement and intervention in early childhood. Elites imagined kindergartens as a necessary supplement to the working class home, a space to remedy the perceived failures of those families. State actors increasingly cited parental negligence to justify the need for state intervention in children's lives through health and education reforms. While the kindergarten movement in Argentina elevated the status of some women in public life, through the broader training of female teachers, the justification for educating girls was to produce a future ideal motherhood and eventually eliminate the need for kindergartens all together. ${ }^{119}$ While Froebel idealized the kindergarten movement to extend to all socioeconomic classes, the challenges of entering the traditional domestic space of childhood, especially amongst the elite, made difficult the widespread development of kindergartens in Argentina.

For reformers to justify removing children as young as three years old from their traditionally bound familial practices, kindergartens were regarded as a healthful space in-between the home and school. In the same article that equated the behaviors of kindergarten teachers and parents, the author strikes a cord with nation-building discourse of the time, quoting Froebel, "I see in every child the material necessary to make a perfect man.,120 Froebel's methods discouraged formal textbook instruction, and instead emphasized interactions with the material natural world, a significant trope of modern

119. Guy examines the participation of women in the rise of what she refers to as the "welfare state." A discourse on child welfare and family reform was paramount to female philanthropic groups and feminist groups. For a detailed examination, see Donna J. Guy, Women Build the Welfare State: Performing Charity and Creating Rights in Argentina, 1880-1955 (Durham and London: Duke University Press, 2009).

120. “El Kindergarten,” 686. 
urban planning. The social environment of kindergartens, as well as its spatial prescriptions, focused childhood interactions on introducing materials to children for them to explore and discover meaning using all of their senses.

Froebel also regarded the children themselves as material, to be molded and shaped through the guidance of the kindergarten teachers. The construction of kindergartens, thus, necessitated much more consideration to space than a typical classroom, as the environment was incorporated into the pedagogy. Kindergartens often included flower and vegetable gardens for children to experience the natural cycles of plant life, to work with their hands, to plant them, to nourish them with soil, water and light, and to nurture them with love so that they grow (See Figure 2.1). A common theme in the discourse on kindergartens was to consider them as a symbolic garden of children, rather than just a garden for children. Much like a plant, the children needed nourishment, adequate light and clean air. If allowed to grow wild, without guidance, children became like weeds, a nuisance to the garden. ${ }^{121}$ Similarly to state discourse on the urban environment, society needed healthful green spaces of leisure and guidance to establish an ordered society. For late nineteenth century urbanists and hygienists, Froebel's ideal of childhood space did not exist in the domestic sphere of the majority of urban sectors. The largely immigrant working class of Buenos Aires lived in crowded one-room households or tenement style housing. ${ }^{122}$ The late-nineteenth century witnessed a plethora of health campaigns to rid cities of both unsanitary conditions and unwanted

121. “El Kindergarten,” 685-86.

122. David Rock, Argentina 1516-1987: From Spanish Colonization to Alfonsin (Berkeley Los Angeles: University of California Press, 1987), 175-76. 
social behaviors, often through providing healthful spaces outside of the domestic sphere. ${ }^{123}$ For state authorities, kindergartens provided an attractive environment to develop an ideal Argentine childhood, outside of the home, while also answering many concerns over providing healthful spaces for children.

Figure 2.1: Children at recess in kindergarten, Buenos Aires, $1899^{124}$

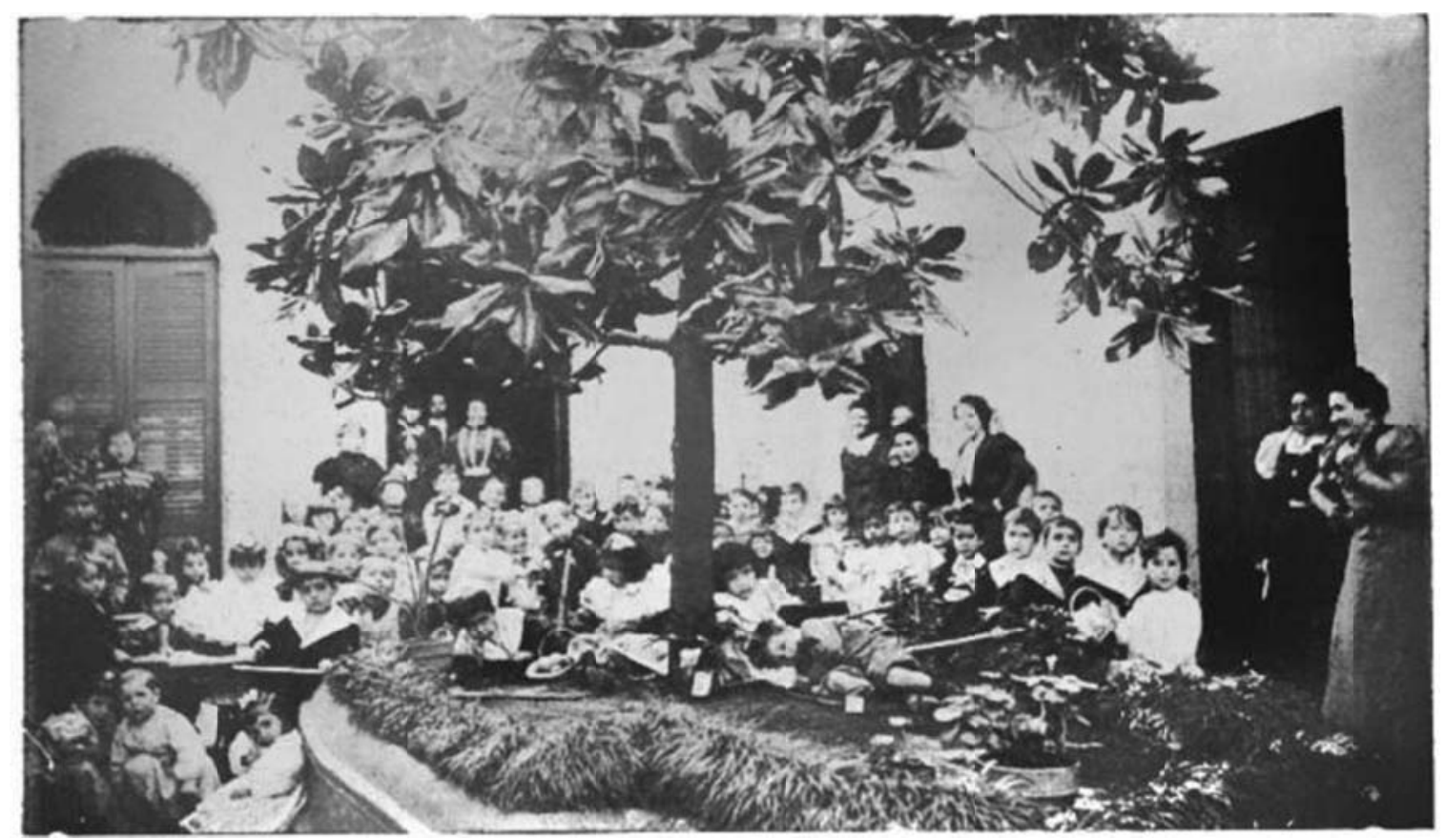

The design and organization of space within the kindergartens was crucial for the implementation of the new pedagogy. Kindergartens generally consisted of at least two distinct spaces. One area, typically an outdoor patio, provided an open space for play and physical exercise. Ideally this space would include a garden for the children to tend and

123. For more on urbanism in the Progessive era, see Michael H. Frisch, "Urban Theorists, Urban Reform, and American Political Culture in the Progressive Period,” Political Science Quarterly 97, no. 2 (Summer 1982): 295-315.

124. ”Niños en el recreo,” Foto de Caras y Caretas, “Los Jardines de Infantes,” Caras y Caretas II, no. 64 (23 de Diciembre 1899). 
rest outside in. The other space more closely resembled a traditional classroom. Emphasis was placed on the organization of the room. Desks and chairs, sized for a small child, were organized in straight lines, crossing at right angles to form a square. The instructor often used the spatial organization of the room to teach children how to count, methods of organization and measurement of distances. ${ }^{125}$

The use of these two distinct spaces, in many ways, resembled contemporary spatial reorganization of the city of Buenos Aires. Vast gardens, plazas and other green spaces transformed the landscape of the city in efforts to increase the population's use of clean air and sunlight, deemed crucial for the prevention of disease. Similarly, the kindergarten model in Buenos Aires emphasized allowing fresh air and sunlight to pass into the kindergarten. Large windows and the movement between two spaces allowed for each space to be ventilated while the other was in use. The reinvigoration and connection to nature through the use of gardens similarly linked progressive ideas that human's development rested on its access to natural hygienic space.

For Froebel, kindergartens provided what many families could not provide, healthy socialization with peers, structured early education and deep spiritual connections with nature and God. They acted as a space in between the home and school, and in many ways were regarded as temporary spaces. Froebel hoped that the perpetuation of kindergartens would teach young girls to be more "spiritual" mothers, so that eventually, they could teach their own kindergartens at home. He often utilized the symbolic garden to demonstrate that the child's first education ideally started home:

125. "El Kindergarten,” 683; “The International Kindergarten Union: Notes on the Colorado Tour,” Kindergarten Magazine VIII, no. 1 (September 1895): 29-38. 
Parents, let your home a children's garden be, Where with watchful love the young plant's growth you see:

A shelter let it be to them from all

The dangers which their bodies may befall;

And still more a soil in which will grow, The inward forces that from God do flow;

Which with a father's love He unto men has given, That by their use they may upraise themselves to heaven. ${ }^{126}$

Froebel regarded the mother as the first educator, and was critical of children

being raised by nurses and servants. As Marenholts-Bülow describes in The Child and Child-Nature, "the children of wealthy parents, who are surrounded by numbers of attendants... frequently grow up with weak unstable affections.”127 Similarly, Froebel was critical of children growing up in orphanages, for they "will generally be found to have a melancholy, listless expression of countenance.”128 Kindergartens, thus, provided a foundation for the future "spiritual mother," which expressed this ideal of the mother as the first and most important educator in a child's life. ${ }^{129}$ Emphasis was placed on the permanence and irreplaceability of the home, while the nature of Froebel's ideal kindergarten was inherently temporary.

This sentiment clearly resonated in Buenos Aires, though there was little criticism of the elite family. Emphasis instead fell on impoverished families, for which the state increasingly regulated as unable to care for their children. In 1873, the Department of Schools asked for kindergartens to be added to each of the primary schools, stressing the

126. In Froebel's book for mothers, quote taken from Bertha Maria Marenholtz-Bülow, The Child and Child-Nature (Syracuse, NY: C.W. Bardeen, 1895), 104.

127. Marenholtz-Bülow, The Child and Child-Nature, 128.

128. Marenholtz-Bülow, The Child and Child-Nature, 128.

129. Marenholtz-Bülow, The Child and Child-Nature, 99-100. 
importance of the Froebelian method and training to socialization and the future citizenship of the children. The kindergarten would act to "replace maternal care," only when the mother was unable to provide it. In the request, the Department reflects on the state of mothers, unable to care for their children:

Not all parents can stay with their children during the day, forcing many to leave them locked up at home, with all the dangers of isolation, or left with untrustworthy people, or to allow them to wander the plazas, streets and fields, or to the peril of their life, they are given another house, another family... ${ }^{130}$

The request also points to European models of kindergartens, such as public education in Austria as an example where compulsory kindergarten education required children aged four to six to attend. The many benefits of these kindergartens in Europe, they exclaimed included physical health, military prowess and integrity. ${ }^{131}$ However the efforts by the state to establish and enforce compulsory education, let alone compulsory kindergartens, were difficult to realize.

The state, never the less, attempted to address the perceived social ills of the time, within the context of kindergartens, through the reeducation of working class mothers. Critical of mothers who give in to their impulses, Marenholtz-Bulow describes Froebel's method as the "true science for mothers," and that through the kindergarten "the family will be rendered capable of fulfilling its educational task."132 Here again, the temporary nature of kindergartens is emphasized, for once the mother, or future mother, learned the

130. Antonio Zinny, “Jardines de Infantes, Kindergarten o Escuelas de Parvulos,” in Memoria del Departamento de Escuelas al Gobierno de la Provincia de Buenos Aires Corresondiente Al Año 1873 (Buenos Aires, 1874), 16.

131. Zinny, “Jardines de Infantes, Kindergarten o Escuelas de Parvulos,” 17-18.

132. Marenholtz-Bülow, The Child and Child-Nature, 11. 
method, she could apply it in her home, and of course, teach her daughters to perpetuate the Frobelian ideal. Thus, alongside changing definitions of childhood, concepts of motherhood too were reimagined.

Proponents of kindergartens in Argentina criticized mothers' lack of hygienic knowledge. For example, one kindergarten teacher blamed a mother for abuse when her child got sick with typhus. The teacher argued the mother neglected the child's health by depriving him of physical movement. ${ }^{133}$ Kindergarten literature presented the theme of the reformed mother often. Marenholtz-Bulow argued that, "the Kindergarten begins on the mother's lap," and encouraged mothers to participate in the kindergartens and learn from them so that, "all mothers one day, we hope, be equal to this task."134 The establishment of the kindergarten normal school, similarly to other positivist "normalism" methods of the time, sought not only the regulation of training methods in schools, but to also permeate private life, particularly in regards to hygiene and household management practices within the home. ${ }^{135}$

Sarah Eccleston often described kindergartens as if they were "extensions of the dwelling," not to replace the home, but to support it. Le Corbusier, many years later, used this term to describe how parks and gardens functioned for kindergartens, schools and recreational facilities. By mid-twentieth century, these spaces provided, for Le

133. Custodia Zuluaga, "Los Conejitos:

Trabajo Leído en la A. I. de Kindergarten por la Señorita Custodia Zuluaga,” La Educación 13, no. 292294 (1898): 297.

134. Marenholtz-Bülow, The Child and Child-Nature, 99.

135. Carli, "The new school movement in Argentina,” 385. 
Corbusier, rational solutions to urban problems. ${ }^{136}$ Eccleston translated an article of Mary Mann for the Monitor de la Educación in 1899, where she states that kindergartens are the "greatest discovery of modern times," because through them, all of society could be transformed. ${ }^{137}$ One of Eccleston’s Kindergarten graduates, Justa Gomez, later reiterated the importance of early intervention in childhood education. Gomez states there is not enough study of the "nature of children," stating that mothers imagine there will be plenty of time to correct "bad habits," but Gomez argues this is much more difficult later in life. ${ }^{138}$ Like many disciples of Froebel, emphasis was placed on intervention into domestic life at the earliest phases of childhood.

Hygienist, José Soloma, at the Fourth International School of Hygiene, echoed fears over the ways working class parents reared their children. He discussed how young children, between four and six years old, reproduced in their play and past-times, the actions of the adults they lived with. This, Soloma argued, could be inspiring or tragic, depending on the adult's influence. Dr. Ernesto Nelson, a pedagogue who focused on increasing children’s play and exercise in order to reduce delinquency in Buenos Aires, argued that, "the child is not sufficiently considered in the family or school," and similarly to Eccleston and Gomez, Nelson called for more studies of the child, "to

136. Le Corbusier, Looking at City Planning, 1st, Eleanor Levieux (New York: Grossman Publishers, 1971), 154-55.

137. Mary Mann and Sara Chamberlain de Eccleston, "El Kindergarten Ó La Nueva Educación, Por la Esposa de Horacio Mann,” Monitor de la Educación Común (1899).

138. Justa Gomez, “Field Notes,” Kindergarten Magazine V, no. 2 (October 1892): 236-37 Paper was translated by Eccleston and published in the "Field Notes" section of the magazine. 
consider what he wants," rather than reserving those privileges for adults. ${ }^{139}$ Nelson’s focus on the child's individuality and the necessity to understand the child in order to raise good citizens can be viewed in the larger context of the positivist model of education in late nineteenth century Argentina. The state emphasized the hygienic and education failures within the home to reiterate the need for a space in-between to create an ideal -civilized- childhood environment. However, state actors in the first decades of the twentieth century emphasized political aspirations to produce ordered citizens over new concepts of children that emphasized their individualism. Froebel's ideas about the "nature” of children's wants and needs indeed challenged the didactic training of kindergarten teachers under the positivist normal school model.

Still, criticisms of motherhood served to encourage the education of girls, albeit largely under the umbrella of training for future motherhood. A professor of kindergarten wrote about meeting mothers who were anxious about sending their daughters to kindergarten, believing that school did not satisfactorily prepare girls for life. ${ }^{140}$ Froebel believed that educating girls was crucial to conceiving an ideal society and ideal family life. Women were crucial to both, as mothers and educators. He argued their natural ability to nurture enabled them best to care for children, but not much else. ${ }^{141}$ While the kindergarten professor tells mothers that kindergarten provided the best training for their

139. Missionary Education Movement, Christian Work in Latin America Survey and Occupation, Message and Method Education Being the Reports of the Commissions, I, Ii and III Presented to the Congress on Christian Work in Latin America, Panama, February, 1917. (London: Forgotten Books, 2013, reprint), 410.

140. Sara Chamberlain de Eccleston, traductor, “Nuestras Hijas y el Kindergarten,” La Educación 13, no. 288 (1898): 210.

141. Allen, "Spiritual Motherhood,” 325. 
daughters, she reiterates Froebel's sentiment, that this education will prepare them to be “a wife, mother, teacher, governess or a director of kindergarten."142 While the pedagogy of play was important for girls to learn about human movement and development, it was largely in preparation for her future role as a female nurturer (See Figure 2.2).

Figure 2.2: Kindergarten girls playing with dolls, $1899^{143}$

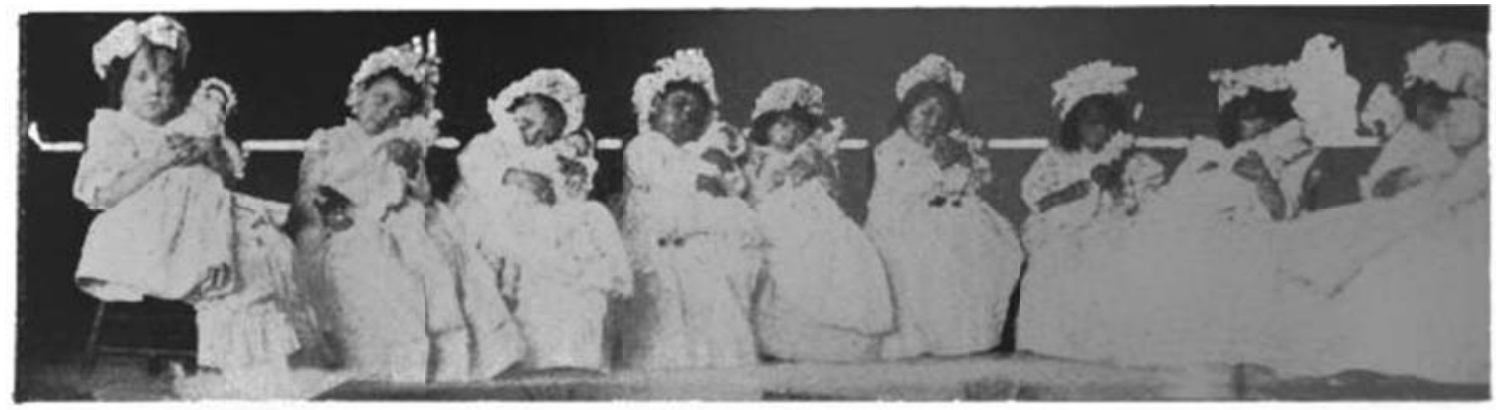

In an 1888 article published in the Monitor de la Educación Común, the daily routines of kindergartens are described, as taught in Buenos Aires. Preparatory in nature for future instruction, emphasis is placed on self-discovery and impulse control. A typical day in the kindergarten in Buenos Aires consisted of three hours, divided into half hour sessions "to permit for alternations between work and fun, and to prevent the little ones from getting confused. ${ }^{144}$ These half hour sessions attempted to balance the impulsive nature of childhood with the simultaneous desire of developing ordered future working adults. To do this, the sessions theoretically allowed for guided self-discovery, physical exercise and organized play, dexterity drills that encouraged both creativity and

142. Sara Chamberlain de Eccleston, “Nuestras Hijas y el Kindergarten,” 210.

143. “Grupo de niñas en el juego de ‘La muñeca’,” Foto de Caras y Caretas, “Los Jardines de Infantes.” 144. “El Kindergarten,” 683. 
craftsmanship and finally child-directed discussion groups. This simultaneous desire to allow children to be spontaneous and creative, while also providing structure and order appeared an obstacle in training teachers.

The daily description continued to emphasize this balance between Froebelian self-discovery and notions of order in Argentine educational tradition. Though the six half-hour sessions varied from day to day, they typically followed a similar model. The first session typically began with the children marching to rhythmic music, followed by the instructor telling a short story that preferably included moral undertones. The instructor encouraged the children to discuss subjects that interested them, however emphasis was placed on speaking in turn as the instructor guided them. Sometimes they sang songs, but again the end goal was to encourage good moral behavior and civic character. Children marched between sessions, ideally in a separate space. The second session was devoted to the study of Froebel's gifts, and the third to physical exercise. Lunch was followed by a session of craftwork and the final session typically involved a group game accompanied by music and singing, again incorporating a moral lesson into the game or song. ${ }^{145}$

Sra. Elena Segot, in an 1883 pedagogical conference in Buenos Aires, outlined that the major flaw she saw in Froebel's method was a lack of discipline. ${ }^{146}$ While Froebel's kindergarten required the guidance of a teacher, the focus laid on the nourishment and development of the natural child, centered on the pace by which the

145. "El Kindergarten,” 682-84.

146. Sra. Elena Segot, “Jardines de Infantes,” Sesión del 20 de Mayo in Conferencias Pedagógicas : Sección Doctrinal, Monitor de la Educación Común (1883), 125-33. 
child acquired experience and learned on their own. A theory of punishment did not fit into Froebel's theories, since it was up to the teachers to guide children, in this early stage of development, towards good human character. For Froebel, children were innately good, and any misdirection originated in the child's parents, teachers or social environment. ${ }^{147}$ Criticism of kindergartens equated this child-centered methodology to North American selfish individualism. In the same conference proceedings, Segot cited the example of children freely cutting paper as a drawback of Froebel's method, arguing that it fed the destructive tendencies of children and lacked sympathy for the director of the kindergarten. Segot and others in the late nineteenth century rejected a model that lacked discipline and control; one they believed didn’t promote order and civility. ${ }^{148}$

The entrance of Froebelian kindergarten ideas through the positivist normal school movement in Argentina found little acceptance early on. While preschools flourished, especially for girls, few Argentines found educational value in the Froebel method. Traditional families thought it was absurd to allow children to guide themselves through the learning process at such a young age and viewed play as entertainment rather than education. ${ }^{149}$ Others viewed these methods of state instruction as too invasive into family life. The popular classes also rejected positivist state education as a "malevolent,

147. Therese G. Montefiore, The Ethical Teaching of Froebel as Gathered from His Works, Two Essays (London: Kegan Paul, Trench \& Co., 1890), 82-87.

148. Segot, “Jardines de Infantes,” 125-26.

149. Marifran Carlson, ; Feminismo!: The Woman's Movement in Argentina, (Chicago Review Press, 2005), 78. 
disciplinary tool." ${ }^{150}$ While some parents embraced preschools, most did not connect with the Froebel theories on play and self-discovery.

Despite these early difficulties, disciples of Froebel, like Eccleston, formed a critical discourse for later proponents of the "escuela nueva" in the 1920s and 1930s. Historian Sandra Carli describes these "new school” ideas, which began to spread after the first national elections in 1916 as critical of the practices of positivist normalism. This movement included a rescuing of "educational and philosophical history references that had been neglected or ignored by the so-called traditional pedagogy.” 151 Consequently a renewed Nationalist movement identifying with deeply rooted Catholic tradition in the 1930s continued to challenge the Froebel method as a distinctly foreign model too focused on individualism. Historian David Rock notes, in his work on the Nationalist movement in Argentina, that the movement's “earliest incarnations occurred in the 1880s during the conflicts of education.",152

The difficulties faced by proponents of kindergartens and other pedagogies of play provide insight into the many tensions between families and a growing state apparatus in Buenos Aires, but also speaks to the wider difficulties Latin American central governments faced in attempting to adopt what was viewed as foreign models of governance. Often conflicting with the traditions of traditional family life, proponents of early education models in Buenos Aires, like Kindergartens, worked closely with North

150. Juan Suriano, Paradoxes of Utopia: Anarchist Culture and Politics in Buenos Aires, 1890-1910, (AK Press, 2010), 147.

151. Carli, "The new school movement in Argentina,” 397.

152. Rock, Authoritarian Argentina, xx. 
American leaders to build similar ideologies of childhood and progressive structures of state-led education. The reluctance to accept these models, rather than underlining shortcomings or a lack of progress, speaks to the continued struggle to create a common sense of Argentinidad in a complex landscape well into the twentieth century 


\section{CHAPTER III}

\section{THE BOUNDARIES OF PLAY}

This chapter examines constructed urban spaces of childhood in the first decades of the twentieth century in Buenos Aires. It explores how the socio-spatial engineering of public parks and concepts of play shaped the discourse of an urban "modern” childhood within the city. State and municipal authorities implemented physical education programs and open-air schools within parks to "normalize” children deemed physically or mentally "weak,” which largely targeted children of working class families. State and municipal authorities deemed these children as a threat to elite conceptions of modern society. I examine two examples in the southern barrios of Buenos Aires, Parque Patricios and Parque Lezama, where child-saving programs were put into place in the name of health and hygiene. Both sanitizing and exclusionary practices served to create these spaces within an area deemed unsafe and morally corrupt. Through the analysis of "spatial-discourses" of children who did not meet the expectations of the elite, a greater understanding of the production of modern childhood and its other is revealed. ${ }^{153}$

\section{Unequal Landscapes}

Early twentieth century travelers to Buenos Aires marveled at the new Plaza de Mayo and the vast green parks in Palermo. These major transformations to the urban fabric of Buenos Aires marked its move toward a "modern metropolis,” with developed infrastructure on an organized grid system, improved sanitation efforts and the development of widened boulevards, green parks and plazas. European landscape

153. Sarah Holloway and Gill Valentine, eds., Children's Geographies: Playing, Living, Learning, Critical Geographies (London ; New York, N.Y.: Routledge, 2000). 
architects largely followed a Huassmannic Parisian model in the newly formed national capital. The imposed grid system, widened streets and expanded green spaces served to create a new urban identity for Buenos Aires, while they also promoted modern sanitation efforts and improved the flow and control of people within the city. ${ }^{154}$

Stark contrasts however existed just south of the city’s center. Less than a mile south of the Plaza de Mayo, on the edge of a region with a stigmatized history, could be found an area of the city that continues to hold sordid stereotypes today. A highly contested space, today the neighborhood of la Boca at once boasts its Italian immigrant heritage while embracing a phobia of poverty and menacing danger. This narrative of poverty and decay cast a shadow on my own research experiences. While conducting field research, a friend and I wandered off on-foot approximately two blocks away from Caminito, a nearly 100 meter long tourist spot in la Boca, known for its brightly painted buildings and tango history. Police noticed us, two tourist(as), snapping photos "out of place.” They promptly escorted us into the backseats of their vehicle and drove us back to Caminito. The officers warned that it was too dangerous for tourists to be wandering in this neighborhood, hailed down a cab and sent us on our way. I encountered this menacing sentiment often. Southern Buenos Aires was bohemian-chic, but also a space of danger and mystery. Stories of visitors having their belongings snatched, or unsuspecting foreigners robbed by unregistered taxi drivers, made it clear that this area of southern Buenos Aires was imagined, particularly for expatriates, as a dangerous space. Anthropologist Emanuela Guano describes the development of this spatial experience,

154. Ramón Gutiérrez, "Buenos Aires, A Great European City," in Planning Latin America's Capital Cities 1850-1950, ed. Arturo Almandoz (London; New York: Routledge, 2002), 45-74. 
how a "boquense middle-class spatialized its narrative of the cultured respectable self and its dangerous other."155 Guano points to a narrative of differentiation that developed during the 1990s economic decline, which subsequently blurred the lines between the middle class and the poor. Guano experienced similar warnings of the dangers of la Boca and notes "clear cut spatial boundaries" organized between safe places "sanitized” by the middle-class, and dangerous places contaminated by a mestizo tenement population. ${ }^{156}$ These spaces were not only clearly established in urban discourse, but also mapped out and mass-produced in guides and tours.

This late twentieth century spatial discourse resonates with urban discourse at the turn of the nineteenth century, where socio-economic lines began to blur and both sanitizing and boundary-making projects developed to define the early twentieth century Buenos Aires landscape. In the 1870s, the southern districts of Barracas and la Boca, neighboring Plaza Constitución, lay on the outskirts of the city. (See Figure 3.1) Hospitals, asylums and a cemetery marked the landscape near the Plaza Constitución, where lines of carts could be found at the entrance of an open market. A large slaughterhouse laid just west of the Plaza and the low-lying la Boca to the east. ${ }^{157}$ An outbreak of yellow fever in 1871 reinforced the already stigmatized region, which had been hit by a cholera epidemic the decade before. Without the knowledge that mosquitos carried yellow fever, porteños blamed overall unsanitary living conditions, such as

155. Emanuela Guano, "A Stroll Through la Boca: The Politics and Poetics of Spatial Experience in a Buenos Aires Neighborhood,” Space and Culture 6, no. 4 (November 2003): 358.

156. Guano, “A Stroll Through la Boca,” 359.

157. James R. Scobie, Buenos Aires: Plaza to Suburb, 1870-1910 (New York: Oxford University Press, 1974), 56-57. 
garbage in the street and overcrowded tenement housing, for the epidemic that claimed the lives of nearly $14,000 .{ }^{158}$ Thousands of people also fled the city until the death toll started to decline in the colder months. Historian James Scobie describes in his monograph on the history of the city how the epidemic provided an impetus for wealthier families to distance themselves from the southern regions of the Plaza de Mayo, moving and expanding northward to Barrio Norte. The drawbacks and stigma of the southern region found its promise, however, for workers looking for affordable land to own and was settled largely by Italian immigrants. ${ }^{159}$

Figure 3.1: Map of Buenos Aires, $1870^{160}$

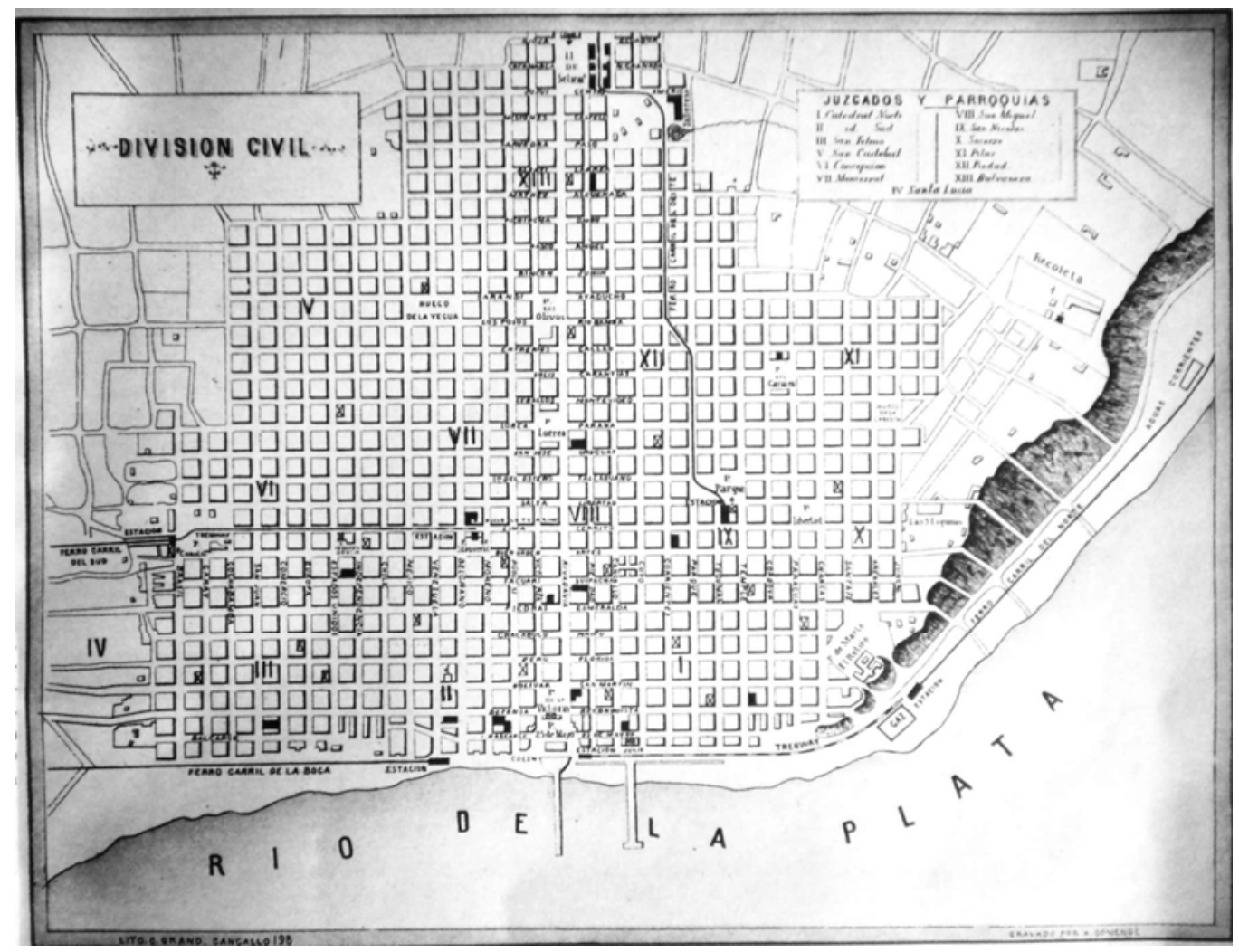

158. Scobie, Buenos Aires, 123.

159. Scobie, Buenos Aires, 124-27.

160. Buenos Aires Maps, "Plano de Buenos Aires 1870.” 
Elites grew increasingly anxious of the largely European masses, especially the rise of skilled immigrant workers and their participation in labor movements. Historian Jean Delaney argues that, "these class anxieties intersected with, and were reinforced by, growing concerns about the moral and psychic costs of modernity"161 While progressive nineteenth-century Argentines encouraged European immigration and material culture in order to modernize - and civilize - the nation, Delaney explains a shift occurred in the twentieth century. During a period of economic prosperity, the immigrant turned into a degenerative symbol of modernity that too easily crossed class lines. Ease of access to transportation networks also increased the visibility of the working class, and many elites preferred to keep them out of their social spaces. Similarly to the late twentieth century, elite fears of the upward mobility of immigrants developed into a spatial narrative of the respectable elite in the northern barrios of Buenos Aires and the dangerous "other" in the southern region. This is a narrative whose echoes can still be heard today.

An environmentally deterministic understanding of poverty, disease and immorality fueled elite fears. Increasingly, members of the privileged class viewed the rapidly growing urban environment as filled with pathogens in need of being contained. The yellow fever epidemic, in addition to shifting the socio-spatial boundaries of the city, also fueled city efforts to conduct major public works projects aimed at improving the health and hygiene of the city. Similar to the professionals in other nineteenth century metropolises, planners in Buenos Aires noted the important role that parks and green spaces played to the maintenance of the health and hygiene of the city. In 1887, the

161. Jeane Delaney, "Making Sense of Modernity: Changing Attitudes Toward the Immigrant and the Gaucho in Turn-of-the-Century Argentina," Comparative Studies in Society and History 38, no. 03 (July 1996): 437. 
city's census paraphrased Jean Baptiste Fonssagrives, a notable doctor who promoted the sanitizing effect of open air and foliage, that parks, gardens and public squares played a vital role in the city, "not only favorable to the welfare and recreation of the people, but also essential for good urban hygiene.”162

The parks of Palermo provided clean, hygienic spaces within the city, but increasingly at the end of the nineteenth century, the elite sought to restrict access to the poor of the largest green spaces in Palermo. Municipal efforts thus began to create green spaces in the southern barrios, often referred to in the era as a "Palermo de los Pobres." Two new parks explored in this chapter, Parque de los Patricios and Parque Lezama, were imagined by planners to provide a Palermo-like space for the poor. When municipal authorities acquired the property that would become Parque Lezama in 1887, the city council exclaimed that the projected park would be “...to the south what the Parque 3 de Febrero is to the north.”163 The largest park in the region, Parque de los Patricios, broke ground in 1902 on site of the once largest slaughterhouse in the city. Though politicians called for more egalitarian hygienic green spaces for the people of the city, by 1909, the northern elite still enjoyed thirteen times more park space than the southern region, with over six million square meters of lush green landscapes. Alone, Parque 3 de Febrero, the largest park in Palermo, encompassed over 5 million square

162. Dr. Don Antonio F. Crespo, Intendente), Latzina, Francisco <compiler, Censo General de Población, Edificacion, Comercio É Industrias de la Ciudad de Buenos Aires Capital Federal de la República Argentina, Levantado en los Días 17 de Agosto, 15 y 30 de Setiembre de 1887, Tomo Primero (Buenos Aires: Campañía Sud-Americana de Billetes de Banco, 1889), 109-10.

163. Crespo, Censo General de la Ciudad de Buenos Aires 1887, 116. 
meters, while the newly constructed Parque de los Patricios, the largest park in the southern barrios consisted of just over 200 thousand. ${ }^{164}$

While turn of the century travelers and guides praised the landscapes of Palermo, the barrios south of Constitución were usually only mentioned by teachers and medical professionals. Though the new parks were touted as important hygienic landscapes for the poor, they also served to exclude the poor from elite spaces. Elite fears of the spread of disease, immorality and poverty led to various boundary-making practices to exclude the poor from their social spaces. Urban centers throughout the world pushed hospitals and asylums out of sight in the late nineteenth century. Only two years after the yellow fever epidemic, the city’s main foundling home, Casa de Niños Expósitos, was moved from its location near the Plaza de Mayo, to a newly constructed building just two blocks southeast of the Plaza Constitución. The new building provided improved sanitary conditions, large windows to allow fresh air and light, and more grounds for outdoor activities (See Figure 3.2). Yet, it also signaled an increasing desire to remove the unhealthy and unsightly from the stage of modern society. Historian Jonathan D. Ablard, in his work on psychiatry and its patients in Buenos Aires, notes that though asylums were typically built outside of cities in the nineteenth century, due to limited transportation in Buenos Aires, they were built within the city on the southern outskirts in Barracas. $^{165}$

164. Don Manuel J. Güraldes, intendente, Alberto B. Martinez, dir., Censo General de Población, Comercio É Industrias de la Ciudad de Buenos Aires Capital Federal de la República Argentina, Levantado en los Días 16 al 24 de Octubre de 1909, Tomo Segundo (Buenos Aires: Campañía SudAmericana de Billetes de Banco, 1910), 370-71.

165. Jonathan D. Ablard, Madness in Buenos Aires: Patients, Psychiatrists, and the Argentine State, 18801983 (Canada: University of Calgary Press, 2008), 26. 
Figure 3.2: Casa de Niños Expósitos, Buenos Aires ${ }^{166}$

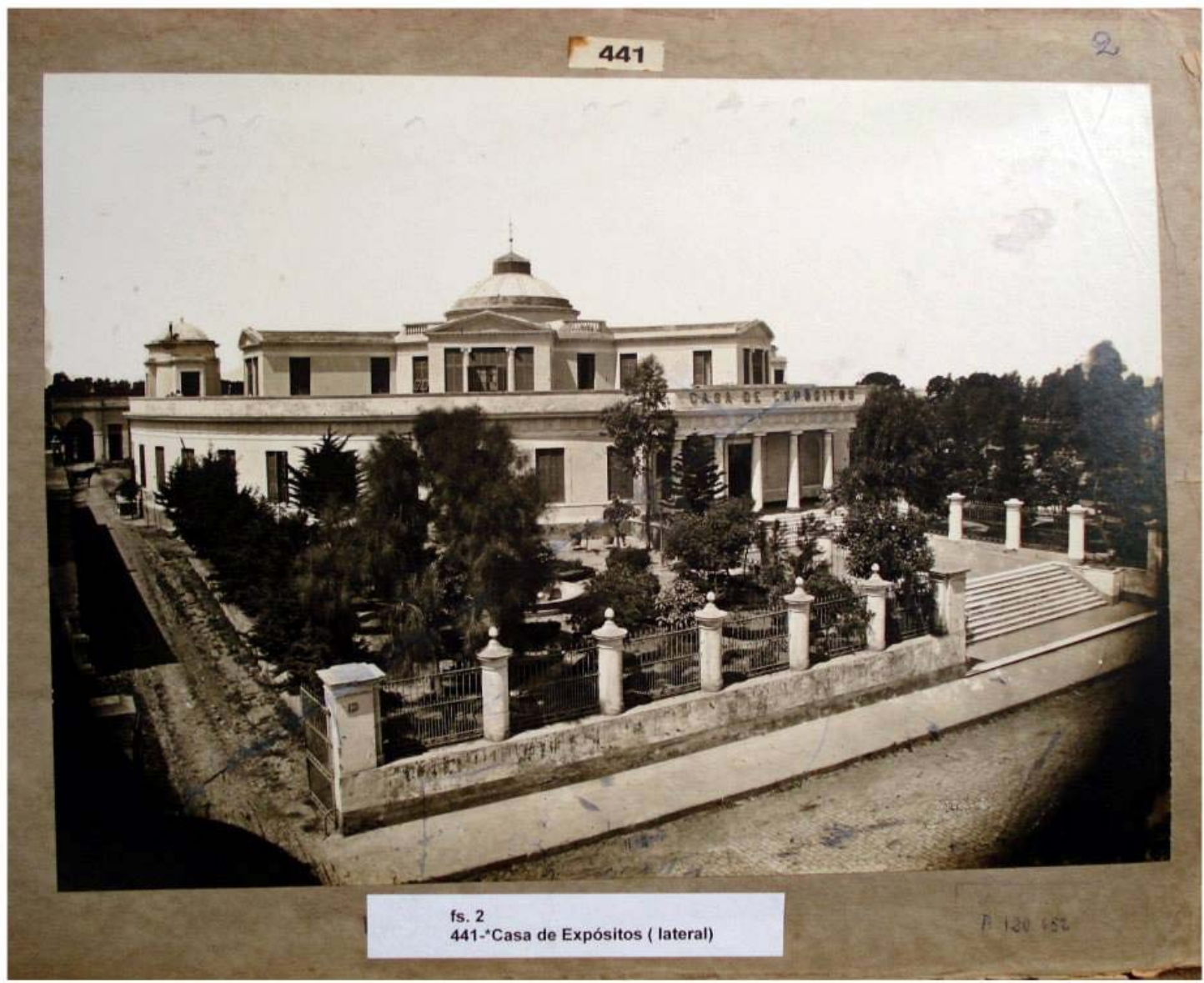

Historical architect Adrián Gorelik examines how public space shaped the city in his monograph La Grilla y el Parque. He explains that at the heart of urban transformation, late nineteenth century planners imagined parks -but separate parks - as spaces of reformation. Rather than have workers and immigrants assimilate within the elite parks of Palermo, professionals built a system of parks around the city in an effort to both define the boundaries of the modern city and reform its population through space.

166. Archivo General de la Nación Argentina (AGN), Colección Witcom, Documento fotográfico, Inventario 1260, Casa de Niños Expósitos fines del siglo XIX. 
The park began to function as the ideal mode of modern transformation, "as hygienic and civic regeneration and as a moral and economic umbrella." ${ }^{167}$ New parks also served to create boundaries between the elite and the other, serving to sanitize and civilize space. Journalists remarked on the elite's "Monopoly of Air" and desire to exclude the poor from Palermo. ${ }^{168}$

Parks, indeed, served the imagination of liberal elites as sanitizing the landscape of Buenos Aires and defining socio-economic boundaries. They provided new urban spaces for children and defined a space for authorities to lie out modern, state-directed, concepts and boundaries of childhood. Hygienists especially viewed parks as a place for children to enjoy healthy leisure activities, an escape from the perceived ailments of urban society, and civic socialization with peers. Children formed as an important, if not the most important, population for reform in the eyes of state and municipal authorities. Parks, and eventually playgrounds, served to define the boundaries of children's space and behaviors. They provided clear-cut spatial boundaries for children in urban public space, centering play as normative childhood behavior and restricting the activities of children acting outside of that normative behavior. The regenerative and reformative power of parks, coupled with similar concepts of leisure and physical culture, provided a space and a platform for elite authorities to produce a discourse of modern childhood in the name of a future modern citizenry.

167. Adrián Gorelik, La Grilla y el Parque: Espacio Público y Cultura Urbana en Buenos Aires, 18871936, La Ideología Argentina Ideología Argentina (Universidad Nacional de Quilmes) (Buenos Aires: Universidad Nacional de Quilmes, 1998), 165.

168. See article by La Vanguardia, a socialist newspaper, titled,“The Monopoly of Air”cited in Diego Armus, The Ailing City: Health, Tuberculosis, and Culture in Buenos Aires, 1870-1950 (Durham and London: Duke University Press, 2011), Loc: 4470 of 5640 


\section{Saving the Children}

In the first decades of the twentieth century, the growing visible presence of young working class children selling goods in the streets shed light on concerns over the ways in which children conducted themselves in public. Unsupervised children, participating in the increasingly busy streets of the city, were seen as unsafe and unsightly in the eyes of elite authorities. Dr. Enrique Feinmann examining the state of social hygiene in Argentina, remarks on street children in his paper at the Second Pan American Scientific Conference in 1915.

The population of street children is really extraordinary; there are a multitude of little ones 6-7 years old, peddling in the streets with various trades. Newsboys, messengers, shoe shiners, and lottery ticket vendors. A world of little people exposed to all the contacts and all the contagions of this miserable and immoral life.

Feinmann's observation of children working in public view reveals an important theme shared by physicians and politicians alike. Children were in need of protection from urban life. The streets of Buenos Aires, he imagined, harbored immorality and did not provide a safe environment for them. Feinmann's view of the "pathogenic" nature of the city was common amongst physicians of the time, and appears out of the late nineteenth century influence of criminological positivism. In this urban context, health and hygiene were intimately connected to questions of morality and behavior. Physicians and psychologists agreed that immorality was a significant social disease. "Immoral subjects” were thus categorically quantified and examined for physiological and psychological abnormalities. ${ }^{169}$ The dangers of exposure to immorality, imagined as

169. Maríana Angela Dovio, “El Caso de la 'Mala Vida’ en la Revista de Criminología, Psiquiatría y Medicina Lecal (1914-1927) en Buenos Aires: Entre La Peligrosidad y La Prevención,” Revista de Historia del Derecho, no. 43 (enero-junio 2012): 2-5. 
cultivating and spreading though out the streets of Buenos Aires, presented a problem for officials to contain and control within the urban environment. ${ }^{170}$

Language betrays some of these anxieties. Historian Caroline Zapiole writes on the distinguishing patterns that developed between the use of "niños" and "menores" from 1880 to 1920 in Buenos Aires. On the one hand, niños increasingly indicated children who met the established roles of modern society, particularly the role of the student. Zapiole references the Common Education Law, which established secular compulsory education, as representative of this modern ideal of childhood. Enacted in 1884, this law largely consolidated the efforts of the central liberal state to normalize the educational lives of children ages six to fourteen under state tutelage. On the other hand, menores, tended to represent those children that did not meet this ideal, but instead would likely end their education early to enter the work force, and especially delinquent or abandoned children. ${ }^{171}$

Elite anxieties over the dangers of menores are reflected in the daily police records of Buenos Aires in the first decade of the twentieth century. In 1906, police were ordered to enforce the Common Education law due to too many school-aged children,

170. Diego Armus, Health, Tuberculosis, and Culture in Buenos Aires, 1870-1950 (Durham and London: Duke University Press, 2011), Amazon Kindle E-Book; Kindon T. Meik, "Disease and Hygiene in the Construction of Nation: The Public Sphere, Public Space, and the Private Domain in Buenos Aires, 18711910,” Ph.D. diss., FIU Electronic Theses and Dissertations Paper 547 (2011) (Florida International University), Http://digitalcommons.fiu.edu/etd/547; Donna J. Guy, Sex and Danger in Buenos Aires: Prostitution, Family, and Nation in Argentina (Lincoln: University of Nebraska Press, 1991).

171. María Carolina Zapiola, "La Invención del Menor: Representaciones, Discursos y Políticas Públicas de Menores en la Ciudad de Buenos Aires, 1882-1921,” Tesis de Maestría (Buones Aires: UNSAM, 2007); María Carolina Zapiola, “Los Niños Entre la Escuela, el Taller y la Calle. Buenos Aires, 1884-1915,” Cadernos de Pesquisa, Fundaçao Carlos Chagas 39, no. 1 (Janeiro/Abril 2009): 69-81. 
"wandering the plazas and streets, ignoring their duty to attend school." ${ }^{\text {172 }}$ Pointing to the unwillingness of their parents or guardians to, the police cited the parent's names and addresses of children found in public view. In Feinmann's analysis into the state of social hygiene in Buenos Aires, he points to three factors he believed led to delinquency, immorality and this deleterious condition he described for laboring children in Buenos Aires: parental negligence, a poor environment in both the home and in the street; and a lack of disciplined education. ${ }^{173}$ Families were blamed for failing to provide adequate moral examples and supervision over their children. Elites turned to their fears of the immigrant parent to find the culprit for this spreading social and moral scourge. One way of coping was to diminish the authority of parents over their children. "Save the children and there will be fewer men to correct and punish,” Feinmann reiterates in his conference paper. $^{174}$

The rehabilitative power of the environment was also paramount to the social hygiene movement espoused by Feinmann and other physicians of the time. Where the healthy, hygienic home was lacking, it was up to the state to provide these spaces for the children of the city. Enrique Banchs, an Argentine poet and journalist, writes on the importance of providing a rural-like space to facilitate a child's connection to nature. Emphasizing the importance of state institutions for "weak" children, he describes the

172. AGN, Policia de la Capital, Órden del Dia, Volúmen XXV, TOMO II (1906), 801.

173. Enrique Feinmann, "La Medicina Social y Los Problemas Del Trabajo En La República Argentina,” Read by Dr. Sarmiento Laspiur, Joint session of Subsection C of Section VIII and the American Sociological Association, December 30, 1915 in Proceedings of The Second Pan American Scientific Congress, Section VIII, Part I Public Health and Medicine, Monday, December 27, 1915, to Saturday, January 8, 1916, chairman William C. Gorgas (Washington, U.S.A.: U.S. Government Printing Office, 1915), 568.

174. Feinmann, “La Medicina Social y Los Problemas Del Trabajo En La República Argentina,” 568. 
role of state intervention in family life. "The child is not only a son, but also a member of society... a citizen. It is evident that there is a social duty to ensure.” He further argues that the state should intervene "more and more in the education of children, whenever possible replacing the parents, who often lack the time, will and judgment” to lead them. ${ }^{175}$ Concerns over the state's ability to extend its reach over the many children at need, who so often left school early to enter the labor force, appeared as projects that would transform the Buenos Aires landscape. Directed at the menores of the city, nationbuilding projects aimed to improve the health and moral character of children by improving their social urban environment. The nature of a modern childhood increasingly centered on the child's instinct to play, however not all types of play were equal. Disorganized, spontaneous play for example was viewed with contempt and fear. The first Pan American Child Congress, organized by Argentine women, took place in Buenos Aires in 1916. Historian Donna Guy, in her examination of these conferences from 1916-1942, reveals how efforts to promote welfare states were fueled by the Pan American child rights movement. By the 1920s, the obligation to protect working women and children fell to government agencies. ${ }^{176}$ State authority thus grew over childhood, which was traditionally regarded as the domain of the family, in the first decades of the twentieth century. This is tied to neo-Lamarckian progressive thinking that reforming the social environment of children would improve the quality of future citizenry. Historians have linked these sorts of improvements to public health and

175. Enrique Banchs, “Escuelas para Niños Débiles,” Biblioteca Nacional de Maestros (Buenos Aires: El Monitor de la Educación Común. Consejo Nacional de Educación, 1909), 677.

176. Donna J. Guy, "The Pan American Child Congresses, 1916-1942: Pan Americanism, Child Reform, and the Welfare State in Latin America," Journal of Family History 23, no. 3 (0272-91 1998). 
infrastructure in Argentina under "social hygiene” reforms, viewed as preventative measures taken by government authorities to rid society of urban pathologies. ${ }^{177}$ The state's role in creating childhood institutions largely targeted abandoned, sick and delinquent children, in part because these were the children most in need, but also to serve the greater interests of producing - and controlling - more productive future adults. The discourse of rehabilitation and preventative medicine at the turn of the century contributed to the ways in which the government would deal with problems associated with childhood. Child welfare, thus, came under the direction of state and municipal authorities in order to ensure a healthier, more patriotic, future adult population. Child health and social reform, in this way, were tied to nation-state building and childhood acted as a measure of modernity.

Social hygiene efforts to "save the children" closely aligned with positivist criminology, in which reformers dictated that the most at risk children for delinquency belonged to the working classes. Coupled with the desire to assimilate - and civilize - the growing immigrant population, reformers encouraged “normalizing” institutions for at risk children within newly constructed recreational parks. Banchs reiterates this viewpoint, that "society wants its members to be healthy and the State wants Argentines that are strong."178 These state run institutions relied heavily on elite beliefs that transforming the child's environment and encouraging a physical culture of play would result in an ideal future population.

177. Particularly interesting is Lakoff's discussion of "The Social Organism," Andrew Lakoff, "The Simulation of Madness: Buenos Aires, 1903,” Critical Inquiry 31, no. 4 (Summer 2005): 853-57.

178. Banchs, "Escuelas para Niños Débiles.” 
Among the child welfare reforms tackled at early twentieth century congresses, the reduction of child labor appeared as one of the most important issues. Calls for child labor reform are actually intimately tied to play and recreation. It was a common belief that idleness encouraged bad behaviors, so some argued it was better for children to work than to get into trouble on the streets. At the same time, studies on child laborers revealed a plethora of problems that working caused on their physical and mental development. In a study presented at the Second Pan American Scientific Congress, the physical effects of labor on working children largely pointed to the susceptibility of disease. The report describes a number of ailments and illnesses caused to children by industrial labor and accidents caused by machines, highlighting that for an adult these trades would not be regarded as so dangerous. ${ }^{179}$ As child welfare reforms increasingly discouraged child labor in the name of health and hygiene, the demand grew for safe recreational space and productive ways for children to spend their time.

At the same conference, presenters discussed the need for more recreational space in city planning. They discussed the health benefits of open air and light and the need for a network of parks throughout the urban environment so that all could easily reach them. One presenter pointed to the redirection of immoral behavior through recreation. Rather than focusing most efforts on building jails, hospitals and asylums to contain "misapplied recreational endeavor[s],” McFarland suggests agencies focus on building playgrounds and recreational facilities to channel healthy recreational expenditure. Largely his

179. Owen R. Lovejoy, “Child Labor and Public Health,” Joint session of Subsection C of Section VIII and the American Association for Labor Legislation, Wednesday afternoon, Decebmer 29, 1915 in Proceedings of The Second Pan American Scientific Congress, Section VIII, Part I Public Health and Medicine, Monday, December 27, 1915, to Saturday, January 8, 1916 (Washington, U.S.A.: U.S. Government Printing Office, 1915), 276-78. 
reasoning is that if these "wholesome" facilities are not provided by cities or the nation, recreation will be provided commercially "by the forces of evil,” causing disorder. ${ }^{180}$

\section{The Playground Movement}

In 1898, Pablo Pizzurno, an educator and major proponent of physical education in Buenos Aires, remarked on the deficiencies of the youth; he pointed to their lack of morals, aspirations and seriousness. After writing at length on the horrors of the youth, Pizzurno posed a rhetorical question - Why, if children are reading and listening to lectures on moral and civic instruction books, are they not applying this in their lives? His answer - children cannot study morality like they do for an exam. ${ }^{181}$ Educators and urban reformers in Buenos Aires pushed for physical and recreational activity to develop ideal morals in childhood. Play was even posited as a preventative measure to crime, and promoted as a natural activity to improve moral behaviors.

Early nineteenth century Argentine educators recognized the importance of physical education and promoted classical, rigorous military routines and gymnastics in order to build strong, disciplined future adults. Typical nineteenth century instruction manuals on physical exercise show a controlled performance of movement, requiring rhythmic and aerobic skills. Military exercises were the norm in nineteenth century elite classrooms, as these regimented lessons of physical exercises and endurance were

180. Horace J. McFarland, “The Human Side of City Planning,” Joint session of Subsection D of Section VIII and the American Civic Association, December 30, 1915 in Proceedings of The Second Pan American Scientific Congress, Section VIII, Part I Public Health and Medicine, Monday, December 27, 1915, to Saturday, January 8, 1916 (Washington DC: U.S. Government Printing Office, 1915), 385-87.

181. Pablo A. Pizzurno, “Deficiencias de la Educación Argentina: Algunas Causas y Remedios,” La Educación XIII, no. 275 y 276 (Marzo 1 y 15 1898): 38-39. 
believed to build strong future men. Photos of common schools in Argentina often depict school battalions of students lined up in military form (See Figure 3.3).

Figure 3.3: Batallones Escolares, $1889^{182}$

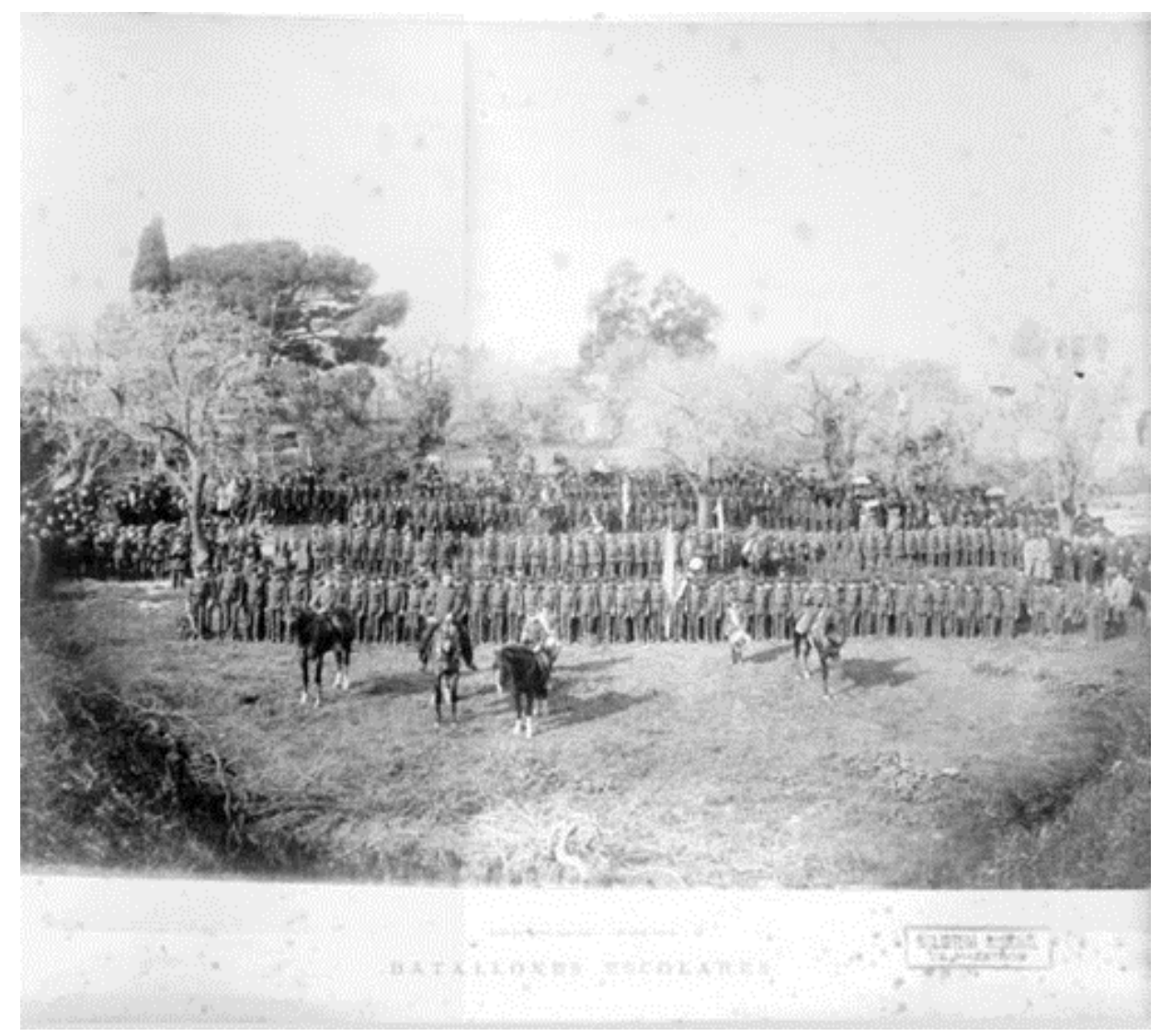

In an 1884 Buenos Aires publication by the National Council of Education, El Monitor de la Educación Común, gymnastics is applauded for improving physical development in a variety of ways, from building muscles and creating more agile joints to improving overall digestion and blood circulation. Additionally, the author pointed out that the utility of gymnastics extended beyond physical strength and inspired courage to

182. Samuel Boote, "Batallones Escolares,” Vistas de escuelas comunes. Buenos Aires : Consejo Nacional de Educación, Biblioteca Nacional de Maestros (1889), 39. 
attempt daring acts, while forming a resolute mind in the execution of those acts. ${ }^{183}$ Strength and discipline marked the ideals of physical exercise to build strong courageous national bodies of students, well into the late nineteenth century.

Just five years later, however, El Monitor published another article criticizing classical gymnastics and military exercise in schools, calling for a more "natural" approach for children. Felipe Daryl, the French author of the article, writes on the theory and practice of games and sport, pointing to two theories of physical education, the system of traditional regimented exercise and a new system of exercise consisting of recreation and play." ${ }^{184}$ Daryl examines two national systems of physical education to conclude that the latter system of play proved superior to classical forms of exercise. Daryl compares France, representing the doctrinal practices, and England, representing the new model of play. He argues that in England, children, particularly of the peasants and working class, do not have classical gymnastic equipment, yet yield a stronger population. The youth of France, by comparison, with full gymnasiums and regimented programs of exercise in schools and colleges, lacked the robustness of the young people in England. Daryl argues that "natural” play in childhood, using simple games and exercises, builds a “more robust, happier, and more dexterous man." ${ }^{185}$ Most importantly, Daryl posits that these activities, such as jumping, running, hitting, throwing and rowing, with objects such as ropes, paddles, balls and tree trunks, do not belong to any particular

183. BNM, “La Utilidad de la Gimnástica,” El Monitor de la Educación Común 3, no. 59 (Mayo 1884): 593-94.

184. BNM, Daryl Felipe, “La Gimnástica Natural,” El Monitor de la Educación Común 11, no. 149 (ene. 1889): 421-23.

185. Felipe, “La Gimnástica Natural,” 422. 
class. He equates this to a more natural state of childhood play, positing that "the savage has no other apparatus, and animals do not have classes." ${ }^{\text {"186 }}$ For Daryl, and proponents of play in Buenos Aires and cities around the world, a broader approach to physical education was necessary to reach the urban masses.

Coupled with the utility of building a strong military and the largely elite nature of education of the post-colonial era, classical and rigorous military exercise formed the tenet of "recreational" activities in building the nation-state. Yet, by the end of the century, definitions of childhood recreation changed. Pedagogues encouraged children to play outdoors, free to exercise and explore nature though self-activity. The focus shifted, and the discourse on modern childhood recreation aimed to improve children's overall health and morality. Modern childhood physical education was tied to both burgeoning child development studies and a desire to improve the condition of the population, to encourage disciplined, moral civic-minded adults.

A Pan American play movement in the first decades of the twentieth century largely influenced the play movement that developed in Argentina. The Playground Association of America formed in 1906, rooted in the tradition of improving physical fitness, inspired by German and English proponents of recreation. ${ }^{187}$ Proponents of the play movement argued that the physiological and psychological experience of the playground shaped future democratic behaviors of citizens and improved the moral and social fabric of childhood. Throughout the Americas, play and playgrounds were closely

186. Felipe, “La Gimnástica Natural,” 422.

187. Joe L. Frost, A History of Children's Play and Play Environments: Toward a Contemporary ChildSaving Movement (New York: Routledge, 2010), 103-05. 
associated with modern education, and playgrounds were developed in public schools and city parks. Urban social reformers in the United States urged municipal governments to construct playgrounds to move control of play from the family to the state. This was aimed particularly at immigrant families. Urban social reformers sought to develop a modern American childhood to condition the twentieth century adult citizen. ${ }^{188}$

The Pan American stage increasingly provided scientific standards to measure modernity, by which health and education could be measured, and "normal” definitions of childhood could be drawn and compared. In Argentina, as was true in the United States and Europe, early twentieth century reformers increasingly encouraged the development of spaces of organized play, such as public gardens, playgrounds and museums, as solutions to many perceived urban problems affecting children. Efforts to improve the living conditions and general welfare of children formed part of a broader child-saving movement aimed at urban environments around the world. Progressive era reforms in the United States, for example, included provisions for "public physical welfare" and "artificially made” rural space in the cities, as well as "directed or supervised play.”"189 Urban reformers, frustrated with the overcrowded and unsanitary conditions of cities, often looked nostalgically at the rural environment as a bastion of health. Provisions for hygienic spaces of recreation were also part of the child-saving

188. For a detailed analysis of the Playground Movement and urban childhood in the United States, see Cavallo Dominick, Muscles and Morals: Organized Playgrounds and Urban Reform, 1880-1920 (Philadelphia: University of Pennsylvania Press, 1981).

189. In the chapter, “The Early Child-Saving Movement: Shame of the Cities,” Frost provides an introduction to early Progressive era American influences of the child-saving movement. Frost, A Hisotry of Children's Play, 62-63. 
movement, aimed at providing the necessary conditions for good health and proper hygiene, while simultaneously redirecting the “dangerous” youth population. ${ }^{190}$

The call to redirect play away from family models was highlighted in the Annual Playground Congress of 1908. One proponent of child labor restrictions notes the concerns over the rights of the family and the perception that the state should not intervene between the parent and the child. The presenter argues that the protection of the child trumps parental rights, especially when their "natural protectors" regard children for their financial gain at work. ${ }^{191}$ He goes on to define play at the center of childhood, stating that children denied play are "completely deprived of the universal right of childhood.”192 Coupled with restrictions on labor, supervised playgrounds provided the best solution to child labor, "as the most effective reply to the objector who considers the children better off in the factory than on the street”193 A modern Pan American twentieth century childhood was increasingly defined as one filled with play. In a 1920 article against child labor, the author posits that "the business of children is to be children- this involves an abundance of play - and to grow up into healthy, intelligent, moral and efficient citizens."194 The necessity to construct a supervised environment for children’s

190. Everett B. Mero, ed., American Playgrounds: Their Construction, Equipment, Maintenance and Utility (New York: The Baker \& Taylor Co., 1908), 15, 17.

191. E. W. Lord, “The Playground A Necessary Accompaniment to Child Labor Restriction,” Third General Conference, Wednesday Morning, September 9 in Proceedings of the Second Annual Playground Congress, September 8-12, 1908 (New York City: Playground Association of America, 1908), 122.

192. Lord, “The Playground,” 125.

193. Lord, "The Playground,” 126.

194. “Child Labor Vs. Recreation,” The American Child: A Quarterly Journal of General Child Welfare 2, no. 1 (May 1920): 9. 
play was posited as just as crucial to the child's development as removing children from labor.

Pedagogues and physicians agreed that children were meant to play, however not all play was equal. The fear that unsupervised or spontaneous play led to general disobedience and delinquency was apparent in Buenos Aires police records. Police daily orders indicated that strict rules were enforced against certain types of "play” that too closely resembled labor or caused public disturbances. For example, in 1902, children were prevented from playing brass instruments in "public view,” and just months later, police were ordered to more strictly enforce laws against begging in the street. ${ }^{195}$ Police also increased surveillance to reduce the number "widespread" occurrences of children playing with slingshots in public view. ${ }^{196}$ Authorities defined certain types of play as inappropriate or inconvenient to city life. Child development theories suggested that organized play provided the best environment for the physical development and health of children, thus producing better rounded future citizens. A number of Pan American manuals and handbooks for mothers and teachers were produced with instructions on how to guide children's play. These guides purported organized play for all sorts of ailments: the reduction of childhood disease, improved mental and physical capacity, the development of democratic social values, and the prevention of delinquency. ${ }^{197}$

195. AGN, Policia de la Capital, Órden del Dia, Volúmen XXI, TOMO I (1902), 704, and TOMO II (1902), 1108.

196. AGN, Policia de la Capital, Órden del Dia, Volúmen XXI, TOMO II (1902), 1364.

197. George B. Magold PhD, Child Problems (New York: The Macmillan Company, 1914), 95-102. 
Physicians linked the improved physical condition of children to an improved moral condition. Writing as the former Secretary of the New York Committee on Physical Welfare of School Children, William H. Allen, explains the connection between play and moral development. ${ }^{198}$ He posits that muscular development alone, through traditional physical training, was not sufficient. Games and play in the open air, he argues develops more than just the body, but also develops the mind and morals. For Allen, "adults have forgotten to leave space in cities" for children to do what they naturally are inclined to do, that is to play. Further, with children entering the work force so young, they do not have to time to play appropriately. ${ }^{199}$ To demonstrate his point, Allen tells the story of a young girl who cares for her mother and two younger siblings. She does all the housework and prepares the meals. Allen argues, in this case, the girl does not need any more physical training. Instead, she needed "playmates, open air, a run in the park and 'fun.”,200 Efforts to reduce the labor load of children, but not necessarily the work of children, were part of the larger Pan American child-saving movement. The visible shift towards identifying play as "natural" to childhood appeared in pedagogical guides across the Atlantic in the first decades of the twentieth century. A debate surged in Buenos Aires over which types of physical activities proved most effective in developing a healthy, moral childhood. While some called for state directed physical education, conceived as a public service and necessary function of the state, others criticized placing the care of children's health and well being in the state's

198. William H. Allen, Civics and Health (Boston: Ginn and Company, 1909), 117-18.

199. Allen, Civics and Health, 117-18.

200. Allen, Civics and Health, 119. 
hands. In an 1890 critique of the state of physical education in Argentina, the family is posited as the best provider for physical and moral education. The author reflects on the inability to measure, with accuracy, the effect of regulatory physical education on the culture and morality of the child, but argues that the public school system and educators in Argentina failed to provide the physical and moral development of the individual. The author warned that if childhood exercise continued to be regulated and managed by schools, the result would be a weakened race and nation. Play and recreation, thus, was best suited in the care of family, to the home where children spent most of their days. ${ }^{201}$

The layout of the domestic interior visibly shifted towards a growing belief that play was natural to childhood, and that parents should provide a place for children to play within the home. Homes of the privileged class incorporated patios, gardens and terraces to provide large leisure spaces in the open air and sun. ${ }^{202}$ Yet, the crowded conventillos of the poor did not provide these domestic spaces, and thus fueled the call for more public spaces of leisure. Fear of an increasingly weakened nation through immigration also fueled the state's interest in developing physical education programs and playgrounds within the city. Historian, Diego Armus, in his examination of physical exercise and tuberculosis, points out that this fear also encouraged exercise for girls, though much debated. While girls were long discouraged from exercise, proponents focused on their future maternal role, arguing that girls needed exercise to prepare their bodies for healthy pregnancies and future motherhood. The "nature" of childhood, in this

201. “Educacion Fisica: Los Recreos de los Niños,” El Monitor de la Educación Común Año XI, no. 184 (15 Julio 1890): 241-42.

202. See many examples of domestic interiors within Revista de Arquitectura, 1924-1928, available at Wolfsonian-FIU archives, Miami, FL. 
case distinguished by gender, formed the discussion of scholars at the turn of the century. The call for girls to participate in physical education, in order to nourish their natural role in the nation, fit well with the state's scientific approach to building a modern nation. ${ }^{203}$

In the first decades of the twentieth century, Ernesto Nelson, one of the most prolific supporters of building playgrounds Buenos Aires, believed the new spirit of education included a "modern” pedagogy of self-activity in the urban environment, an idea that was already being implemented in kindergartens and primary schools. He encouraged, for example, trips to museums, gardens, monuments or the beach, to connect childhood education with the "the world of concrete things." 204 These activities allowed children to observe, compare and make conclusions on their own, training the senses and building reasoning skills, significant, he argued, in both childhood and adulthood.

Nelson exemplifies the Pan American spirit of the play movement. Echoing the sentiments of Daryl, Nelson often spoke harshly of higher systems of education and suggested that secondary schools and universities focused too much on the preparatory nature of "knowledge-getting" rather than the development of the individual character for a lifetime of learning and performance. The preparatory nature of forming the future adult was still paramount, however the nature of educational practices surrounding childhood was questioned. In a presentation at the second Pan American Scientific Congress in 1915, Nelson acknowledged the privileged nature of higher education, and

203. Armus, Health, Tuberculosis, and Culture in Buenos Aires, Loc: 3882-932 of 5640.

204. Ernesto Nelson, “The Secondary School and The University,” General Session of Section IV, January 5, 1916 in Proceedings of The Second Pan American Scientific Congress, Monday, December 27-1915 to Saturday, January 8, 1916, Part 2 Education, ed. Glen Levin Swiggett (Washington, U.S.A.: U.S. Government Printing Office, 1917), 183. 
argued that limiting childhood education to the university model of memorization and standardized testing in order to achieve state education was a wasted opportunity in a democratic society. All children, he argued, should have access to a free modern education. "No price would be asked for such service," he argued, "whose real recipient is the nation at large., ${ }^{205}$

Nelson visited the United States many times, often expressing his interest in their playgrounds and outdoor recreational organizations, such as the Boys Club. He encouraged a positive relationship between Argentina and the United States, and even invited U.S. teachers to exchange educational materials with him in Buenos Aires. In 1908, he started a campaign for children of Argentina to correspond with other children in the United States. Nelson's plans for children to exchange letters, photographs and other materials took part in his greater aspiration for stronger diplomacy between the United States and Argentina. The exchange program also correlates with pedagogic interests to teach students Argentine history and geography as a separate subject from world history. ${ }^{206}$

Nelson viewed the United States and Argentina as quite similar, and at times grew aggravated when people of the United States did not recognize Argentina as a modern, independent nation. At the Washington Pan American Congress, Nelson was asked, "How much more do the people of the United States know about the people of South

205. Nelson, “The Secondary School and The University,” 180.

206. Hobart A. Spalding Jr., "Education in Argentina, 1890-1914: The Limits of Oligarchical Reform,” The Jornal of Interdisciplinary History 3, no. 1 (Summer 1972): 42. 
America now than when this congress began two weeks ago?"207 He responded, aggravated, "It is your use of the definite, significant name of your own country, coupled with the vague, meaningless geographical term that you seem to think will sufficiently classify mine,” and continued to explain that the United States must learn there are many “South America” nations. ${ }^{208}$ He describes the many similarities between the United States and Argentina, reminding that he speaks for his country, "not all of South America,” from political issues after civil war to social problems caused by immigration. He details many things that the United States "should know about the Argentine Republic,” including its rich culture of art, music and literature. ${ }^{209}$ Nelson commanded a respect for the Argentine nation in his response in Washington, and this sense of national pride echoed in much of his works on education in Argentina.

Nelson's encouragement of children's correspondence between the U.S and Argentina further reflects his efforts in education to cultivate Argentine citizenship. He imagined the cultural exchange to create a positive future diplomatic relationship, but also better define Argentina as a nation to other countries. In the invitation, published in New York's Normal Instructor, it was noted “a better understanding of other countries will be obtained and these children will be more willing to consider arbitration as a means for settling international differences when they become old enough to take part in

207. "What We Don’t Know About South America: Dr. Ernesto Nelson of Argentina Points Out Many Common Interests and Talks of the Art and Literature with Which We Are Unfamiliar," New York Times, 16 January 1916, SM7.

208. "What We Don’t Know About South America,” SM7.

209. "What We Don’t Know About South America," SM7. 
the government."210 Clearly, Nelson hoped to shape not only the future minds of Argentina, but also those of the United States.

For Nelson, who served various positions for the Argentine Council of Education, and other proponents of self-activity and play, education should not end at childhood; rather they imagined the continuation of practical physical education throughout one's life. Nelson said he thought the slogan of education should be, "Let us train, and let knowledge take care of itself.”211 He urged universities and secondary schools to encompass the pedagogical practices of kindergartens and primary schools, citing secondary education as anachronistic and favoring memorization of specific information over self-activity and discovery. ${ }^{212}$

Nelson viewed the state's role in providing physical recreation as essential to the development of the nation and encouraged a pedagogy of play to be included in school curricula. He also wrote extensively about the development of public spaces of recreation, including playgrounds and museums. Increasingly, municipal authorities institutionalized play at the center of childhood in Buenos Aires, declaring the state's role in providing free playgrounds and gymnasiums for the children and youth of the city. In 1900, one such decree described the necessity to fulfill this "demand of the era” for the health of the child. It further explained, the state's role in fulfilling this need was to prepare them for the child's future service to the nation, an adulthood described as

210. “Exchange of Children’s Correspondence,” Normal Instructor XVII, no. 9 (September 1908): 7.

211. Nelson, “The Secondary School and The University,” 182.

212. For more on Nelson's criticisms of the Argentine university system, see: Alejandro Herrero, "Liberalismo y Democracia en Argentina. El Estudio de un Caso: Ernesto Nelson: ¿Un Educador del Estado en Contra del Estado?” Utopía y Praxis Latinoamericana 11, no. 33 (abril-junio 2006): 103-08. 
arduous and full of struggle, in which strength was paramount. ${ }^{213}$ The 1909 Buenos Aires census highlights the changes made to physical education in the first decade of the twentieth century. In a collage of images, both boys and girls are depicted “playing” and practicing sports outside. A caption for a picture of boys conducting classical gymnastics, placed in the center of the collage, reads “Today Abolished,” demonstrating the superiority and acceptance of children's play to past methods of physical exercise. ${ }^{214}$ The government included play in the official school curriculum, while also funding student excursions to parks, museums, and the zoological gardens. ${ }^{215}$ These efforts introduced children to the state's official history and provided a public stage to indoctrinate the youth with an imbued sense of Argentine nationalism.

Ernesto Nelson offered his recommendations for the development of playgrounds in Buenos Aires in his work, Plaza de los Juegos para Niños. ${ }^{216}$ "If you wish for the youth to take a moral life, do not neglect their pleasures"217 Nelson argues that

213. Julio Roca, "Decreto Declarando Que los Gimnasios y Plazas de Juegos, Que Se Están Construyendo, Se Encuentran Comprendidos en la Exoneración Que Determina la Ley N²927,” Boletin de Obras Públicas de la República Argentina, Publicación del Ministerio de Obras Públicas, Tomo I, Num. I (Buenos Aires, 1900), 501.

214. Don Manuel J. Güraldes and Martinez, Censo General de la Ciudad de Buenos Aires, 343.

215. Spalding Jr., “Education in Argentina, 1890-1914,” 36-37.

216. Interestingly, Historian Roberta Park pointed to the similarities between late nineteenth century scholars and today's calling for "play, games and physical training” for physical and psycho-social health in children in the United States. Park examines lesser known scholars of the late nineteenth century, and even dedicates a few sentences to Ernesto Nelson's work on playgrounds, Las plazas de juego para niños, due to his heavy involvement in the American Playground Association. Roberta J. Park, "'Boys' Clubs Are Better Than Policemen's Clubs': Endeavours by Philanthropists, Social Reformers, and Others to Prevent Juvenile Crime, the Late 1800s to 1917,” The International Journal of the History of Sport 24, no. 6 (June 2007): 749-75.

217. Ernesto Nelson, Las Plazas de Juego para Niños, Extracto del Museo Social Argentino (Buenos Aires: Imprenta y Casa Editora de Coni Hermanos, 1913), 3. 
playgrounds are an absolute necessity for healthy childhood development in the city, and states "it is essential to their developmental process that turns a child into an adult."218 Nelson encourages play through self-activity, particularly when it comes to the objects that children play with. His objective is to encourage and inspire originality, to provide children with simple goods that can be transformed by the child's imagination. For example, he states, "a hair brush wrapped in cloth makes an excellent doll."219 However, for Nelson, play could not be confined to the home. Social development was regarded as an important aspect of the playground, for both its moral and physical development. Open space was essential, and the proximity of the space to the home and school was also important, especially for the urban poor. Nelson's insistence for public supervised playgrounds, over play in the home, was significant for the use of playgrounds as a tool for social education and control.

\section{Palermo de los Pobres}

The conceptualization of play at the center of childhood also shaped child-saving efforts. The regenerative -sanitizing - power of green space, coupled with the rehabilitative power of play, served as a state solution to urban problems that were perceived to threaten the future of Argentine society. While the playground served as an essential tool for physical development and socialization in the urban world, it was also prescribed as a preventative and rehabilitative tool against physical weakness and immoral behavior. Several state run institutions were developed for children that were deemed "weak," either physically or mentally. The institutions were rehabilitative in

218. Nelson, Las Plazas de Juego, 8. 219. Nelson, Las Plazas de Juego, 13. 
nature, and the parks served as auxiliaries to the institution's goals to ready the children for the "normal” public education system. Playgrounds served also as an important deterrent of criminal behavior, providing clear spatial and behavioral boundaries for children to be seen in public.

Parks were constructed in the southern barrios of Buenos Aires, intended to provide recreational space to the laboring classes in the area. Planning efforts to transform the national imaginary of the southern region involved not only creating new public green space, but also by sanitizing the past. For example, a cemetery, Cementerio del Sud, just southwest of Constitución (today in Barrio Parque Patricios) met its capacity during the yellow fever epidemic, and was closed in 1871. A monument was erected in honor of those who died in the epidemic in 1872. By 1887, plans were submitted to the municipal council to turn the cemetery into a public park, citing that it would provide "great hygienic services to a significant part of the population of the capital.”220 Years later, most of the bodies were exhumed and relocated, and the space was renamed Parque Bernandino Rivadavia. ${ }^{221}$

The largest park in the region, Parque de los Patricios, broke ground on Arbor Day in 1902 on the site of the once largest slaughterhouse in the city (See Figure 3.4). Until the beginning of the century, this area was one of the most unsightly and malodorous of the city, being located also near the garbage incinerator.. According to Caras y Caretas, thousands of children were present at the inauguration's festival, helping to plant the trees and singing in chorus. Mayor Adolfo Bullrich (1898-1902)

220. Crespo, Censo General de la Ciudad de Buenos Aires 1887, 116.

221. Known today as Parque Florentino Ameghino, the park was renamed again to this in the 1920s. 
spoke at the inauguration and deemed the park an effort to "avoid diseases," reiterating the hygienic - sanitary - nature of the new space. ${ }^{222}$ However, Bullrich’s concerns to avoid disease also reveal the larger effort to "other" the southern barrio and prevent the spread of disease. Like the Parque de Palermo, Carlos Thays too designed Parque de los Patricios, but unlike Palermo it was created especially for the stigmatized region. While concerns over the health and morality of the barrio's children laid at the forefront of much of the discourse on reform, the park designated a separate space for the poor. The socio-spatial boundary created for the poor in this new park made it easier for elites to deny a working class presence in their social spaces in Palermo.

Playgrounds for the poor also helped to other children who deviated from what was considered "normal” childhood. Children who were not regularly supervised students often fell outside of this norm. The playground served as a space for the state to implement social policies to intervene in and redefine childhood for these children. Ernesto Nelson argued that the problem of juvenile delinquency largely rested on the desire to play and that juveniles' presence in the courts could be traced to a play-impulse for which there was no safe outlet. He argued "playgrounds should be located in the part of towns where juvenile delinquency is most frequent."223 ${ }^{, 22}$ Playgrounds provided a supervised - civilized - space and acted as a preventative measure to decreasing juvenile crime. In 1902, the municipal council made plans to add a playground to the park, which served as an auxiliary for other child-saving institutions to be implemented.

222. Quoted in, Armus, The Ailing City, Loc. 4469 of 5640.

223. Nelson, Las Plazas de Juego, 48. 
Figure 3.4: Parque de los Patricios Plans, $1902^{224}$

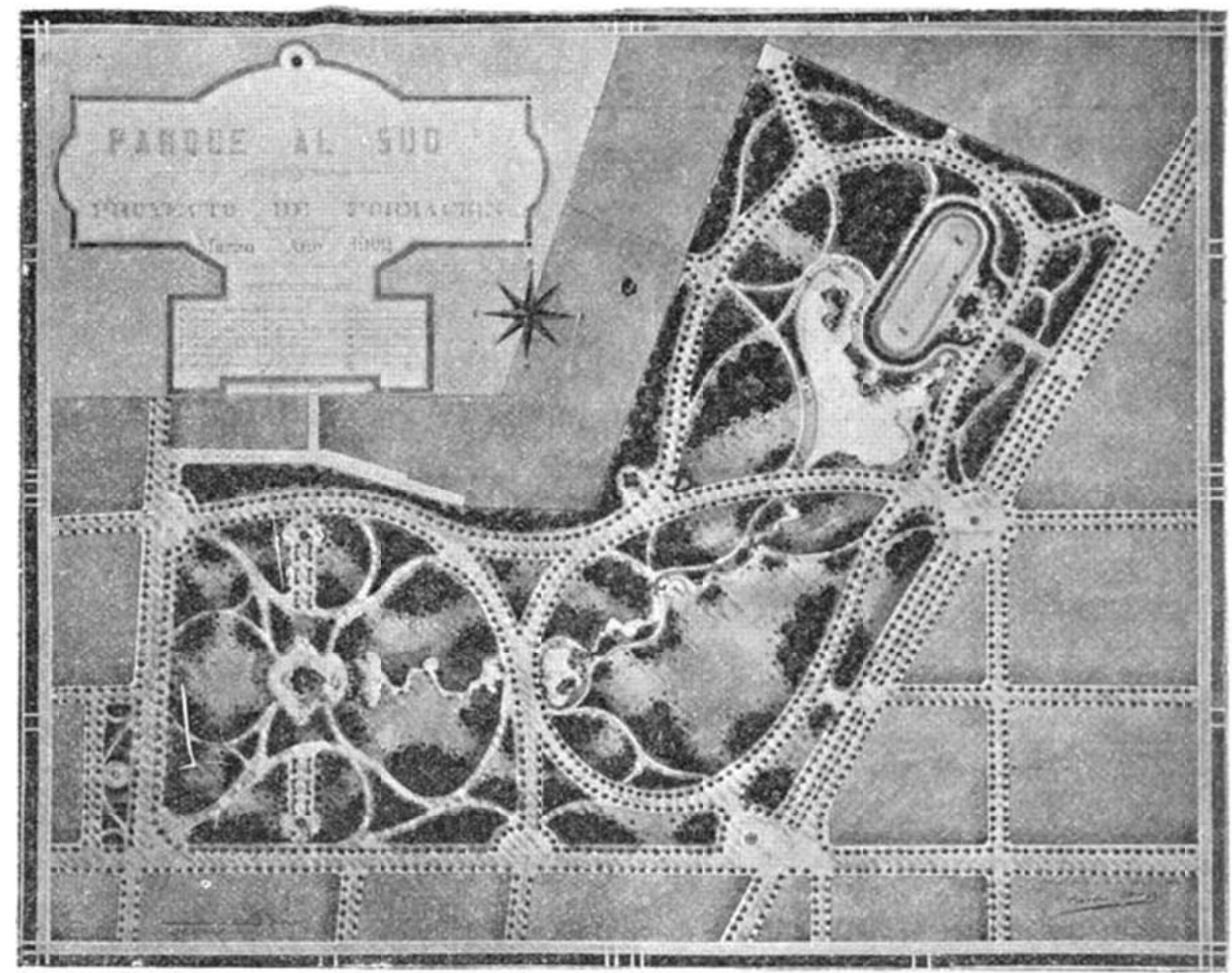

The Patronato de la Infancia, an institution founded in 1892 by the city of Buenos Aires to protect poor young children, built the first school in the park, aimed at reaching the region's poor and largely homeless child population in 1907. The school served more than 1300 boys and girls in the first year it was open. The school's curriculum included academic and moral lessons, practiced hygiene and physical exercise. ${ }^{225}$ A series of rare

224. ”Parque Al Sud,” Foto de Caras y Caretas, "Plano del Nuevo Parque,” Caras y Caretas V (20 de Septiembre 1902).

225. “Los Chicos de la Quema,” Caras y Caretas 11 (3 de Octubre 1908): 522-23. 
photographs of the school were printed with a 1908 Caras y Caretas article titled, "Los chicos de la quema," and aimed to show the positive effect the Patronato had on the barrio. The first photo reflects the condition of the children before the school was built. It features about 15 soiled boys standing in the street, wearing tattered clothing and shoes (See Figure 3.5). The article describes the children as knowing no home other than the street and surviving by eating trash out of the garbage. ${ }^{226}$ A series of photos follow revealing noticeably improved conditions and appearances of the children. The first features a classroom of dozens of boys, appearing neatly dressed and clean, seated in rows (See Figure 3.6). The article clearly demonstrates that the park and Patronato provided improved hygiene and gave the children a more orderly appearance. In another photo, the boys are lined up to receive a daily ration of milk and bread, contrasting the imaginary of children eating garbage.

Another set of photos demonstrates various methods of rehabilitation through physical work. Girls are featured learning to sew, as many girls typically would be placed in domestic service. Another series shows the boys exercising and organized play in the park, emphasizing the dominant theory of the time that play and exercise were essential to improving their condition (See Figure 3.7). The author of the article exclaims, "God has come down to Parque de los Patricios" and praises the work that the Patronato has done. ${ }^{227}$ Without the school, the author surmises many of the children would be dead or would have fallen into criminal behavior. The children, provided with

226. “Los Chicos de la Quema,” 522-23.

227. “Los Chicos de la Quema,” Caras y Caretas 11 (3 de Octubre 1908): 522. 
a hygienic park and a school run by the state, are featured as healthier and in considerably better condition than before the institution intervened.

Figure 3.5: “Chicos de la quema” before Parque de los Patricios ${ }^{228}$

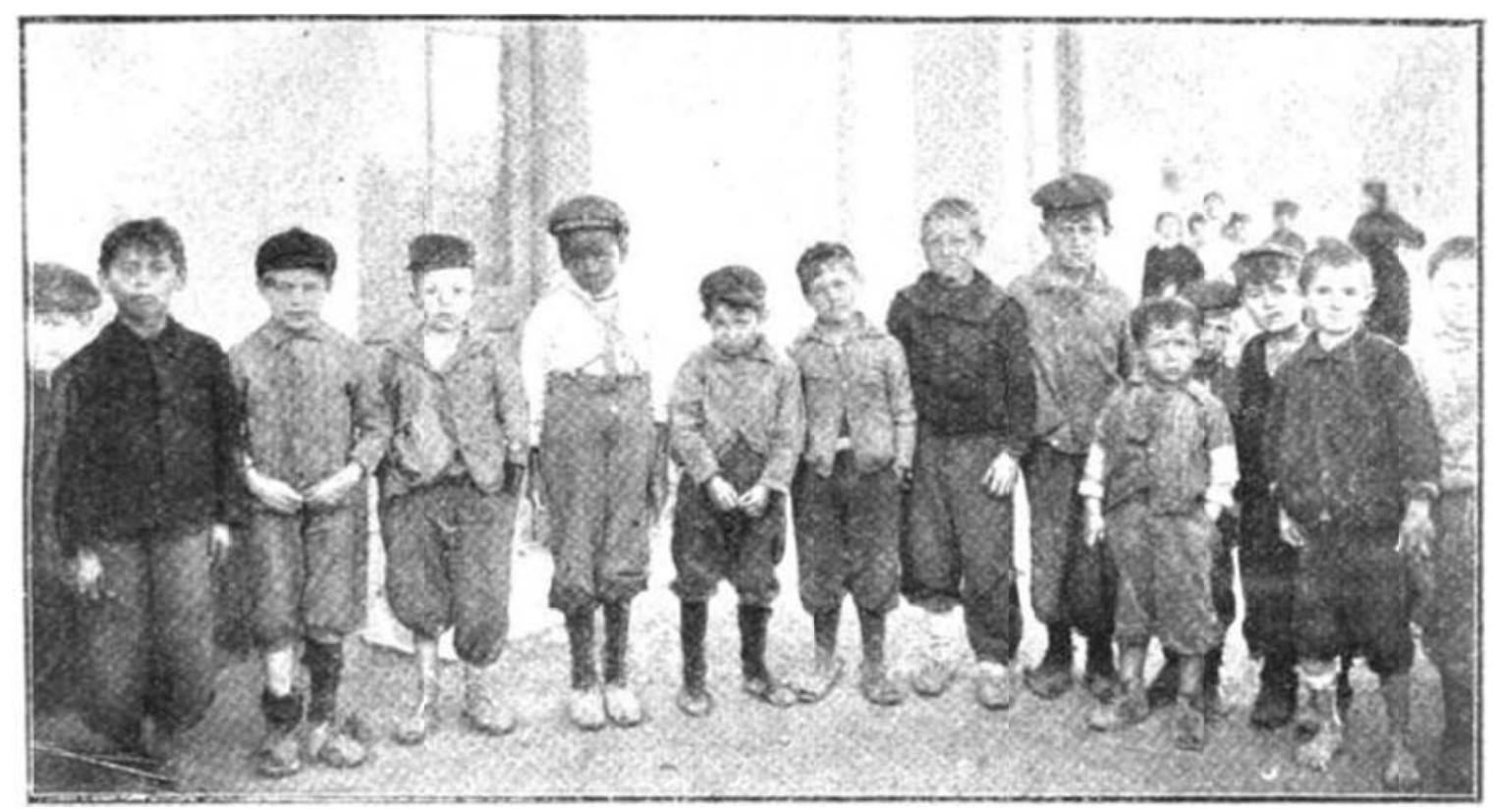

Establishing and defining a "normal" childhood can be viewed through the lens of the state's institutions established for abnormal children. Another school was established in a nearby park, Parque Lezama, just east of Plaza Constitution. The property for the park was acquired by the city in 1894, and like Parque de los Patricios, Lezama was also referred to as a Palermo de los pobres. The city turned the property's gardens and home into a park and national historical museum. The school that was established was an openair school for "weak” children, la Escuela para Niños Débiles del Parque Lezama. Openair schools provided many of the hygienic benefits considered essential to a healthy

228. "Los chicos de la quema con su indumentaria habítual antes de la transformación que ésta sufre en la 'Escuela Patria' del Patranato de la Infancia, establecida en el Parque de los Patricios," Foto de Caras y Caretas “Los Chicos de la Quema,” 522. 
childhood and were discussed widely at conferences on school hygiene. The fresh air and sunlight of "recreation grounds, gardens, stations, playgrounds and squares" made these excellent auxiliaries to open schools in areas of dense population. ${ }^{229}$ In fact, the benefits found in the many experimental open-air schools, including those in Argentina, led to reforms to increase the size of school buildings and improve their ventilation. ${ }^{230}$

Figure 3.6: Escuela Patria classroom, $1908^{231}$

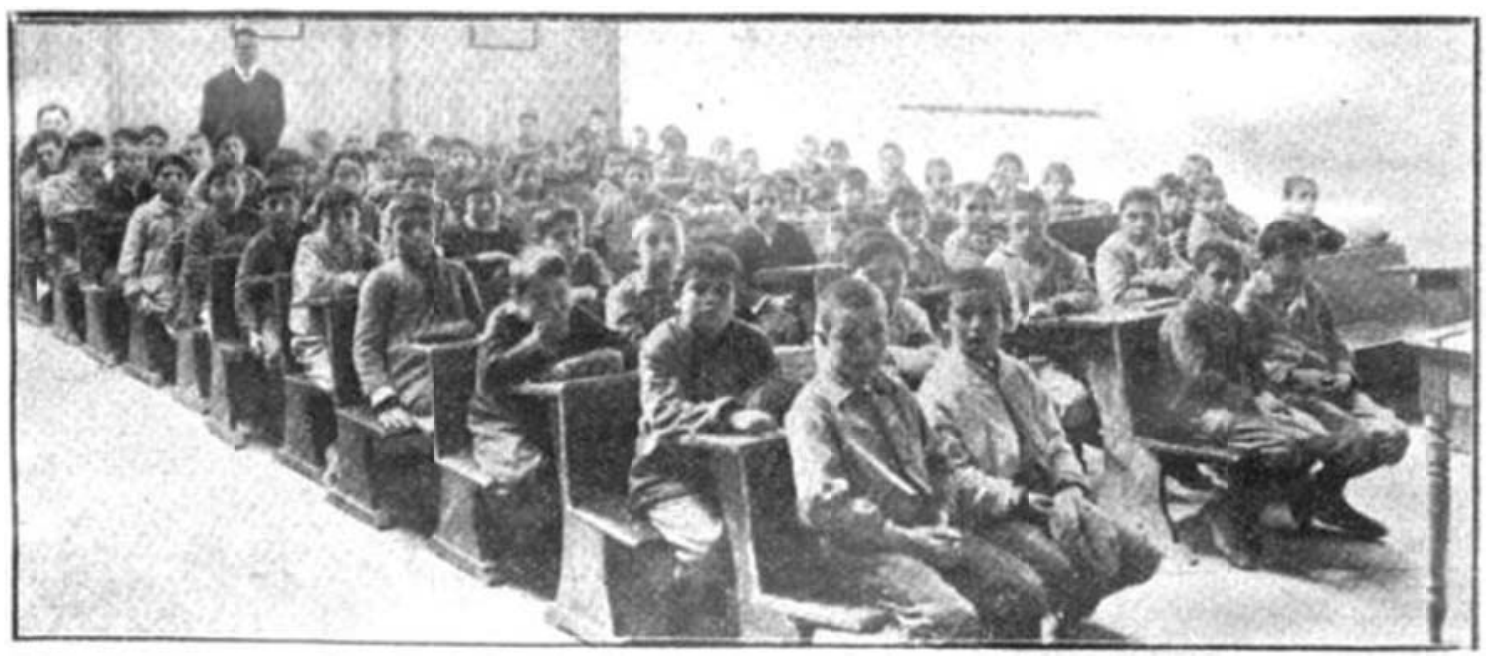

229. Antonio Vidal and Charles Robertson, “The 'Open-Air School’ in Scientific Pedagogy: Initiatives of the Argentine School System,” in Fourth International Congress on School Hygiene, vol. II, ed. Thomas A. Storey (Buffalo, New York, 1914), II:167.

230. Antonia Vidal and Charles Robertson, “The 'Open-Air School' in Scientific Pedagogy: Initiatives of the Argenine School System,” Session II - Open Air Schools, Fourth International Congress on School Hygiene (Buffalo, New York, 1913), 167.

231. ”Una de las aulas,” Foto de Caras y Caretas, “Los Chicos de la Quema,” 522. 
Figure 3.7: Children exercising in Parque de los Patricios ${ }^{232}$
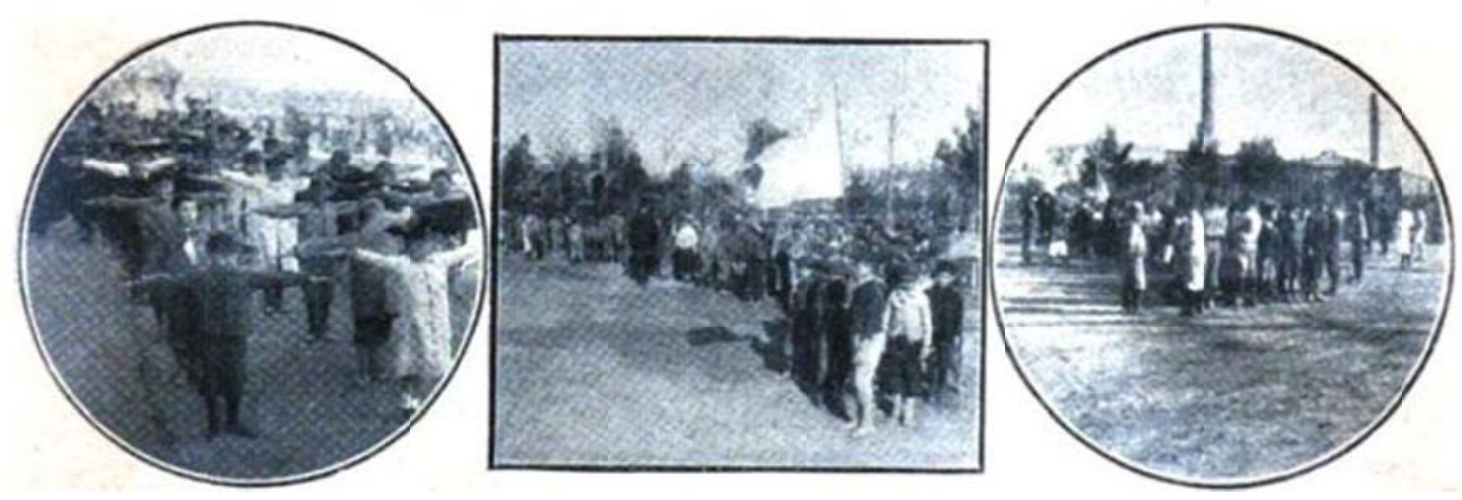

Dr. Antonia Vidal and Charles Robertson of Buenos Aires described the physical and mental improvements open-air schools brought the children of the city, however they point out that the home disrupts this progress. "The process of improvement is interrupted by the home, where unhealthy physical conditions are prevailing, and at times the moral influence has an adverse effect."233 Children who were behind in school or acted out with bad behavior would receive a medical examination to determine their mental and physical deficiencies. Those children found to be deficient in some way were sent to sessions of three months at a time in the open-air school for rehabilitation until they were deemed normal. ${ }^{234}$ Dr. Vidal described the open-air school as "prophylactic prevention,” as the deficiencies in the child's physical and mental health were treated as a disease. He breaks down the population of children in Buenos Aires into five categories

232. ”Ejercicios gimnasticos y militares, en el Parque de los Patricios,” Foto de Caras y Caretas, "Los Chicos de la Quema,” 523.

233. Antonio Vidal and Charles Robertson, “The ‘Open-Air School’,” 168.

234. Mildred Champagne, “The Children of Parque Lezama,” National Magazine an Illustrated American Monthly XLIII (October 1915 to March 1916 1915-16): 1033-34. 
between healthy "normal” children and "feeble" or "sick" children. ${ }^{235}$ Of the school population of 200,000 students, he argues 25,000 should be in a rehabilitative open-air school. ${ }^{236}$ In other words, he viewed that a quarter of the children in Buenos Aires were deficient, and abnormal, with most of these deficiencies coming from the conditions of the home and the neglect of the parents.

Every day, a physician examined the children of Lezama (See Figure 3.8). “A map is drawn of the child's exact mental, moral and physical status, its character, degree of aptitude and intelligence, and from day to day the map is changed.”237 Normal childhood was mapped with clear boundaries and abnormal children were reformed until they matched those boundaries. A Boston educator, Mildred Champagne, visited the school and reported on the daily activities of the school in 1916. Children arrived to the school at 7:30 am and were first bathed. A focus on hygiene and physical health filled most of the day, and after baths, the children are fed breakfast then sunbathe for half an hour. Champagne noted that "this is their chance of a lifetime," to bathe and receive proper nourishment. ${ }^{238}$ The day is broken into short lessons, conducted under the shade of trees, and periods of recreation and rest. Similarly to the school in Parque de los Patricios, at the end of the day, the girls learn to sew and the boys do manual labor before returning home at $6 \mathrm{pm}^{239}$ Champagne notes that "as soon as the child is pronounced

235. Antonio Vidal and Charles Robertson, “The ‘Open-Air School’,” 169.

236. Antonio Vidal and Charles Robertson, “The ‘Open-Air School’,” 170.

237. Champagne, “The Children of Parque Lezama,” 1035.

238. Champagne, “The Children of Parque Lezama,” 1035.

239. Champagne, “The Children of Parque Lezama,” 1035-37. 
normal it is obliged to leave the school to make way for another child who is eagerly waiting to enter."240

Figure 3.8: Daily Medical Examination at Lezama, $1915^{241}$

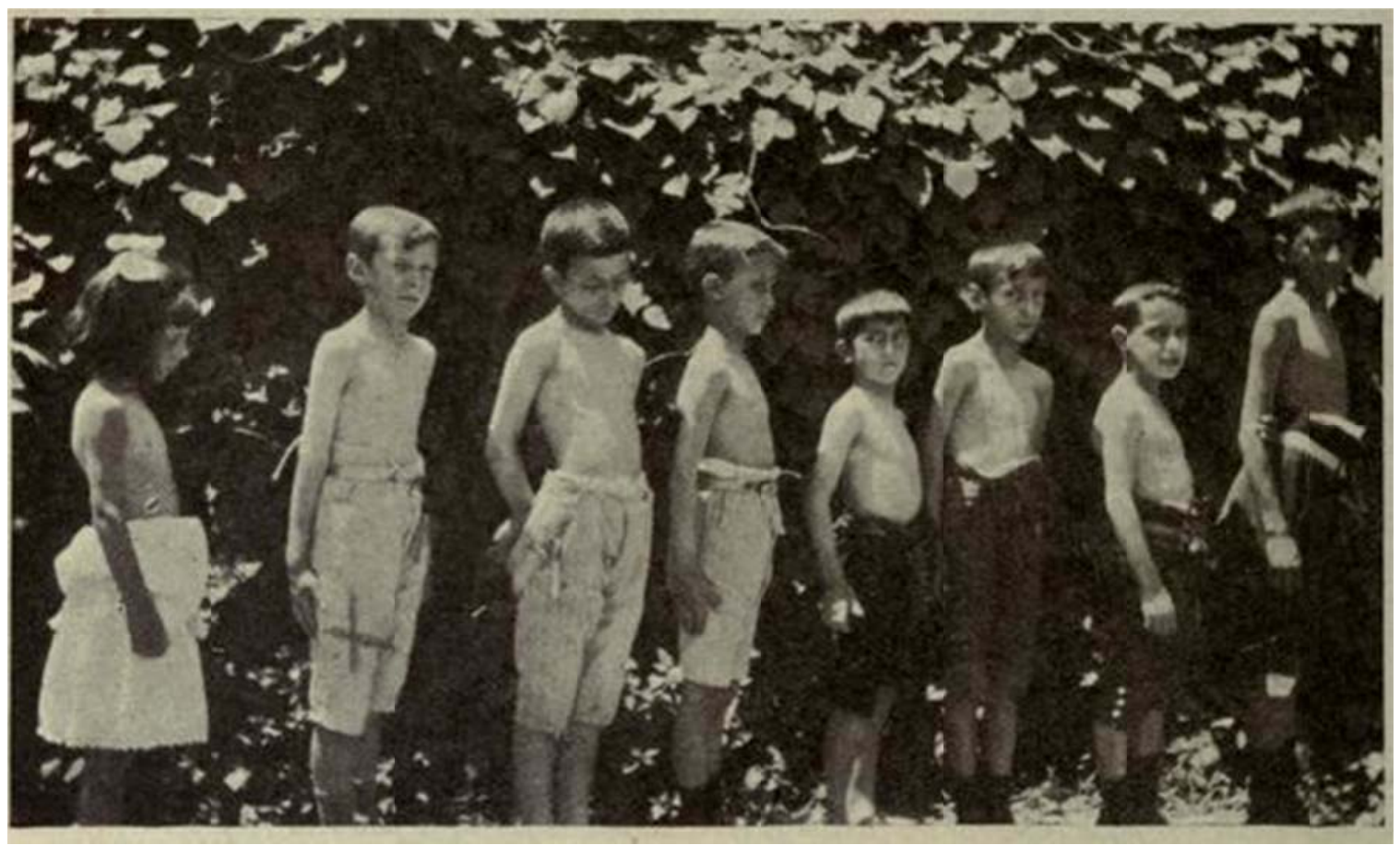

These examples in the southern barrios of Buenos Aires reflect the state's policy of socio-spatial exclusion through the public park system. By creating parks for the poor, similar in likeness, but certainly not equal to the parks for the elite, these spaces created new boundaries - both real and imagined - for the children in the southern districts. While parks were praised for their hygienic, healthful contributions to urban childhood, they also provided a place for government authorities to control and define childhood, a

240. Champagne, “The Children of Parque Lezama,” 1037.

241. "Up for Daily Medical Examination,” Photo printed in Champagne, “The Children of Parque Lezama,” 1034. 
space traditionally relegated to the authority of the home. In an effort to engineer a future adult Argentine population, supervised programs of recreation were implemented and aimed at immoral, unhealthy or weak children. Those who did not meet the expectations of the elite were deemed abnormal and in need of rehabilitation. These practices were both sanitizing - civilizing - of the children and their spaces. Through the examination of the evolving socio-spatial landscape of the city and the era of scientific child-saving recreational programs pioneered by the state, the production of a discourse on a modern "normal" - childhood, and its other, is better understood. 


\section{CHAPTER IV}

\section{INSIDE THE SANATORIO Y SOLARIUM MARÍTIMO}

In late nineteenth century Argentina, both public and private institutions

increasingly monitored and advocated for the health of children. This was most visible in the development of centers for children's health such as pediatric hospitals and other asylums for sick children. With tuberculosis on the rise, doctors and hygienists viewed a lack of proper hygiene in the urban environment and the general condition of the poor as the main cause for the spread of the disease. In adults, pulmonary tuberculosis, or tuberculosis of the lungs, was most common. This was often referred to as consumptive tuberculosis. Children, however, were more susceptible to extrapulmonary tuberculosis. This form of the disease presented itself outside of the lungs, in the bones or joints, for which the remedy at the time consisted of extensive surgery. For this reason, extrapulmonary tuberculosis was often referred to as surgical tuberculosis until the midtwentieth century when concerns arose over the debilitating effect these surgeries had on children’s long-term development.

In 1892, Dr. Emilio R. Coni, a prominent Argentine physician, applauded the natural environment as curative and encouraged sending sick and weak - also regarded as “pretubercular” - children away from the city to sanatoriums and colonias de vacaciones, or holiday camps, for rehabilitation. ${ }^{242}$ Inspired by German sanatoria constructed outside of the urban environment, public and private institutions in Argentina created sanatoriums and colonias de vacaciones, new landscapes away from the city, either in the

242. Armus explains how children of the poor were considered at risk of tuberculosis and were often categorized as “weak” or pre-tubercular. Diego Armus, The Ailing City: Health, Tuberculosis, and Culture in Buenos Aires, 1870-1950 (Durham and London: Duke University Press, 2011). 
countryside, the mountains or seaside. ${ }^{243}$ These institutions were intended to heal, revitalize and rehabilitate sick or weak children through a regimen of nutrition and outdoor activity in "natural" environments. In the 1904 Argentine guide to medicine and hygiene, doctors agreed the colonias would be an important compliment to playgrounds, as they took children away from the confined spaces of city life and "restored their weak bodies." ${ }^{244}$ This chapter explores the landscape of the Asilo Marítimo in Mar del Plata, a unique combination of sanatorium and colonia de vacaciones for children, and through the examination of institutional records, examines the climactic treatment of its children.

Hygienists and reformers informed the architecture of primary schools in Buenos Aires, and argued that the first line of defense against children's disease was the establishment of playgrounds for outdoor recreation. They also recommended improvements to the ventilation of school buildings and the regular disinfection of classrooms. ${ }^{245}$ Hygienists promoted a campaign of fresh air and sunlight, not only as a cure for a variety of children's ailments, but also as a preventative to tuberculosis specifically. They pointed to the lack of space in the overcrowded city as the biggest obstacle to the prevention of the spread of disease. The association of tuberculosis with overcrowded schools and overcrowded homes, contributed to a view that the urban poor was responsible for the spread of disease. Identifying and separating sick children served as a tool for urban planners to isolate the spread of disease, and open-air schools for weak

243. For a review of the movement in Germany see: Eva Eylers, "Planning the Nation: The Sanatorium Movement in Germany," The Journal of Architecture 19, no. 5 (2014): 667-92 Eylers refers to the sanatorium as the 'other' to the city, revealing how sites outside of the city became beacons of health.

244. Emilio R. Coni, Presidente de la Comisión organizadora, Argentina Médica, Guía Médica é Higiénica (Buenos Aires: Imprenta y Casa Editora de Coni Hermanos, 1904), 285.

245. Coni, Argentina Médica, 283-84, 287. 
children served as an example of this response. However, professionals increasingly viewed the city as lacking the space or environment for the healthful recovery of both sick adults and children. They imagined sanatoriums and colonias de vacaciones as antitheses to the city, as centers of health and recovery, rather than contagious breeding grounds within the urban environment.. ${ }^{246}$

Historians of these institutional phenomena in Argentina, and elsewhere, often examine how the development of these spaces was a response to a social problem. The state, coupled with philanthropic organizations, used a culture of hygiene to improve the social condition of the urban environment, as well as monitor and discipline the poor. ${ }^{247}$ Historian Adriana Alvarez, in her work on experiences at the Asilo Marítimo, attempts to provide a more complex view of the seemingly "unidirectional” power dynamic and relationship often depicted between health institutions and the child. ${ }^{248}$ In contrast to historiography typically positing institutionalization as a top/down model toward the separation of the child from the home, Alvarez provides insight into the parental rights of some of the parents whose children attended the Asilo. ${ }^{249}$ Alvarez also provides a look into the "experience" of the children, though the work weighs heavily on the children's

246. Vera Blinn Reber, “The Sanatorium Age Pennsylvania and Arentina, 1900-1945,” Pennsylvania History: A Journal of Mid-Atlantic Studies 73, no. 4 (2006): 414.

247. Eduardo O. Ciafardo, Los Niños en la Ciudad de Buenos Aires (1890-1910) (Centro Editor de América Latina, 1992); Vera Blinn Reber, "Poor, Ill, and Sometimes Abandoned: Tubercular Children in Buenos Aires, 1880-1920,” Journal of Family History 27, no. 2 (April 2002): 128-49; Armus, The Ailing City.

248. Adriana Álvarez, “La Experiencia de Ser un ‘niño Débil y Enfermo’ Lejos de Su Hogar: El Caso del Asilo Marítimo, Mar del Plata (1893-1920),” História, Ciências, Saúde-Manguinhos 17, no. 1 (JanuaryMarch 2010): 13-31.

249. Álvarez, “La Experiencia de Ser un ‘niño Débil y Enfermo’,” 25. 
lives before and after their treatment. ${ }^{250}$ In another similar article, co-written by Alvarez and Daniel Reynoso, the authors link emerging concepts of play in the 1920s to the rehabilitative practices of the Asilo. ${ }^{251}$ This chapter builds on this work and adds to a greater understanding of the climatic treatment of the children at the Asilo in the first decades of the twentieth century.

The ladies of the Catholic philanthropic institution, the Sociedad de Beneficencia, or Society of Beneficence of the Capital, constructed and ran the Asilo Marítimo, also referred to as the Sanatorio Marítimo and Solarium de Mar del Plata. ${ }^{252}$ While the Sociedad provided assistance to women and children throughout the nineteenth century in the city of Buenos Aires, the construction of the Asilo was part of a period of expansion for the Sociedad outside of the Capital. They received public funds to open a number of asylums away from the city to rehabilitate both the behaviors and health of boys and girls. ${ }^{253}$ This expansion rested largely on the thinking of the medical community that children could be transformed - physically and spiritually - by fresh air, and that the polluted city could not provide them with this environment.

250. It is important to note the difficulty in uncovering the children's voice or experiences within the institution’s archival documentation. Álvarez, “La Experiencia de Ser un ‘niño Débil y Enfermo’,” 22-26.

251. Adriana Álvarez and Daniel Reynoso, "Entre el Abandono y la Debilidad. El Cuidado de la Salud en la Primera Infancia, 1920-1930,” in Infancias: Políticas y Saberes en la Argentina y Brasil: Siglos XIX y XX, ed. Isabella Cosse and [et. al.] (Buenos Aires: Teseo, 2011), 123-48.

252. In its early years the Sanatorio was known as the Hospital y Asilo Marítimo. I refer to the institution as the 'Asilo Marítimo,' or 'Asilo' for short, and specify at times between the Sanatorio and Solarium.

253. Guy provides insight into the Society's expansion after 1900 and how the ladies operated in a political world dominated by men. For more see: Donna J. Guy, Women Build the Welfare State: Performing Charity and Creating Rights in Argentina, 1880-1955 (Durham and London: Duke University Press, 2009), 45-48. 
The directors of two institutions run by the Sociedad, the Casa de Expósitos and the Hospital de Niños in Buenos Aires, were doctors Juan M. Bosch and Antonio AR raga, and they reported in 1893 the needs for a sanatorium for their sick and weak children. The Sanatorium, established in 1893, and later the Solarium established in 1918, provided a unique mix of hospital and holiday camp aimed to "assist weak and sick children from the Sociedad.”254 Well-kept institutional records provide us a glimpse into the daily activities and climatic treatment of the children who stayed at the Asilo Marítimo. First, I examine the efforts to create a healing landscape at the Asilo and explore some of the challenges presented by caretakers and doctors during the process. Second, I outline the routines and expectations of children undergoing climactic treatment, providing a window to view their daily lives and activities within the institution.

\section{The Landscape of the Climate Cure}

In an 1893 letter to the President of the Sociedad de Beneficencia, a committee in Mar del Plata approved of the site that would become the Asilo Marítimo. Once a German hotel, the building had thirteen rooms, including a salon and kitchen. It was situated about 500 meters from the beach and just south of a brand new resort in Mar del Plata. The committee agreed it provided the perfect base to "provide healthy accommodations and sea air to a number of children.”255 They described the benefits of

254. Sociedad de Beneficencia de la Capital, "Reglamaneto del Hospital y Asilo Marítimo,” AGN (Buenos Aires, 1909), 5.

255. Archivo General de la Nación, Buenos Aires (AGN). Fondos de Sociedad de Beneficencia (SB), Sanatorio

Marítimo, Legajo 103, January 31, 1893. 
this restorative environment, with the hotel's desirable location near the beach, settled on a large green surface, with plenty of room to plant a garden for herbal remedies. The location of the beach was also ideal, with plenty of room for children to spend the day in the sand, mostly protected from winds. The hotel already had large windows facing the sea, providing a "pure atmosphere,” and access to lots of sunlight and the fresh sea air. ${ }^{256}$ The coastal city of Mar del Plata is located about 250 miles south of Buenos Aires, accessible by train since the 1880s. The Sociedad sought to bring the healthful beaches “designated a privilege of the rich,” to the sick and underprivileged children of Buenos Aires. $^{257}$

The Sanatorio Marítimo began operating in 1893 with forty beds for weak and tubercular children under 14 years old. Until 1900, it only ran during the summer months, but extensions were added to allow it to run all year. Under the direction of Dr. Héctor Jara, the establishment was divided between the Sanatorium, primarily for the treatment of non-pulmonary tuberculosis, and the Colonia de vacaciones, primarily for the strengthening of weak children to prevent tuberculosis. The institution grew quickly and by 1914, the Asilo could accommodate four times more children with 180 beds. $^{258}$ During the process of expansion, the Sociedad often consulted with doctors to provide a treatment experience informed by the latest science in the fight against tuberculosis. This was a common European practice. Architectural historian Margaret Campbell examines the sanatorium movement and its influence on modern architectural

256. AGN, SB, Sanatorio Marítimo, Legajo 103, January 31, 1893.

257. AGN, SB, Sanatorio Marítimo, Legajo 103, April, 8, 1901.

258. AGN, SB, Sanatorio Marítimo, Legajo 103, informe de las estadísticas, February 10, 1915. 
design in Europe, and reveals that the movement "involved the integration of form with social purpose.”259 Essentially, the designs of sanatoriums, especially for tuberculosis, were similar around the world because the accepted treatment involved specific features highlighting the healthful benefits provided by the landscape.

The medical community increasingly discussed the treatment of tuberculosis at scientific conferences around the globe in the early twentieth century, including treatment for extrapulmonary tuberculosis, which presented itself in the bones or other places outside of the lungs. To prevent and cure tuberculosis, doctors and hygienists agreed, "one must have healthful surroundings.,260 At the 1890 Berlin International Medical Congress, a German physician, Dr. Hermann Weber, introduced the "climactic treatment,” whereas patients with tuberculosis would undergo medically supervised treatment in specific climates, including the mountains, forests, and the sea. ${ }^{261}$ In 1882, Robert Koch discovered that tubercle bacilli caused the disease and was responsible for the spread of tuberculosis between individuals through the air. Another doctor in the Mediterranean argued that the cure included an abundance of exposure to the "sun, sea

259. Margaret Campbell, "What Tuberculosis Did for Modernism: The Infuence of a Curative Environment on Modernist Design and

Architecture,” Medical History 49, no. 4 (October 2005): 463.

260. William Dodge Frost and Michael Vincent O’Shea, The Great White Plague; Simple Lessons on Causes and Prevention, Intended Especially for Use in Schools (Madison: Democrat Printing Company, 1912), 39.

261. Hermann Weber M.D., "Remarks on Climate and Sea Voyages in the Treatment of Tuberculosis. Read Before the International Tuberculosis Congress in Berlin,” The British Medical Journal, 3 June 1899, 1321. 
and pure air."262 The science behind this climate cure was relatively simple; the sun killed tubercle bacilli and the salty sea disinfected the air. At the 1908 Washington International Congress on Tuberculosis, the message was similar, and physicians deemed the best treatments for extrapulmonary tuberculosis, aside from surgery, incorporated climatic seaside, outdoor treatments. The regimen doctors recommended patients follow included lots of rest, an abundance of exposure to the sun, breathing in fresh air and eating a nutritious diet. ${ }^{263}$ Sanatoria by the sea and in the mountains popped up throughout the Atlantic world as sites to isolate patients at risk for tuberculosis and also to cure tuberculosis within the healing landscapes.

In 1901 correspondence describing the Asilo, the Sociedad eloquently portrayed the power of the sea as a beacon of health. From the fresh salty air to the vibrations of the waves, each element revived the body and "infused new life" into the children. ${ }^{264}$ They viewed the salty seawater as a disinfectant, both for the body and the air. The waves massaged the broken body, toning the muscles and improving blood circulation. They contrasted this seaside environment to the "miserable" condition of the Hospital de Niños in the city, with its "stale atmosphere" and "lamentable hygienic conditions." 265 The cure to the ailments caused by city life appeared in the pure air natural climate of the seaside town. By 1914, the Sociedad had constructed 5 different

262. Review of the Berlin Congress, Dr. E.M. Dupaquier, “Department of General Medicine,” New Orleans Medical and Surgical Journal LII, no. 3 (September 1899): 175.

263. De Forest Willard M.D., "Open-Air Treatment of Surgical Tuberculosis," in Sixth International Congress on Tuberculosis, Washington September 28 to October 5, vol. 2 (Philadelphia: William F. Fell Company, 1908), 2:264-65.

264. AGN, SB, Sanatorio Marítimo, Legajo 103, April 8, 1901.

265. AGN, SB, Sanatorio Marítimo, Legajo 103, April 8, 1901. 
pavilions for the sick children, 24 salons, and 18 rooms for personnel. With 180 beds for the children and 60 for personnel, the institution had grown tremendously. ${ }^{266}$

While health professionals viewed the location of the Asilo as an ideal space for the prevention and healthful recovery of tuberculosis, staff experienced some difficulties in applying the treatment. For weak children entering the Asilo to strengthen their constitution in the prevention of tuberculosis, accessing the beach for bathing in the sea did not present much of a problem. However, most of the children with extrapulmonary tuberculosis received surgery upon their arrival and were largely immobile. Moving these children through the sands of the beach proved quite difficult. In monthly reports to the Sociedad, requests were made for better access to the beach, especially for these children to utilize the healing power of the sea. ${ }^{267}$ Physicians at the Asilo thought sea bathing, also known as thalassotherapy when used as a medical treatment, complimented healing. In part, this was due to the disinfectant properties of chlorides in the water, but also because they believed the pressure of the waves crashing on the body invigorated and massaged the blood vessels, and toned the weakened muscles of the children's healing bodies. ${ }^{268}$

In 1918, the Sociedad inaugurated the Solarium, constructed to expand the capacity of the Asilo and to improve the heliotherapy treatments (See Figure 4.1). Located just 50 meters from the beach, it also provided easier access to the sea. At the

266. AGN, SB, Sanatorio Marítimo, Legajo 103, informe de las estadísticas, February 10, 1915.

267. AGN, SB, Sanatorio Marítimo, Legajo 103, April 18, 1901. See also, J.H. Jara, "Memoria del Hospital y Asilo Marítimo (Mar del Plata),” in Memoria del Año 1906, Sociedad de Beneficencia de la Capital (Buenos Aires, 1906), 323.

268. Jara, “Memoria del Hospital y Asilo Marítimo,” 324-25. 
inauguration of the Solarium, the President of the Sociedad, Elena Napp de Green, described the suffering of children with extrapulmonary tuberculosis and provided the Solarium as the best cure, "you can only effectively fight it in an environment like this," referencing the curative properties of the sun and the sea. ${ }^{269}$ The Solarium featured two dormitories separating the girls from boys with a large patio in between. Later that year, the Sociedad also began construction on a system to pull the seawater into the Solarium. The new system, finished in 1924, provided easier access to the healthful properties of the seawater and controlled the temperature of the water, making it useful all year round. ${ }^{270}$

In 1927, the Sociedad expanded the design of the Solarium under the advisement of the medical director, Dr. Rodriguez Egaña, to provide a specialized space for the modern treatments of extrapulmonary tuberculosis. Directly behind the dormitories were bathrooms and rooms for sterilization and radiography. Since this type of tuberculosis often affected the bones in children, in the center of the Solarium were installed rooms for surgery and the application of plaster casts, with infirmaries located on both sides. ${ }^{271}$ The dormitories faced the sea with large windows that could be opened to let the sea air inside day or night. The windows curved upwards toward the center of the ceiling and the walls were painted white to allow the maximum amount of sunlight to enter and reflect within the dormitory throughout the day (See Figure 4.2). Another patio ran

269. AGN, SB, Solarium de Mar del Plata, Legajo 95, Expediente 196, March 24, 1918.

270. AGN, SB, Solarium de Mar del Plata, Legajo 95, “Captacion agua de mar para Solarium, 1918/1924,” Expediente 5160.

271. AGN, SB, Solarium Mar del Plata, Legajo 96, Planos de Amplicacion y correspondencia, November 16, 1926. 
outside the long line of the dormitories to allow the nurses to bring the beds outside, so the children could lie in their beds outside, again for maximum sun exposure.

Figure 4.1: Solarium de Mar del Plata, $1926^{272}$

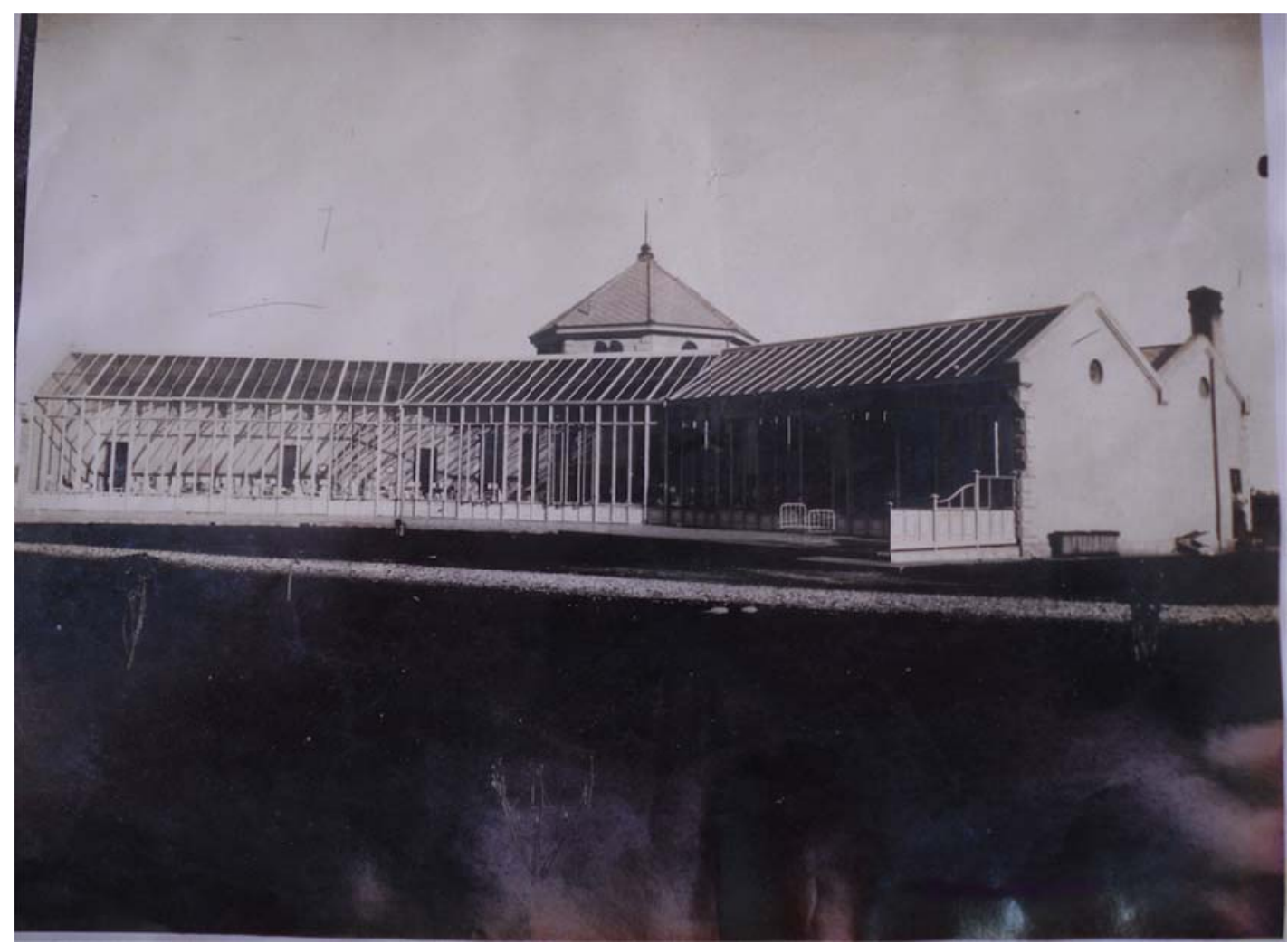

The new space sometimes presented cultural challenges. Concerns were raised several times over girls sunbathing in the Solarium, often with little coverage of their bodies, so close to the beach and potentially in public view. In an effort to maintain privacy, the Sociedad built a wall to protect the sunbathing children from being seen inside the solarium. ${ }^{273}$ By the 1930s, tourists increasingly visited Mar del Plata, and

272. AGN, SB, Solarium de Mar del Plata, Legajo 96, Foto de los dormitorios en el Solarium, 1926.

273. AGN, SB, Solarium de Mar del Plata, Legajo 95, April 18, 1918. 
concerns over the privacy and visibility of children at the Asilo grew. In 1935, the Sociedad acquired a small beach south of an existing seawall that would provide additional privacy to the children bathing in the sea. The issue expressed was that it was difficult for the girls to bath in the sea without "the intrusion of strangers."274 The Sociedad served to protect the modesty and morality of the children, however as Mar del Plata grew in popularity amongst the privileged classes, the increasing demand for privacy also reveals the desire to keep the Asilo separate from the rapidly expanding resort town.

Figure 4.2: Girls resting inside the Solarium de Mar del Plata ${ }^{275}$

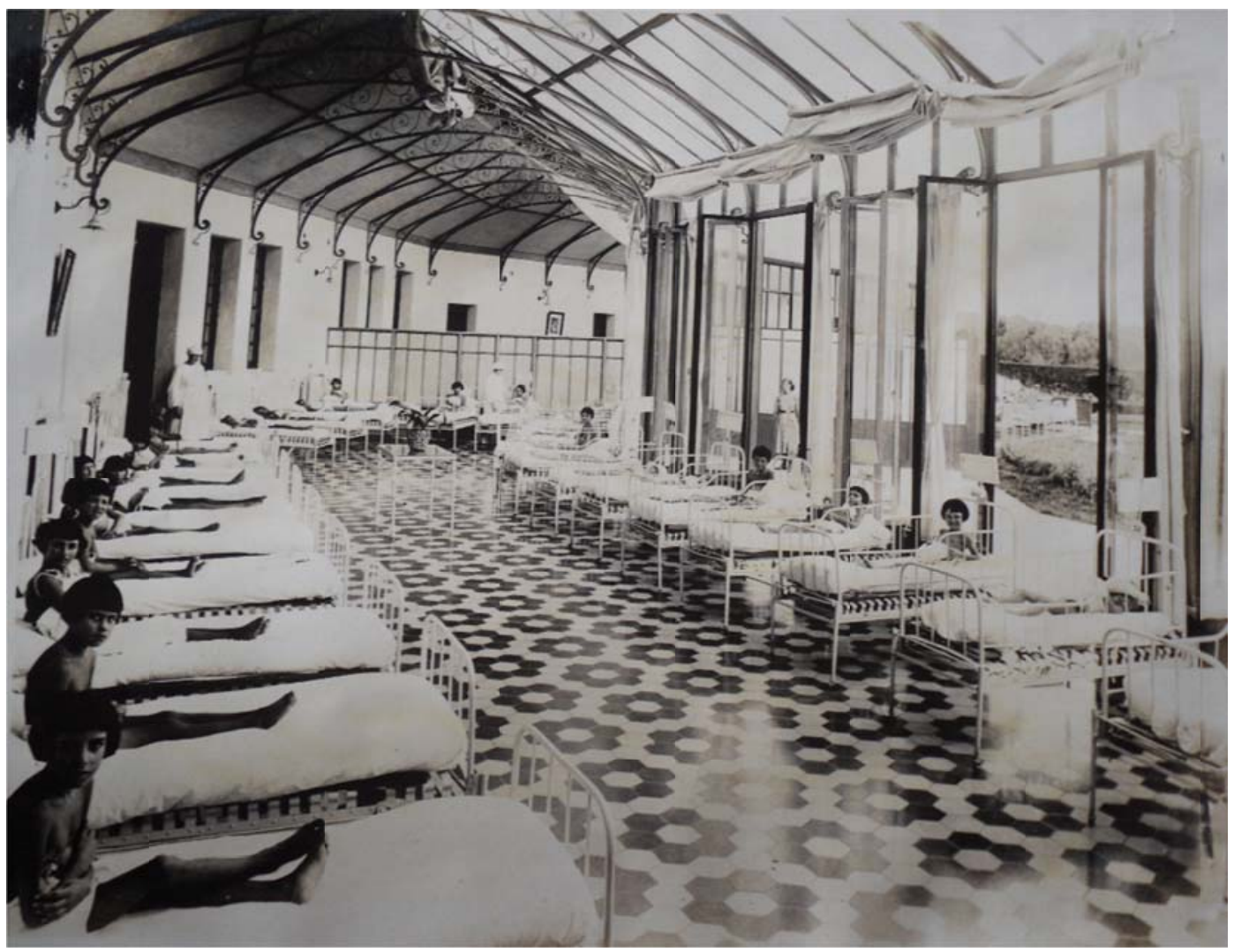

274. AGN, SB, Solarium de Mar del Plata, Legajo 97, December 28, 1935.

275. AGN, SB, Solarium de Mar del Plata, Legajo 96, Foto de la Sala de Niñas en el Solarium, 1926. 
The women of the Sociedad consulted doctors regularly when recommending changes or new constructions to the Asilo, to implement technical innovations and "take advantage of the latest achievements of science. ${ }^{\text {,276 }}$ However, at times they did not always agree. In the early twentieth century, physicians, politicians and philanthropists typically agreed that tuberculosis was a social disease, contracted and spread largely by the poor. Dr. Salvatore A. Pratto poignantly argued, "the fight against tuberculosis is not merely technical but it is a medical-social fight.”277 Pratto reemphasized the point that the tubercle bacillus was not the most destructive element, but instead it was the unhealthy environment - lack of fresh air and light - and the "ignorant” working classes. ${ }^{278}$ Increasingly by the 1920 s, there was a divide, especially between Catholic institutions like the Sociedad, who still viewed tuberculosis largely as a social problem, and doctors who focused more exclusively on the medical treatment of tuberculosis. These divisions sometimes challenged the relationship between the Sociedad and the professionals they consulted.

In 1923, the medical director of the Asilo, Dr. Alberto Rodriguez Egaña raised the issue with the Colonia de Vacaciones, asking to discontinue the pavilion of the Asilo marked for "weak children," and use that space for patients with extrapulmonary tuberculosis. ${ }^{279}$ His proposed project would fully separate girls and boys, appropriate the

276. AGN, SB, Solarium de Mar del plata, Legajo 95, Expiente 1901, año 1918.

277. Salvador A. Pratto, “Address of Dr. Salvador A. Pratto, Opening Address,” in The American International Congress on Tuberculosis, J. Mount Bleyer (St. Loius: Medico-Legal Journal, 1904), 173.

278. Pratto, “Opening Address,” 173-74.

279. AGN, SB, Sanatorio Marítimo, Legajo 98, February 14, 1923. 
playground for the children of the Colonia and turn it into an isolation ward, and also increase the space for girls to sunbathe in the patio. The doctor provided a list of reasons explaining why this was the best course of action for the Asilo. First, he argued that the Asilo was breaking the first rule in the treatment of tuberculosis by not completely isolating its pulmonary patients. Extrapulmonary tuberculosis was not considered a contagious threat, however those children were still susceptible to contracting pulmonary tuberculosis. By not isolating them from the Colonia, they were potentially exposed to pulmonary tuberculosis. Since those children were already debilitated and their immune systems weakened, he argued, they were more likely to contract ailments from the children of the Colonia. Second, he argued that the maritime climate was not essential, and at times actually harmful, to the rehabilitation of pretubercular children - as was reiterated at conferences on tuberculosis and hygiene - so the Colonias better served those children at another site, either closer to or within urban population centers. Finally, since the Asilo was the only institution in the country dedicated to the fight against extrapulmonary tuberculosis in children, the doctor posited the space would be best used exclusively for those patients.

The Sociedad did not agree. They reached out for a second opinion from Dr. Don Adolfo Oyenard on the elimination of the Colonia, as they often did, to support their position to instead continue the program. Dr. Oyenard suggested that while it was important to isolate the units for weak children from the extrapulmonary patients, they should not eliminate the Colonia de Vacaciones program completely, since it served a great purpose in the social fight against tuberculosis. He suggested instead that they build a new pavilion on a block of land near the Sanatorium to serve as an isolation ward. 
If that was not possible, he suggested reducing the number of children who attended the Colonia to make room for further isolation. ${ }^{280}$ The Sociedad did not want to eliminate the Colonia because they deemed it entirely necessary to improve the social condition of abandoned children. ${ }^{281}$ Since there were not enough funds at that time to build a new pavilion, they reduced the number of beds for weak children from 160 to only 60 beds, 30 for boys and 30 for girls, and rearranged the existing space to isolate those children from the tuberculosis patients. ${ }^{282}$ Physicians contested this arrangement several times over the years, and additional pavilions were added to accommodate the physicians’ requests. ${ }^{283}$ Still, even in the 1940s, the Colonia de Vacaciones program remained relatively small and only accommodated around 50 children. ${ }^{284}$

The Sociedad and the medical staff negotiated to create an ideal environment for the treatment of children at the Asilo Marítimo. From the time it was founded in 1893 till the 1930s, the Sociedad, with funding from the state, embarked on vast expansions to accommodate larger quantities of children and more specialized treatment options. This process reveals not only the prevailing medical need for the treatment in extrapulmonary tuberculosis in children, but also provides an example of how changing definitions of the needs of childhood shaped both private and public institutions. Similarly to how open-air schools aided in the articulation of the "normal" child, juxtaposed to the "abnormal," the

280. AGN, SB, Sanatorio Marítimo, Legajo 98, July 3, 1923.

281. AGN, SB, Sanatorio Marítimo, Legajo 98, Acta de Consejo, August 8, 1923.

282. AGN, SB, Sanatorio Marítimo, Legajo 98, September 4, 1923.

283. AGN, SB, Sanatorio Marítimo, Legajo 99, Acto de Consejo, December 7, 1928.

284. AGN, SB, Sanatorio Marítimo, May 30, 1944. 
Asilo’s Colonia de Vacaciones provided a space to articulate the "healthy" child, juxtaposed to the "unhealthy" child. The experiences of children within the institution reveal further tensions between the treatment of foundlings from the Casa de Expósitos and children referred to the Asilo by hospital physicians.

\section{Childhood in the Asilo}

Most of the children that entered the Asilo for treatment came from one of two institutions run by the Sociedad de Beneficencia, the Casa de Niños Expósitos (foundling home) and the Hospital de Niños (children's hospital). These institutions both aimed to provide assistance to the poor and abandoned children of Buenos Aires. For most of the children at these institutions, their conditions were generally poor and their chances of contracting a disease was relatively high. Often, when parents could no longer care for their sick children, they would "abandon" them into the care of the Sociedad. Historians of childhood in Latin America, such as Nara Milanich and Ann Blum, revealed how families practiced child circulation throughout the colonial period and well into the twentieth century. Parents often placed children in a network of care, including extended family or neighbors, but also within state and private institutions, when they could not afford to properly provide for their children. ${ }^{285}$ In the case of the Casa de Expósitos, sick children were often left to the care of the institution in hopes they would receive medical treatment. It was not uncommon for parents to write the Sociedad requesting information

285. Nara Milanich, "The Casa de Huérfanos and Child Circulation in Late-Nineteenth-Century Chile," Journal of Social History 38, no. 2 (2004): 311-40; Ann S. Blum, "Public Welfare and Child Circulation, Mexico City, 1877-1925,” Journal of Family History 23, no. 3 (1998): 240-71. 
and sometimes asked to be reunited with their children. Still, between 1852 and 1912, half of the children that entered the Casa de Expósitos died in the institution. ${ }^{286}$

Historian, Vera B. Reber noted that one reason the death rate was so high at the Casa de Expósitos, was because "by the early twentieth century, 80 percent of the children in the Casa de Expósitos had been abandoned by working-class parents largely because they could not afford to take care of them." ${ }^{\text {287 }}$ When children became sick, especially in households with multiple children, parents left their sick children to the care of private and public institutions. More than half of the children at the Casa de Expósitos were considered pretubercular, meaning they were considered susceptible to tuberculosis due to their weakened condition. The Hospital de Niños provided free services to poor and working class families, and occasionally children were abandoned there as well. The hospital was not set up to take in tuberculosis patients, so they tried to send them to the Asilo Marítimo or another tuberculosis hospital. Since beds were scarce for tuberculosis, this was not always possible. Other requests for admittance came from physicians of parents who had difficulty paying for the surgical care of their children. For example, a mother cared for a six-year-old girl with Pott's disease, or tuberculosis of the spine, along with eight other children. She could not pay for the care her sick daughter required, so requested she be admitted to the Asilo. ${ }^{288}$ Another request came for a three-year-old girl that was abandoned by her mother, and whose father lacked the resources to pay for her

286. Reber, “Poor, Ill, and Sometimes Abandoned,” 131.

287. Reber, “Poor, Ill, and Sometimes Abandoned,” 132.

288. AGN, SB, Sanatorio Marítimo, Legajo 103, November 29, 1913. 
care. $^{289}$ Another child had been in the hospital for a year, and it was requested that she enter the Asilo because her mother was of "bad morals" and "had no preoccupation for the health of her daughter."290 Most of the children that entered the Asilo, then, were either abandoned or came from poor families.

Children travelled by train from Buenos Aires to Mar del Plata. The British owned railway company, Ferrocarril del Sud, provided free train tickets and meals for both the children and employees of the Asilo who accompanied them on their travels. ${ }^{291}$ The journey by train began at the Plaza Constitución in Buenos Aires and it took several hours to reach the 250 miles to their destination. Typically, groups of children, anywhere between 50 and 100 at a time, travelled under the supervision of only a handful of Asilo employees. ${ }^{292}$ Once the children arrived, the children received an examination of their condition, and their weights were recorded. While the children's individual medical needs varied, they all underwent a similar rigorous hygienic routine, which included rest, many hours in the sun and sea, and a nutritious diet. Many children, especially those with extrapulmonary tuberculosis, also underwent numerous surgeries.

Everyday, the children followed a similar routine. ${ }^{293}$ They washed themselves and brushed their teeth when they woke up in the morning and before they went to bed in

289. AGN, SB, Sanatorio Marítimo, Legajo 103, June 9, 1900.

290. AGN, SB, Sanatorio Marítimo, Legajo 102, March 12, 1947.

291. AGN, SB, Sanatorio Marítimo, Legajo 103, April 29, 1893 and December 28, 1893.

292. AGN, SB, Sanatorio Marítimo, Legajo 103, informes mensuales 1901-1916.

293. For a more detailed description of the schedule of daily activities at the Sanatorio from Jose M. Jorge’s 1921 article in Semana Medica, "Sanatorio marítimo y solarium de Mar del Plata," see: Reber, "Poor, Ill, and Sometimes Abandoned,” 138-39. 
the evening. They received three meals a day, and a snack in the afternoon. Their activities kept them outside most of the day, weather permitting, so that they could take in the sun and breathe the fresh ocean air. Breathing exercises were encouraged throughout the day. Children spent several hours on the beach or sunbathing in the patio. This was done in both the morning and evening hours. If healthy enough, they would also take baths in the sea and play in the sand. Children spent an average of 5-7 hours a day sunbathing depending on the time of year. ${ }^{294}$ In one summer month, the children even spent an average of 9 hours a day in the sun. ${ }^{295}$ Girls and boys typically alternated days for bathing in the ocean, so on average each child bathed in the sea around 15 times a month. ${ }^{296}$ Two additional hours were designated for recreation, and the children typically played in the patio. The activities during this recreation time varied and were dependent on each child's condition, since the children were not supposed to over exert themselves. Unlike other colonias de vacaciones or open-air schools, the Asilo did not establish a rigorous pedagogic routine, but instead focused exclusively on the rehabilitation of the child's physical and spiritual health. ${ }^{297}$ Children received some religious instruction. In 1935, the Chaplain, concerned that the children’s "spiritual needs” were not being met, requested additional classes for religious instruction. He

294. AGN, SB, Sanatorio Marítimo, Legajo 99, informes mensuales January - December 1927.

295. AGN, SB, Sanatorio Marítimo, Legajo 99, informe mensual January 9, 1928.

296. AGN, SB, Sanatorio Marítimo, Legajo 99, informes mensuales 1927.

297. AGN, SB, Sanatorio Marítimo, Legajo 103, informe de las estadísticas, February 10, 1915. 
began to hold weekly "moral conferences" with the nurses and Sisters of the Sociedad, as well as religious classes twice a week with the children. ${ }^{298}$

The nurses at the Asilo also encouraged strict daily hygienic practices, in hopes that the children would implement them into their daily lives after they left the Asilo. The care to these hygienic practices cannot be overstated. While the children brushed their teeth twice a day, they also took a sanitary bath on average every other day and were encouraged to wash their hands regularly. ${ }^{299}$ The building was disinfected often and children changed clothing and bedding several times a day. In one month, over 23,000 items of clothing were washed using nearly 500 pounds of soap. ${ }^{300}$ Hygienists viewed the Asilo as a place to improve the daily habits of the poor, not only to return them to good health, but to also instill hygienic social practices that would prevent the spread of disease into adulthood. Historian Adriana points out, ironically, while practices of prevention played a large role at the Asilo, and though hygienists blamed the families of the poor for the spread of tuberculosis, the children from the Casa de Expósitos likely contracted the disease from within the institution. ${ }^{301}$

In addition to the concerns over insufficient space to breathe fresh air and inadequate access to the outdoors in general, physicians were also concerned over the insufficient amount of healthy and safe food available to poor children. Healthcare

298. AGN, SB, Solarium de Mar del Plata, Legajo 97, April 2, 1935.

299. AGN, SB, Sanatorio Marítimo, Legajo 99, informes mensuales, January - December 1927.

300. AGN, SB, Sanatorio Marítimo, Legajo 99, informe mensuale, Feb 81927.

301. Adriana Álvarez, “La Experiencia de Ser un ‘niño Débil y Enfermo’ Lejos de Su Hogar: El Caso del Asilo Marítimo, Mar del Plata (1893-1920),” História, Ciências, Saúde-Manguinhos 17, no. 1 (JanuaryMarch 2010): 23. 
professionals in the late nineteenth century noted the inadequate nutrition of children of the poor and viewed this deficiency as one of the primary causes for contracting tuberculosis. In a tuberculosis prevention guide for schools, the author reiterated, "In order to keep well one must also have wholesome food, properly cooked, regularly eaten, and completely digested." ${ }^{\text {302 }}$ They regarded the weakened body of the child as less able to fight disease and thus more susceptible to tuberculosis. In the fight against tuberculosis, various public and private organizations made efforts to improve the nutrition of the poor. Hygienists also believed that children could get tuberculosis from milk by cows that were infected with bovine tuberculosis. They recommended to only buying milk known to be from tuberculosis free cows. ${ }^{303}$ The Patronato de la Infancia created a program, “copa de leche,” and set up milk dispensaries in Buenos Aires to provide the children of the poor with safe, sterilized, pasteurized milk. ${ }^{304}$ They also disseminated information through pamphlets and other propaganda to get the word out that a healthful diet assisted in the prevention of tuberculosis. At the sixth International Congress on Tuberculosis, physicians agreed, "the diet must be nutritious and easily assimilated, - milk, eggs, meat, bread; as much butter as can be afforded, fruits, fats” were all recommended for a healthy lifestyle in the fight against tuberculosis. ${ }^{305}$

Providing an abundance of adequate nutrition thus formed an important part of the daily treatments of the children at the Asilo. Children were weighed when they arrived at

302. Frost and O’Shea, The Great White Plague, 40.

303. Frost and O’Shea, The Great White Plague, 27.

304. Coni, Argentina Médica, 51.

305. Willard M.D., “Open-Air Treatment,” 265. 
the Asilo and again monthly, reporting any gains or losses. Many of the children prior to arriving to the Asilo were malnourished, underweight, and in generally poor condition, so it is not surprising that they generally gained weight during their stay. Children ate three meals a day, which typically included generous portions of soup with vegetables, bread, quality milk and meat. ${ }^{306}$ Children were encouraged to drink plenty of water to aid in the digestion of their meals. In 1901, one report indicated that the high cost of eggs prevented the Asilo from serving them for a while, though they served a high nutritional value to the patients. They suggested dedicating a free part of land to raising chickens and to producing their own quality eggs. The children typically received around 2400 calories a day, and sometimes more in the winter months. ${ }^{307}$ Reports showed on average children gained 1-2 kilos a month. ${ }^{308}$ Calories were increased if the children were not gaining weight, often by providing additional milk. In another monthly report, some weight loss was reported due to the "extreme heat" the children endured. ${ }^{309}$ Physicians paid close attention to the children's diet and how it corresponded to their health and weight gain or loss, and even conducted studies in the 1940s on the children with varied diets to see which foods promoted the most healing and weight gain. ${ }^{310}$

Part of the treatment regimen for the children at the Asilo included plenty of rest, but the truth is that many of the children were immobilized and in a lot pain.

306. AGN, SB, Sanatorio Marítimo, Legajo 103, April 15, 1901; see also sample weekly menu in Legajo 103, 1903.

307. Reber, “Poor, Ill, and Sometimes Abandoned,” 139.

308. AGN, SB, Sanatorio Marítimo, Legajo 103, August 12, 1900.

309. AGN, SB, Solarium Mar del Plata, Legajo XXX, Feb 4, 1925

310. AGN, SB, Solarium de Mar del Plata, Legajo 97, July 8, 1943. 
Extrapulmonary tuberculosis affected the bones, joints and organs outside the lungs, and until the 1940s, painful intensive surgeries were conducted on the children to remove the disease in the affected areas or organs. This left children in a lot of pain, as very little medicine was used for pain control, and with deformed or amputated limbs, serious scars, and often long term immobilizations of the legs, hips or spine. Doctors used plaster casts to immobilize the effected body part to avoid deformities since children's bones were soft and still developing. After surgery, the children laid in a bed connected to a frame that hung them attached to a weight and pulley system. The weights were gradually raised to strengthen the bones and muscles until the children could place use their own body weight (See Figure 4.3). Especially in cases of spinal tuberculosis, which were common in children at the Asilo, children wore a torso cast and could not sit up or stand until their bones healed. ${ }^{311}$ This process of recumbence, combined with heliotherapy, formed the bulk of treatment for children with extrapulmonary tuberculosis. The healing process took several months to several years depending on the case. Sometimes, children did not survive. ${ }^{312}$

The medical community viewed surgery as only a part of the healing process. Physicians carefully crafted heliotherapy into the daily plans at the Asilo, not only during designated times of rest in the sun, but also during times designated for recreation in the patio and bathing times in the sea. Every activity was geared towards spending as much time as possible in the sun. Additionally the medical staff monitored the children's time

311. Lloyd T. Brown M.D., "Tuberculosis in Children from the Standpoint of the Surgeon,” Boston Medical and Surgical Journal 187, no. 13 (28 September 1922): 470-72.

312. AGN, SB, Sanatorio Marítimo, Legajo 103, August 12, 1900. 
playing as a tool to measure their healthiness. While tuberculosis prevention guides encouraged exercise, they also warned children against "too much exercise," due to the fear that cooling off from rigorous play too quickly facilitated the catching of a cold. ${ }^{313}$ Medical staff at the Asilo monitored the children's play to ensure they did not over exert themselves.

Figure 4.3: Recumbent children sunbathing ${ }^{314}$

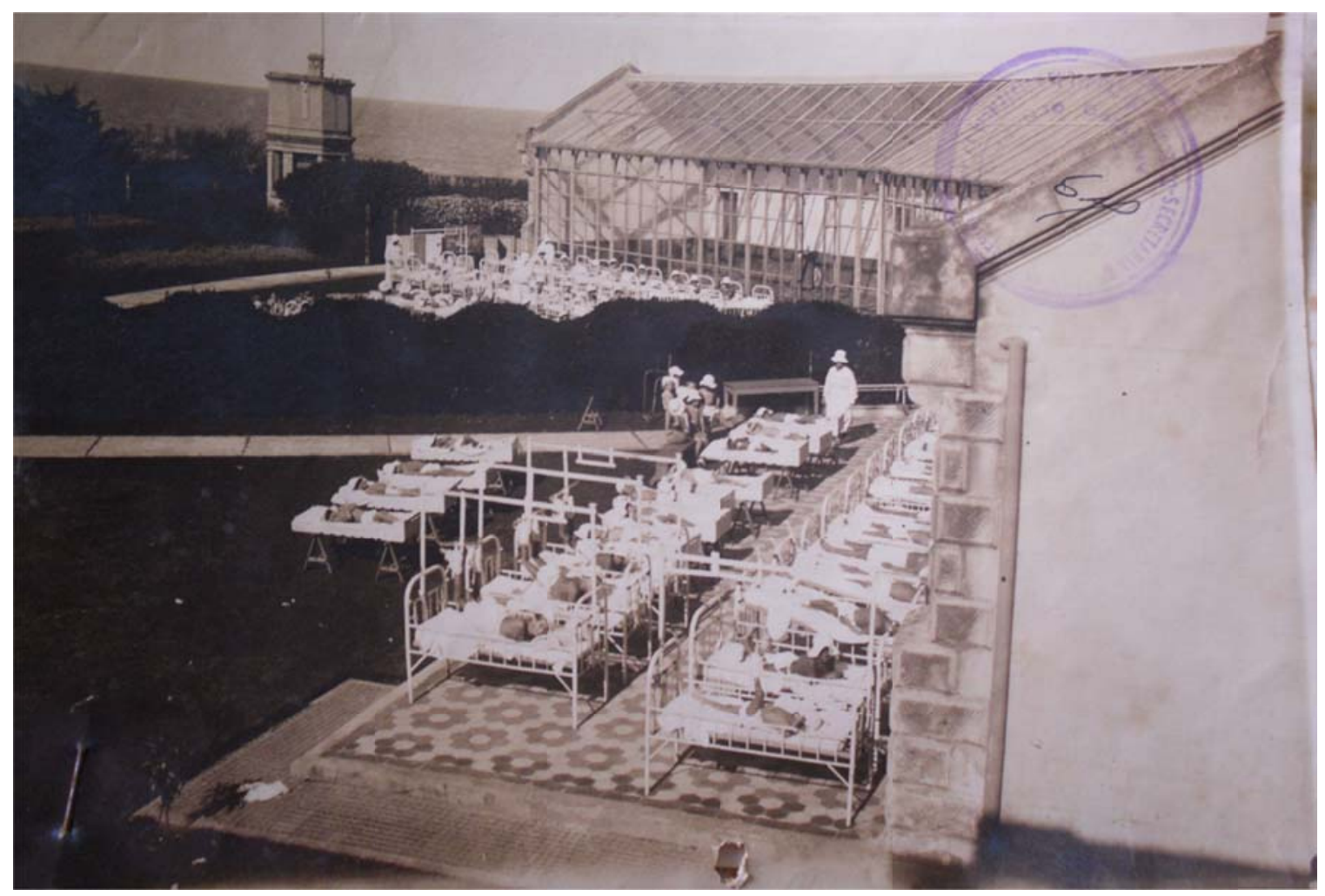

The Sociedad described the condition of the children that entered the Asilo in 1901, as “miserable orphans" abandoned in the beds of the Hospital de Niños or the Casa de Expósitos. The children were, "immobile in bed” and “ nauseated,” with open sores

313. Frost and O'Shea, The Great White Plague, 40.

314. AGN, SB, Solarium de Mar del Plata, Legajo 97, Foto de los niños en el Solarium, 1935. 
and aching bones. They spent their days and nights in pain, unable to sleep and without the consolation of "maternal affection."315 However, not all families abandoned their children. Families sometimes visited, bringing gifts of toys or candy. Others wrote letters checking on the condition of their children. In one report, the staff answered 45 letters to families asking about their children. ${ }^{316}$ Yet, the children of the Casa de Expósitos received no letters and did not have families visit them. While their treatment at the Asilo appeared similar, there were in fact, differences. They were typically kept in separate quarters and there are hints that those quarters were less adequate than facilities for children with parents. Dr. Jara noted in one report that the infirmary occupied by the children from the Casa de Expósitos was “small, dark, poorly ventilated and humid.”317 Alvarez, in her analysis of the Asilo, noted that children suffered in similar circumstances differently. Children who came from the hospital returned to their families, yet the foundlings remained institutionalized. ${ }^{318}$

While the daily routines of the children often appeared inflexible and painfully dull, there are many signs that the children also enjoyed some of their time at the Asilo. Notes on the condition of the children often mention that they were happy and playing. In one early note, the staff commented on the delight of the children, "at the end of the day, they are already thinking of tomorrow, to return to the sea and play." ${ }^{319}$ The

315. AGN, SB, Sanatorio Marítimo, Legajo 103, April 1, 1901.

316. AGN, SB, Solarium de Mar del Plata, Legajo 97, January 91928

317. AGN, SB, Sanatorio Marítimo, Legajo 103, August 12, 1900.

318. Álvarez, “La Experiencia de Ser un ‘niño Débil y Enfermo’,” 24.

319. AGN, SB, Sanatorio Marítimo, Legajo 103, Informe Mensual, April 16, 1893. 
Sociedad kept a record of donations to the Asilo and often reported donations of gifts for the children. Despite seemingly strict nutrition regimens, the Asilo received many donations of chocolates, caramels and other sweets for the children. ${ }^{320}$ The children also received many donations of toys and storybooks year round, but especially around the holidays. ${ }^{321}$ One Christmas, the Club General Pueyrredón donated over 100 toys to the institution. ${ }^{322}$ While the types of toys are not always described, some photographs of the children playing show us that they received beach toys, such as sand buckets and shovels (See Figure 4.4).

Figure 4.4: Children playing on the beach at the Asilo Marítimo ${ }^{323}$

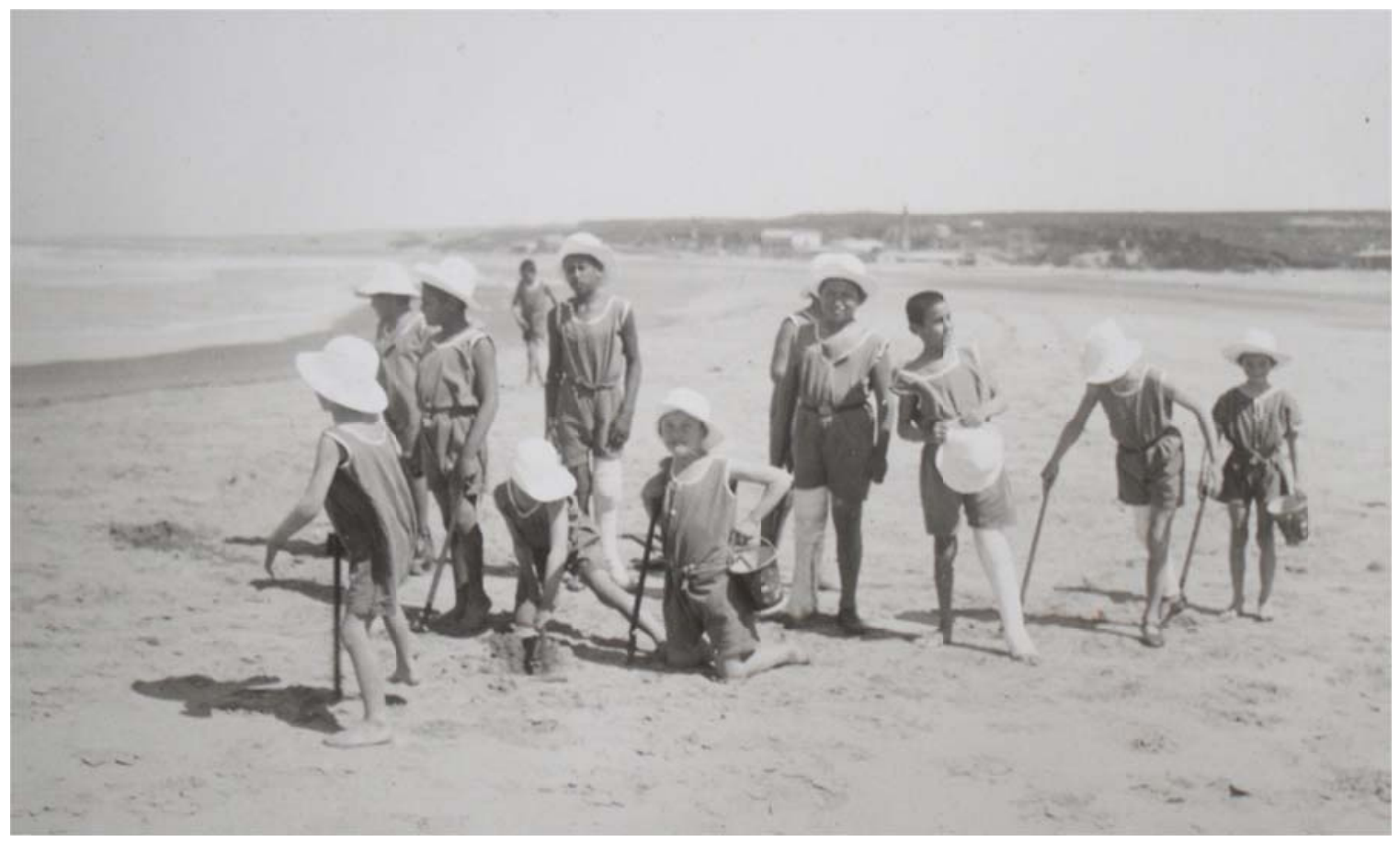

320. AGN, SB, Solarium de Mar del Plata, Legajo 96, April 15, 1926; June 5, 1926.

321. AGN, SB, Solarium de Mar del Plata, Legajo 96, April 5, 1926.

322. AGN, SB, Solarium de Mar del Plata, Legajo 96, January 6, 1927.

323. AGN, SB, Solarium de Mar del Plata, Legajo 97, foto de los niños jugando en la playa, 1935. 
Most official photography of the Asilo demonstrates the hygienic conditions of their childhoods, with the children lying in bed, lined up in the sun or receiving sanitary treatment. However, a rare set of candid photographs taken in the 1930s reveals a lighter side. The children, playing on the beach, appeared happy and many were smiling (See Figure 4.5). They buried each other in the sand, and one even reveals a child holding hands with one of the Asilo staff members. While these moments are not often discussed in the official discourse, we can imagine that at times, the children enjoyed their time at the Asilo and emotionally connected with their caregivers.

Figure 4.5: Children playing in the sand at the Asilo Marítimo ${ }^{324}$

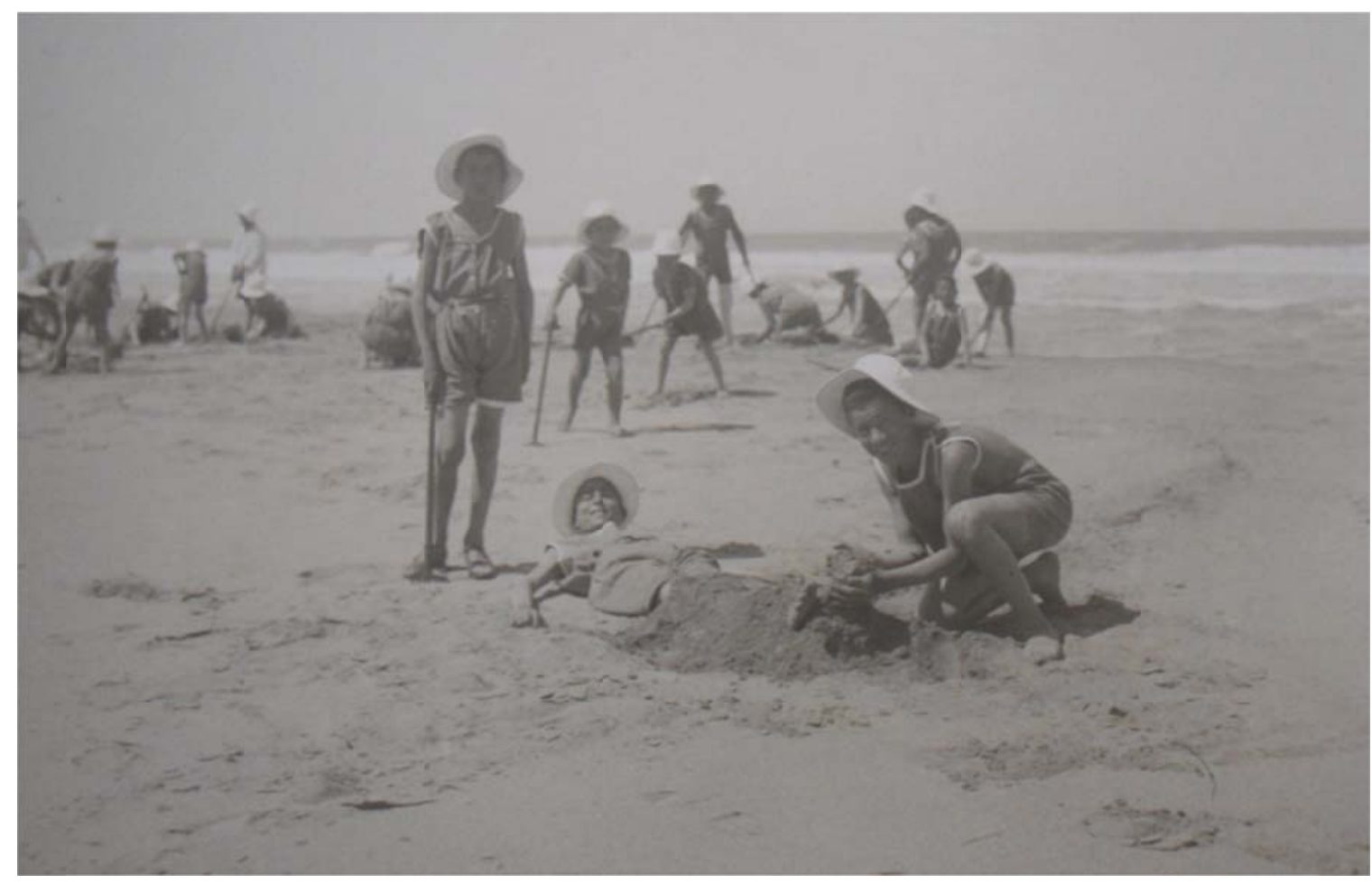

324. AGN, SB, Solarium de Mar del Plata, Legajo 97, foto de los niños jugando en la playa, 1935. 
Children stayed at the Asilo until they recovered from their illness or were well enough to continue treatment at home. This took months, or in some cases, years. Typically every few months, a large number of children would return to Buenos Aires by train, either back to their families or in the case of foundlings, back to the Casa de Expósitos. The construction of childhood at the Asilo provides an example of the participation of the Argentine medical community in defining the landscape of a healthy childhood in the first half of the twentieth century. Concerns over tuberculosis served to create healthful spaces outside of the city, redefining the boundaries of healing and rehabilitation. While the children at the Asilo experienced suffering and joys differently at the institution, their hygienic regime and climactic treatment were similarly designed to instill the children with hygienic practices and a spiritual morality that they would carry with them into adulthood. The treatment of tuberculosis as an urban social problem further reveals how definitions of space and place contributed to understandings of health, society and childhood. 


\section{CHAPTER V}

\section{CONCLUSION}

Planned environments for children, in late nineteenth and early twentieth century Argentina reveal much about historically specific constructions of childhood, bound by social, economic and political contexts. Play, and ideas about play, were at the heart of these constructions. As this dissertation has attempted to demonstrate, concepts of play came to be accepted as both central and necessary to the development of "normal” and "healthy" childhood landscapes. At the same time, landscapes of play served as conduits to express state and elite concerns about urban society, especially regarding the education, hygiene, and behaviors of the socio-economic lower classes.

This dissertation has examined the scope of urban transformation in Buenos Aires at the turn of the nineteenth century and revealed how the city served as a playground for planners, reformers and politicians to experiment with ideologies of childhood, modernity and nationhood. Liberal elite aspirations to “civilize” society were expressed through various efforts to define socio-spatial boundaries, improve the "hygienic" conditions of the “dangerous” landscape and construct a unified national identity within the built environment. As Buenos Aires grew demographically, concerns over overcrowded, unhygienic conditions fueled efforts to construct alternatively "healthy” landscapes to counteract the many urban social problems connected to its growth. The case studies that I presented in this study - experimentation with kindergartens, the growing parks movement and the push for respite care facilities outside of the city - served as examples of new spaces constructed to prevent and cure urban social problems. Each was connected to the belief that public health and sociability rested on access to outdoor space 
and normative implementations of childhood recreation. Through the examination of the production and negotiation of these spaces for children, I revealed how public and private actors experimented with and defined modern childhood in Argentina, often through the construction of idealized rehabilitative environments for the socio-economic lower classes.

Play-inspired pedagogy, especially those methods implemented in kindergartens, reflected the early Pan-American aspirations of the new school movement in Argentina. Froebel's concepts of play - learning through self-activity and discovery provided reformists with a space to articulate their definition of a healthy, normal Argentine childhood, often juxtaposed to that of the immigrant family. While kindergartens expanded widely amongst the middle and upper classes in North America, their proponents met resistance in Argentina and focus appeared more on transforming the habits of immigrant mothers. Conflicts also existed between Froebelian disciples and educators that found strict adherence to his methodology as too foreign. Still, the conception of play and recreation as paramount to childhood formed a major tenet of urban public health by the turn of the nineteenth century, and increasingly Froebel's ideas were resurrected in later decades.

The often-unequal development of parks and playgrounds also suggests the ways in which state actors used public space to transform the working class. While new parks widened working class children's access to leisure, they also served to sanitize urban space and establish socio-economic barriers. Emphasizing the impact on the southern barrios in Buenos Aires, open-air schools provided a space for elites to articulate the immigrant "other" in need of rehabilitation to a "normal” and "healthy" Argentine 
childhood. The Pan-American playground movement, articulated to improve children's health, also served to create boundaries on children's movement throughout Buenos Aires and curb perceived "delinquent" behaviors.

The development of kindergartens, playgrounds and open-air schools revealed the intersection of discourse on childhood, health and recreation within the urban landscape. These hygienic, outdoor spaces provided a solution to the perceived social problems of the urban poor within the city, and positioned the state as the arbitrator between elite aspirations and the needs of the socio-economic lower classes. By the twentieth century, both public and private actors established new landscapes of childhood outside of the city in an effort to remove and rehabilitate children's poor health and behavior. The Asilo Marítimo in Mar del Plata serves as an example of one such site constructed for "weak" and tubercular children. The medical community encouraged climactic treatment for childhood tuberculosis, presenting the landscape as integral to healing. The urban environment then was presented as the "other," redefining the boundaries of healing and rehabilitation. These early twentieth century sites provide a glimpse into the ways that normative notions of childhood, aimed at transforming the immigrant working class, were constructed into the Argentine landscape. Concepts of children's play continued to serve state interests well into the twentieth century, and I conclude by examining Peronist state designs of civic and republican themed spaces aimed to indoctrinate children into political life. The continuity of the impulse to link state and family life across political spectrums is revealed. In other words, cases in the early twentieth century that make up the bulk of this dissertation, provide a prelude to 
show how different political cultures continue to breed the normalization of childhood and the disciplining of the lower classes through the constructed environment.

\section{Peronist Visions of Childhood}

The global economic crisis of the 1930s led President Justo (1932-1938) to implement new economic policies expanding the role of the state. Rapid internal migration from the rural interior to Buenos Aires also increased the visibility of the working classes. Fear of social conflict between the industrial elite - the benefactors of state involvement - and the growing working class, spawned discussions of "social justice,” part of a Catholic reformation movement that viewed state involvement as the solution to socio-economic problems. ${ }^{325}$ The 1949 revisions of the Argentine Constitution reinforced these efforts and emphasized the Peronist call for "social justice" which rested on pushing socio-economic advances to widen notions of citizenship to the working classes. ${ }^{326}$ During Juan Perón’s first elected presidency, from 1946-1952, the government relied on calculated manipulations of public life to centralize its authority and limit opposition to the single-party state. Under the discourse of national unity, social justice, expanding political participation and widening access to urban space, the state took on a number of public works projects under two five-year plans of national reorganization. Alongside major extensions of transportation and infrastructure, geared

325. Mariano Ben Plotkin, Manana es San Peron: A Cultural History of Peron's Argentina (Wilmington, Del: Scholarly Resources, 2002), 10-13.

326. Republica Argentina, “Constitución de la Nación Argentina” (Buenos Aires: Subsecretaria des informaciones de la Presidencia de la Nación, 1949). 
to move Argentina into a modern industrial state, millions of Argentines were incorporated into education and social assistance programs. ${ }^{327}$

The state consolidated its efforts of increased state involvement through the implementation of two five-year plans, initiated in 1947 and 1952. Children and youth formed an integral component of both plans. The first included national reorganization and centralization of state authority over children's lives, emphasizing widening access to spaces of education, socialization and recreation. The state constructed schools, appropriated lands for public use - for parks and amusement - and organized youth recreation programs. Catholic education was also institutionalized in urban public schools, a movement that began in the 1930s. ${ }^{328}$ The second period, beginning around 1950, increased state curricula control over public education, incorporated the teaching of official Peronist doctrine and rejected non-National literature. ${ }^{329}$ This era culminated in a conflict between Perón and the Catholic Church - and a military coup ultimately overthrowing Perón in 1955. ${ }^{330}$

Internal migration from the countryside in the 1930s created a new urban working class steeped in Catholic tradition, different from the existing predominately European

327. Juan Carlos Torre, “La Democratizacion del Bienstar,” in Nueva historia argentina: los anos peronistas (1943-1955), ed. Juan Carlos Torre (Buenos Aires: Editorial Sudamericana, 2002), 292.

328. See Chapter III “Educación” of “Gobernación del Estado” in Presidencia de la Nación, "Plan de Gobierno 1947-1951 Tomo I,” Edición facsimilar 1946 Plan de Gobierno Argentina (Buenos Aires: Secretaría de Cultura de la Nación, 1947), 117-64.

329. See Chapter 4 “Educación” of “Capítulo I. Acción Social” in Presidente Perón, “2* Plan Quinquenal de la Nación 1953-1957,” Edición facsimilar 1954 Ley N.* 14.184 (Buenos Aires: Secretaría de Cultura de la Nación, 1954), 487-93.

330. David Rock, Authoritarian Argentina: The Nationalist Movement, Its History and Its Impact (Berkeley, CA: University of California Press, 1993). 
urban labor force. The populist nature of Peronism promised democratic reforms and political representation for all Argentines and appealed to the new urban work force. Perón’s “New Argentina” provided major welfare reforms for its youngest and oldest citizens, granted female suffrage, and increased access to education and health care. Despite this, increased state control over information and repression of opponents to Peronism turned his democratically elected presidency into dictatorship. ${ }^{331}$

In the 1949 Constitution, an autonomous ministry of education was created, centralizing state authority over schools. Nationalists, heading the new ministry, removed the long-standing tradition of secular education in Buenos Aires and emphasized instead the nuclear Catholic family in school curricula. ${ }^{332}$ After 1950, teachers were required to choose only from a state-approved list of textbooks, often filled with Nationalist imagery of the "New Argentina" and its leaders, Juan and Eva Perón. In one state-approved primary school textbook, the author states "President Perón, just as papa is for the children, is for all the Argentine men, working for the nation as a laborer.”333 The image of Perón as the "first laborer” appeared often, set to unite the people under one leader and promote labor for the good of the Argentine nation.

In 1950, at a weeklong conference of provincial governors to discuss the strategy of the Peronist party for the following 1952 election, Eva announced that children learned

331. Herbert L. Matthews, "Fascist Parallels Seen In Peronism,” The New York Times, 23 March 1951, 5; Mariano Plotkin, “The Changing Perceptions of Peronism,” in Peronism and Argentina, ed. James P. Brennan (Wilmington: SR Books, 1998), 29-54.

332. Republica Argentina, “Constitución de la Nación Argentina”; Monica Esti Rein, Martha Grenzeback, trans., Politics and Education in Argentina 1946-1962, Latin American Realities, Robert M. Levine, Series Editor (Armonk, New York: M.E. Sharpe, 1998).

333. Blanca Alicia Casas, "El Alma Tutelar,” Texto de lectura para primer grado superior (Buenos Aires: Luis Lasserre, 1953), 10-11. 
to say “Perón” before they learned “papa”. ${ }^{334}$ School curricula reinforced Eva’s

sentiment, that Perón was the father, and Eva the mother, of the "New Argentina," raising

the children to be loyal working citizens. Eva indeed acted as the social mother of the

nation, and even after her death in 1952 was regarded for her mythical and spiritual

guidance. "Just as your mother is the guardian angel of the house. She [Eva] is the

guardian angel of children.”335 Textbooks, toys and posters reinforced Perón and Eva’s

cult of personality while also strengthening the concept of parental authority. The

Fundación Eva Perón, initiated in 1948, fashioned new spaces of education and recreation

for Argentina’s working class children. The foundation organized social assistance

programs for women and children, bridging a perceived gap between the Peronist state

and the working class home. The second five-year plan emphasized the state and family

working together to raise disciplined Peronist children. It aimed to strengthen traditional

Catholic gender roles, exalting the mother's functions within the home as most important.

The accomplishments of Eva's foundation were celebrated in textbooks,

emphasizing the positive impacts Eva had on working class childhoods. "She organized

soccer matches, donations of toys, beautiful parties.... She constructed schools, homes,

playgrounds, parks, and she created a dream city she named the ‘Children’s City’”. 336

334. Milton Bracker, “PERON ‘LEADERSHIP’ DEFINED TO PEOPLE, Argentine President and Wife Identify Their Party and Aim With the Nation,” New York Times, 19 June 1950, 22.

335. Casas, “El Alma Tutelar,” 10-11.

336. Rein and Grenzeback, Politics and Education, 59 Rein mentions the children’s magazine, Mundo infantil, as referencing the "happenings at the 'Children's City', which Evita had established near the city of La Plata”. However, I believe Rein is confusing the Children’s City (located in Belgrano and completed in 1949) with the Children's Republic (located in La Plata and completed in 1951). The issues of Mundo infantil cited were published in 1949 and 1950, and fit the timeline of the Evita's Chidlren's City in Greater Buenos Aires. Regardless, Rein provides an excellent overview of the indoctrination of Peronism through elementary school textbooks in the second presidency of Juan Peron. 
Textbooks and iconic images reminded children to be grateful for the spaces they were given by the Peronist state. They perpetuated the image of a good Peronist child as one who was proud of their place in society, and who vowed to give back to the state what the state had provided for them. In a speech given by Perón celebrating National Youth’s Day, he reminded children of both their privilege and responsibility to national interests. ${ }^{337}$

By linking family and state, Peronist politics widened notions of citizenship to the working classes and to women. Even as female suffrage passed in the 1952 election, gender roles continued to be reinforced by Catholic tradition. The state reminded women to be like Eva, nurturing, loyal and passive to their leader, Perón. The state institutionalized educational reform and massive welfare efforts to ensure that working class children felt the rewards of the growing Peronist state. New spaces of leisure and amusement, created for children during Perón’s first elected presidency, aimed to unify the children of Argentina under one Peronist national identity. Eva even reformed the Sociedad de Beneficencia, the traditional philanthropic welfare society run by elite Catholic women. ${ }^{338}$ Eva assumed control over the society after they protested her honorary status as the President's wife within the organization. They criticized Eva for her illegitimate childhood status and her former career as an actress. As the last chapter describes, the Sociedad created institutions for orphans and the poor that were typically closed from the rest of society. They taught their children to be modest and submissive

337. Juan Domingo Perón, “En un Almuerzo Realizado en Olivos, con Motivio del Díra de la Juventud,” Speech (1949).

338. Karen Mead, "Beneficent Maternalism: Argentine Motherhood in Comparative Perspective, 18201920,” Journal of Women's History 12, no. 3 (Autumn 2000): 120-45. 
to their position in society. ${ }^{339}$ For Eva, working class children deserved to not only be celebrated, but also taught how to improve their status in society.

Eva's foundation constructed la Ciudad Infantil for children aged two to seven for parents experiencing hardships and needing long or short-term help with childcare. The “city” took up two blocks in Belgrano, a suburb of greater Buenos Aires, and housed approximately 400 children. The foundation converted an entire block into an outdoor playground and included an electric train and a swimming pool. The other block featured dormitories, classrooms and a dining hall. Most impressively, the design included a miniature sized play city where children could act out future societal roles. Miniature representations of a city hall, a bank, a police station, a shopping center and a church brought international recognition to la Ciudad Infantil.

Children acted out different roles within the community every day as teacher, mayor, banker or some other role that provided direct participation in their preparations to be integrated into society. Children could even drive their pedal cars up to a gas station and ask the attendant to "fill up". ${ }^{340}$ The foundation provided the children with elaborate housing and expensive clothing and toys. In contrast to the Sociedad, the Foundation expressed how it provided the children in Eva's city with new clothing from the best designer shops in Buenos Aires, rather than the white smocks so often worn by children in institutions of the Sociedad. Critics of Peronism argued that purchasing expensive clothes and toys provided "excessive treatment” for the working class children.

339. Mead, "Beneficent Maternalism”; Nicholas and Marysa Navarro Fraser, Evita (New York: W. W. Norton and Company, 1996).

340. Dolane Larson, “Fundacion Eva Peron: Education - The Amanda Allen Children’s City,” summary, Fundacion de Investigaciones Historicas Evita Peron (2002), Http://www.evitaperon.org. 
Eva often refuted statements of her critics as elitist, and commonly proclaimed that, "the only privileged are the children.”341

Adjacent to la Ciuadad Infantil, the foundation constructed another larger city, La Ciudad Estudiantil. The construction spanned four blocks and provided housing and secondary education for boys in leadership training and technological skills. La Ciuadad Estudiantil also contained miniature reproductions, such as a replication of the Casa Rosada. The foundation emphasized the student's participation in governance; the students chose a president, ministers and diplomats. Some students even formed part of the nightly security patrol to protect social order. ${ }^{342}$ Peronist doctrine raised work as an important Argentine value, and the boys were taught to work and participate in governance, so to be rewarded by Perón. ${ }^{343}$

These spaces were important tools in reproducing Peronist doctrine, both for children in Argentina and to an international eye. International visitors often toured the famed miniature cities, and Eva's foundation became the target of both praise and criticism abroad. The New York Times published several pieces on the first lady's generous contributions to children in the international community. They documented her “whirl-wind tour” of Europe in conjunction with the United Nation's Children’s Relief fund to help feed and cloth children in parts of Europe and Asia. As well, they questioned her controversial contributions of expensive designer clothing to homeless

341. Fraser, Evita, 113-36.

342. Dolane Larson, “Fundacion Eva Peron: Education - Student’s City,” summary, Fundacion de Investigaciones Historicas Evita Peron (2002), Http://www.evitaperon.org. 343. Matthews, "Fascist Parallels Seen In Peronism.” 
children in Washington DC. ${ }^{344}$ These constructed spaces of childhood acted as

important symbols in building an international image that within the state of the "New" Argentina, the fashioned youth were loyal Peronist citizens.

\section{La Republica de Los Niños}

Eva's foundation began the construction of an amusement park, La Republica de los Niños, or the Children’s Republic, just after la Ciudad Infantil was inaugurated in 1949. While la Ciudad Infantil only took five months to build, la Republica de los Niños took three years to construct, completed in 1951. It was a much larger undertaking than its Buenos Aires counterparts, and its construction took the labor of 1600 workers. ${ }^{345}$ The amusement park, designed to replicate the modern Argentine nation, represented both the urban and rural landscape of the country. Originally the park consisted of nearly 24,000 acres for public use, but was reduced to nearly half that with privatization of the surrounding area around 1955 . The property used for the project once served as a golf course belonging to a British meat packer named Swift. It is unclear when the province appropriated the lands, but part of Perón's plan of national reorganization included the nationalization of several foreign industries including the British owned railway. Perón spoke at the parks inauguration in $1951 .^{346}$ Famed as the first amusement park in the

344. Kathleen Teltsch, “SENORA PERON'S AID FOR FUND OFFERED,” New York Times, 7 January 1948, 8.

345. The provincial governor of Buenos Aires, Domingo Mercante, played an important role in constructing La Republica de los Niños. Concerned for children's health and hygiene, he also assisted in the establishment of the 1949 constitution.

346. Documentation on the Republica de los Niños can be found at the Palacio Municipal in the municipality of La Plata, however time restrictions prevented their exploration for this dissertation. The park began as a provincial undertaking, but was transferred to the municipality of La Plata in the 1970s. Municipalidad de la Plata, "Historia del Proyecto," Historia de La Republica de los Niños, summary (Palacio Municipal, La Plata, Buenos Aires), http://www.republica.laplata.gov.ar/historia/inicio.htm. 
Americas, it is widely circulated in Argentina today that la Republica los Niños served as the inspiration for Disneyland after Walt Disney met with Perón and toured the park. ${ }^{347}$ The park primarily served two purposes. First, it provided a public space for underprivileged working class children to play in the vast green spaces and find inspiration in the European inspired buildings and fairy tale images representing the most popular childhood tales in Argentina. ${ }^{348}$ Second, it taught children the essential elements of democracy through direct participation. Children from throughout the provinces governed the miniature republic, learning Peronist notions of citizenship.

Within the park's civic center, located in the urban zone, existed the most important government institutions replicated in miniature form. Not unlike the design of the centers of civic activity in La Plata or Greater Buenos Aires, la Republica de los Niños housed the government, Church and bank. A large plaza, for gathering, donned a statue of José San Martín commemorating the leader in the nation’s independence movement. A pedestrian street lined with castles, palaces, shops and restaurants provided more amusement.

The urban zone emphasized a cosmopolitan European culture. The legislature resembled the English Parliament and another building replicated the Taj Mahal. In the Gothic styled church, a mural above the altar represented the fundamental principles of

347. "Una Republica a la Medida de los Chicos; Magica Leyenda: La Ciudad Que Inspiro a Walt Disney,” Hoy Interes General, La Plata (2 agosto 2004): 12.

348. These included stories of the Brothers Grimm and Mark Twain. The influence of European and American authors on the park is unique to the governorship of Domingo Mercante, who participated in its construction, since after 1952, the state banned these authors from schools. The succeeding provincial governor, Carlos V. Aloe, criticized Mercante for allowing such "treason" in the school system. He declared a lack of nationalism in the schools and called for a ban on all foreign authors. Edward A. Morrow, "ARGENTINES TABOO GRIMM AND TWAIN; Peron Leader Says Their Works and That of Other Writers Plant ‘Treason’ in Schools,” New York Times, 3 July 1952, \. 
the Roman Catholic Church, which were often reinforced through Peronist doctrine. There was even a police station and a jailhouse to represent order and authority. The first children’s radio station, “The Republic’s Radio” aired from the urban center, emphasizing the importance of radio in spreading the Peronist message to the people. Masses of children gathered in the civic center during the parks inauguration, in a display not unfamiliar to the people of Buenos Aires. The state held rallies of workers typically in the plazas in front of the Casa Rosada as a visual demonstration of the popular support for Perón’s leadership. ${ }^{349}$

In between the urban and rural zones, there was a market, close to the train station, providing a connection from the civic center to the activities in the rural zone. The railway circled the large open green space that represented the activities of the countryside. In the rural zone, children learned various skills required of the agricultural economy. Children worked with animals and learned how to milk cows and manufacture cheese. They also practiced woodcutting and fishing skills. Additionally, located in the rural zone, was an area specifically designated for recreation and amusement rides. The rural sector connected to nature, and families used the space to ride horses and bicycles, or to play soccer. Children took rides around a large lake in the rural sector on a replica of a traditional Mississippi River boat, based on one of Twain’s

\footnotetext{
349. n.a., "Se Inaugura la 'República de los Niños,' en Gonnet, Localidad Cercana a La Plata. Estuvieron Presentes Miles de Escolares,” Photograph, enfrente de la casa gobierna, Eva Peron - Mujer Leyenda Imagenes de Evita (1951), Http://mariaevaperon.blogspot.com/2007/03/ms-imagenes-de-evita.html.
} 
stories. When the children returned from the boat rides, they even passed through a mock customs house. $^{350}$

Much like in la Ciudad Infantil and la Ciudad Estudiantil in greater Buenos Aires, la Republica de los Niños encouraged young people to mimic the roles of adults.

Children from schools throughout the province of Buenos Aires participated in a mock government, held elections and debated over issues and themes related to governance, such as the passing of various laws. All the buildings were constructed to the size of a child, so that an adult entering the buildings would have had to duck. Children participated in governmental offices, in the departments of treasury, public service, foreign relations, defense, and health and social action. ${ }^{351}$ The consistently dual nature of representations of both urban and rural sectors of Argentina points to the integrated nature of the national for the "New" Argentina. The agricultural sector provided the natural space for production, while the urban sector provided the major institutions of governance and industry. The market bridged these two sectors. In the form of direct participation, children from all over the provinces were unified within this space.

In la Republica de los Niños, the "New” Argentina provided a space where ordinary working class citizens could rise to important positions of governance and benefit from their productive contributions to society. The essential mechanisms of propaganda used by the Argentine state were emphasized to gain support. Elaborate

350. Municipalidad de La Plata, “Mapa,” Plano del Predio de La Republica de los Niños, map (Palacio Municipal, La Plata, Buenos Aires), http://www.republica.laplata.gov.ar/mapa/inicio.htm.

351. Municipalidad de La Plata, “Edificios,” Edicicios de La Republica de Los Niños, summary (Palacio Municipal, La Plata, Buenos Aires), Http://www.republica.laplata.gov.ar/edificios/inicio.htm. 
prizes could be won and massive posters and images of Perón and Eva surrounded all the various activities available to children in the park.

\section{Play and State Indoctrination}

The state organized its first soccer tournament in 1948, and over 15,000 boys participated in the soccer competitions. After 1952, they added other sports and also

admitted girls. Later, they formed a separate organization for teenagers. ${ }^{352}$ The documentary, “Perón, sinfonía del sentimiento,” shows video footage of Eva and Perón at the River Plate Stadium during a soccer competition shaking hands with the smiling boys. Eva even gave the first kick of the game. The stadium appeared full of energy and excitement, not unlike that which you could find in Buenos Aires today. In the usual Peronist manner, everyone sang a song of praise for Eva and stood for the national anthem. $^{353}$

The state also organized children into teams from each of the neighborhoods in the provinces, and encouraged the teams to pick nationalistic names. The Eva Perón Foundation provided equipment, uniforms, and free transportation to Buenos Aires to compete. The tournaments provided a link for the state to extend its reach to children even in the more rural provinces. The tournaments not only brought together children from various provincial regions, but also provided a greater link between socio-economic classes. These children received free health exams, and though this allowed many children access to recreation and equipment once denied them, it also increased the

352. Mariano Ben Plotkin, Manana es San Peron, 181.

353. Leonardo Favio, Perón, sinfonía del sentimiento, documentary, Producer Victor Bassuk and Javier Leoz (Argentina, 1999). 
state's control over their everyday lives. Under these health initiatives, for example, the children were required to be registered with the police.

The official discourse of the state argued that the tournaments united the Argentine youth under the auspices of Peronism. ${ }^{354}$ An international newspaper presented a boys’ soccer championship as “transcending any world series game.” It also reiterated the importance of Eva at the events, "Senora Perón herself raised the flag and was the heroine of the day. For the tournament was the latest evidence of the extent to which the Ayuda Social (the Eva Perón Foundation) ... has entered Argentine life.»355 Time Magazine described the "red-hot enthusiasm" for soccer in Argentina in 1948, explaining that in Buenos Aires alone there were 40 soccer stadiums and fields. It also referenced the tangled web of sports and politics through a recent strike that had occurred against wealthy clubs buying up and trading players at will. "At exactly 3:45 p.m., in every stadium in Argentina, all players abruptly stood stock-still for one minute, then went on with the game." ${ }^{356}$ The ties that existed between politics and sports allowed the foundation to successfully use the children's tournaments to rally support for the Peronist party. A New York Times article pointed to the controversy over the foundation's finances and its identification with Eva Perón, stating “overall is the feeling that by virtual identification of all public welfare work in the country with Senora Perón

354. Mariano Ben Plotkin, Manana es San Peron, 184-85.

355. Milton Bracker, “TOURNEY A TRIBUTE TO SENORA PERON, Foundation Bearing Her Name Conducts Gala Argentine Soccer Championship,” New York Times, 6 February 1950, 17.

356. unknown, “Time Out,” Time Magazine, 22 November 1948. 
personally, the Peronistas have added enormously to their political potential.” Despite this the author recognizes that "all the youngsters ... are having the time of their lives.”357 Historian, Mariano Ben Plotkin, has pointed to the importance of these events in the Peronist politicization of every day life. He argues that families and children passively consented to Peronist politics by participating in the tournaments. ${ }^{358}$ The same could be argued for the amusement park where children and families used the spaces for enjoyment, without actively showing support for the regime. As I have shown throughout this dissertation, increasingly throughout the twentieth century, concepts of children's play provided a platform to define modern childhood. Through the implementation of two five-year plans, the Peronist state consolidated its influence over working class childhoods, and redefined the imaginary "other" as one of the privileged. At the same time, the state used new state-sponsored recreation to present Peronist doctrine and passively indoctrinate the children of Argentina as loyal citizens.

Urban discourses and concepts of childhood continued to be challenged throughout the twentieth century. The authoritarian nature of Peronism led to many conflicts, and the dichotomy of politics between Peronism and anti-Peronism manifested itself physically after a military coup took power in 1955 . The military government banned Peronism and removed Peronist textbooks from schools. The military government destroyed la Ciudad Infantil, and used la Ciudad Estudiantil as a detention center for political opponents. They shut down La Republica de los Niños, and the park

357. Bracker, "TOURNEY A TRIBUTE TO SENORA PERON, Foundation Bearing Her Name Conducts Gala Argentine Soccer Championship,” 17.

358. Mariano Ben Plotkin, Manana es San Peron, 181. 
did not reopen until the 1970s. The strong influence of the Eva Perón foundation on these spaces and their removal from use by the military reveals the military's will to destroy anything associated with the Peronist state.

Increasingly since the nineteenth century, the state increased its influence over working class family life qua childhood. The Eva Perón Foundation, for example, functioned as an impressive tool of the state. It reiterated traditional Catholic gendered roles by presenting the state as a family, with a strong working male leader and an inspirational social mother doing good work for the nation. Crediting the Eva Perón Foundation, and therefore Eva, with these spaces of amusement and leisure for children further fueled the exaltation of motherhood and female suffrage. These spaces of amusement and leisure for the working classes were uniquely created. The Peronist state understood that it was a crucial element in the process of indoctrinating the growing youth of urban Buenos Aires as well as of the interior. Through the politicization of these spaces, and their attractive quality to the working classes, children passively accepted Peronist doctrine, while actively participating in mock forms of citizenry and competition.

The constitutional revisions of 1949 reflected the national interests of the state to intervene in the lives of underprivileged working class children through housing, education and health. In order to move them into the modern "New” Argentina," the state redefined both the roles of the child and the parent. The amusement park and sporting tournaments provided other manifestation of education for the working classes, beyond the classroom, by creating environments for children to "play" as adults but also to be monitored closely by the state. Peronist efforts to create new spaces of childhood 
intrinsically tied to developing new methods of social control - despite the discourse of widening access to political citizenship - the state made a clear effort to control national consciousness by controlling education and leisure culture.

The construction of new environments for children fashioned landscapes for reformers and planners to negotiate notions of modernity, childhood and nationhood in the nineteenth and twentieth centuries. State and municipal authorities increasingly built institutions regulating the domain of childhood - especially over the socio-economic lower classes - through the imagining of "normal" and "healthy" childhoods as filled with education and play. In the nineteenth century, liberal-elite normative conceptions of childhood increasingly defined the state as responsible for the rehabilitation of "abnormal" or "unhealthy" childhoods, under the umbrella of education and hygiene reform, for the greater good of the nation. These notions were sometimes challenged and negotiated between public and private interests. Especially in the 1920s and 1930s, cultural nationalists attempted to reinvigorate the role of the traditional Catholic patriarchal family alongside the centralizing power of the state. Again in the 1940s and 1950s, state power consolidated its efforts to define modern childhood to include the participation - and indoctrination - of the lower socio-economic masses. Even after the collapse of Peronist power, the destruction of Peronist spaces of childhood and subsequent decades of civil unrest, including the "dirty war" against perceived dissident youth, reveals the ways in which both the construction of space and the place of childhood held significant meaning to Argentina's nation-state development. Childhood thus reveals itself as a significant contested ideological space throughout the twentieth century, constructed and negotiated alongside notions of Argentine national identity. 


\section{REFERENCES}

\section{ARCHIVAL SOURCES}

Archivo General de la Nación Argentina

Policía de la Capital, Órdenes del Día

Sociedad de Beneficencia de la Capital

Biblioteca Nacional de Maestros Argentina

Consejo Nacional de Educación

\section{PUBLISHED PRIMARY SOURCES}

Allen, William H. Civics and Health. Boston: Ginn and Company, 1909.

Banchs, Enrique. “Escuelas para Niños Débiles.” El Monitor de la Educación Común, (1909): 677-97.

Bracker, Milton. “PERON 'LEADERSHIP’ DEFINED TO PEOPLE, Argentine President and Wife Identify Their Party and Aim With the Nation.” New York Times, 19 June 1950, 22.

— . "TOURNEY A TRIBUTE TO SENORA PERON, Foundation Bearing Her Name Conducts Gala Argentine Soccer Championship.” New York Times, 6 February 1950, 17.

“Bibliografia: El Niño y Su Naturaleza.” El Monitor de la Educación Común, no. 279 (Octubre 31 1896): 909.

Bilbao, Manuel. Buenos Aires Desde Su Fundación Hasta Nuestros Días. Buenos Aires: Imprenta de Juan A. Alsina, 1902.

Brown M.D., Lloyd T. "Tuberculosis in Children from the Standpoint of the Surgeon.” Boston Medical and Surgical Journal 187, no. 13 (28 September 1922): 470-72.

Buenos Aires Maps. "Plano de Buenos Aires 1870.”

Butterworth, Hezekiah. “The Kindergarten Age.” The Review of Reviews 14, no. 6 (December 1896): 681-86.

- South America: A Popular History of the Struggle for Liberty in the Andean Republics and Cuba. New York: Doubleday \& McClure Co., 1898.

Carpenter, Frank George. South America: Social, Industrial, and Political. New York: Western W. Wilson, 1900.

Carranza, Adolfo P. Razón del Nombre de las Plazas, Parques y Calles de la Ciudad de Buenos Aires. Buenos Aires: Litografia É Imprenta O. Kraft, 1895. 
Casas, Blanca Alicia. “El Alma Tutelar.” Texto de lectura para primer grado superior. Buenos Aires: Luis Lasserre, 1953.

Cassinelli, Luis R. “Los Juegos.” Monitor de la Educación Común (1916).

Champagne, Mildred. “The Children of Parque Lezama.” National Magazine an Illustrated American Monthly XLIII (October 1915 to March 1916 1915-16).

“Los Chicos de la Quema.” Caras y Caretas 11 (3 de Octubre 1908): 522-23.

“Child Labor Vs. Recreation.” The American Child: A Quarterly Journal of General Child Welfare 2, no. 1 (May 1920).

Cozzani de Gillone Elsa G. R. “Mensaje de Luz.” Texto de lectura para tercer grado. Buenos Aires: Editorial Estrada, 1954.

Coni, Emilio R., Presidente de la Comisión organizadora. Argentina Médica, Guía Médica é Higiénica. Buenos Aires: Imprenta y Casa Editora de Coni Hermanos, 1904.

Crespo, Dr. Don Antonio F., Intendente), Latzina, Francisco <compiler. Censo General de Población, Edificacion, Comercio É Industrias de la Ciudad de Buenos Aires Capital Federal de la República Argentina, Levantado en los Días 17 de Agosto, 15 y 30 de Setiembre de 1887. Tomo Primero. Buenos Aires: Campañía SudAmericana de Billetes de Banco, 1889.

Davis, Richard Harding. Three Gringos in Venezuela and Central America. New York: Harper \& Brothers, 1896.

Don Manuel J. Güraldes, intendente, Alberto B. Martinez, director. Censo General de Población, Comercio É Industrias de la Ciudad de Buenos Aires Capital Federal de la República Argentina, Levantado en los Días 16 al 24 de Octubre de 1909. Tomo Segundo. Buenos Aires: Campañía Sud-Americana de Billetes de Banco, 1910.

Dupaquier, Dr. E.M. “Department of General Medicine.” New Orleans Medical and Surgical Journal LII, no. 3 (September 1899).

Eccleston, S. C. “Nuestro Kindergarten.” Kindergarten Review 23 (October 1912): 12122.

Eccleston, Sara Chamberlain de, traductor. "Nuestras Hijas y el Kindergarten.” La Educación 13, no. 288 (1898): 210-11.

“Educacion Fisica: Los Recreos de los Niños.” El Monitor de la Educación Común Año XI, no. 184 (15 Julio 1890): 241-45.

“Exchange of Children’s Correspondence.” Normal Instructor XVII, no. 9 (September 1908): 7.

Feinmann, Enrique. "La Medicina Social y Los Problemas Del Trabajo En La República Argentina.” Read by Dr. Sarmiento Laspiur. Joint session of Subsection C of 
Section VIII and the American Sociological Association, December 30, 1915 in Proceedings of The Second Pan American Scientific Congress. Section VIII, Part I Public Health and Medicine, Monday, December 27, 1915, to Saturday, January 8, 1916, chairman William C. Gorgas, 540-87. Washington, U.S.A.: U.S. Government Printing Office, 1915.

Felipe, Daryl. “La Gimnástica Natural.” El Monitor de la Educación Común 11, no. 149 (ene. 1889): 421-23.

Froebel, Friedrich. The Education of Man. Josephine Jarvis. New York: A. Lovell \& Company, 1885.

Frost, William Dodge, and Michael Vincent O’Shea. The Great White Plague; Simple Lessons on Causes and Prevention, Intended Especially for Use in Schools. Madison: Democrat Printing Company, 1912.

Gomez, Justa. “Field Notes.” Kindergarten Magazine V, no. 2 (October 1892): 236-37.

Hirst, W. A. Argentina: The South American Series. London: T. Fisher Unwin, 1910.

“The International Kindergarten Union: Notes on the Colorado Tour.” Kindergarten Magazine VIII, no. 1 (September 1895): 29-38

Jara, J.H. “Memoria del Hospital y Asilo Marítimo (Mar del Plata).” In Memoria del Año 1906, Sociedad de Beneficencia de la Capital, 320-27. Buenos Aires, 1906.

“Los Jardines de Infantes.” Caras y Caretas II, no. 64 (23 de Diciembre 1899).

“El Kindergarten : Jardines de la Infancia.” Monitor de la Educación Común 9, no. 135 (1888): 682-86.

Lazerson, Marvin. "Urban Reform and Schools: Kindergartens in Massachusetts, 18701915.” History of Education Quarterly 11, no. 2 (Summer 1971): 115-42.

Lord, E. W. “The Playground A Necessary Accompaniment to Child Labor Restriction.” Third General Conference, Wednesday Morning, September 9 in Proceedings of the Second Annual Playground Congress, September 8-12, 1908, 119-28. New York City: Playground Association of America, 1908.

Lovejoy, Owen R. “Child Labor and Public Health.” Joint session of Subsection C of Section VIII and the American Association for Labor Legislation, Wednesday afternoon, Decebmer 29, 1915 in Proceedings of The Second Pan American Scientific Congress. Section VIII, Part I Public Health and Medicine, Monday, December 27, 1915, to Saturday, January 8, 1916, 276-83. Washington, U.S.A.: U.S. Government Printing Office, 1915.

López, Lucio Vicente. La Gran Aldea: Costumbres Bonaerenses. Buenos Aires, 1908.

Magold PhD, George B. Child Problems. New York: The Macmillan Company, 1914. 
Mann, Mary, and Sara Chamberlain de Eccleston. “El Kindergarten Ó La Nueva Educación, Por la Esposa de Horacio Mann.” Monitor de la Educación Común (1899).

Marenholtz-Bülow, Bertha Maria. The Child and Child-Nature. Syracuse, NY: C.W. Bardeen, 1895.

Matthews, Herbert L. “Fascist Parallels Seen In Peronism.” The New York Times, 23 March 1951, 5.

McFarland, Horace J. “The Human Side of City Planning.” Joint session of Subsection D of Section VIII and the American Civic Association, December 30, 1915 in Proceedings of The Second Pan American Scientific Congress. Section VIII, Part I Public Health and Medicine, Monday, December 27, 1915, to Saturday, January 8, 1916, 385-87. Washington DC: U.S. Government Printing Office, 1915.

Montefiore, Therese G. The Ethical Teaching of Froebel as Gathered from His Works. Two Essays. London: Kegan Paul, Trench \& Co., 1890.

Morrow, Edward A. “ARGENTINES TABOO GRIMM AND TWAIN; Peron Leader Says Their Works and That of Other Writers Plant 'Treason' in Schools.” New York Times, 3 July 1952, 5.

Municipalidad de la Ciudad de Buenos Aires. Censo general de población, edificación, comercio e industrias de la Ciudad de Buenos Aires 1909. Buenos Aires:

Compañía Sudamericana de Billetes de Banco, 1910.

Murray, May, ed. "Kindergarten Exhibit, South America.” The Kindergarten and First Grade 1 (September 1916): 279-326.

Nelson, Ernesto. Las Plazas de Juego para Niños. Extracto del Museo Social Argentino. Buenos Aires: Imprenta y Casa Editora de Coni Hermanos, 1913.

— . "The Secondary School and The University." General Session of Section IV, January 5, 1916 in Proceedings of The Second Pan American Scientific Congress, Monday, December 27-1915 to Saturday, January 8, 1916. Part 2 Education, edited by Glen Levin Swiggett. Washington, U.S.A.: U.S. Government Printing Office, 1917.

Norville, Hardynia K. “Temperance Sentiment Growing in the Argentine Republic.” The Union Signal XLIV, no. 33 (12 September 1918): 7.

Park, Roberta J. “‘Boys’ Clubs Are Better Than Policemen’s Clubs’: Endeavours by Philanthropists, Social Reformers, and Others to Prevent Juvenile Crime, the Late 1800s to 1917.” The International Journal of the History of Sport 24, no. 6 (June 2007): 749-75.

Perón, Juan Domingo. “En un Almuerzo Realizado en Olivos, con Motivio del Díra de la Juventud.” Speech, 1949.

. “2* Plan Quinquenal de la Nación 1953-1957.” Edición facsimilar 1954 Ley

N.* 14.184. Buenos Aires: Secretaría de Cultura de la Nación, 1954. 
Pizzurno, Pablo A. "Deficiencias de la Educación Argentina: Algunas Causas y Remedios.” La Educación XIII, no. 275 y 276 (Marzo 1 y 15 1898): 36-42.

“Plano del Nuevo Parque.” Caras y Caretas V (20 de Septiembre 1902).

Pratto, Salvador A. “Address of Dr. Salvador A. Pratto, Opening Address.” In The American International Congress on Tuberculosis, J. Mount Bleyer, 173-74. St. Loius: Medico-Legal Journal, 1904.

Presidencia de la Nación. “Plan de Gobierno 1947-1951 Tomo I.” Edición facsimilar 1946 Plan de Gobierno Argentina. Buenos Aires: Secretaría de Cultura de la Nación, 1947.

Republica Argentina. “Constitución de la Nación Argentina.” Buenos Aires: Subsecretaria des informaciones de la Presidencia de la Nación, 1949.

Roca, Julio. “Decreto Declarando Que los Gimnasios y Plazas de Juegos, Que Se Están Construyendo, Se Encuentran Comprendidos en la Exoneración Que Determina la Ley N²927.” Boletin de Obras Públicas de la República Argentina, Publicación del Ministerio de Obras Públicas, Tomo I, Num. I. Buenos Aires, 1900.

Ruggles, C. O. “Winona State Normal School, 1860-1910.” Written in connection with the preparation for the celebration of the Fiftieth Anniversary of the Opening of the Institution. Historical Sketch and Notes by C.O. Ruggles, Hisotry and Social Sciences, Assisted by Other Members of the Faculty. Winona, MN: Winona State University, 1910.

Segot, Sra. Elena. “Jardines de Infantes.” Sesión del 20 de Mayo in Conferencias Pedagógicas : Sección Doctrinal, Monitor de la Educación Común, 125-33, 1883.

Sociedad de Beneficencia de la Capital. "Reglamaneto del Hospital y Asilo Marítimo.” AGN. Buenos Aires, 1909.

Teltsch, Kathleen. “SENORA PERON’S AID FOR FUND OFFERED.” New York Times, 7 January 1948, 8.

“La Utilidad de la Gimnástica.” El Monitor de la Educación Común 3, no. 59 (Mayo 1884): 593-94.

Vidal, Antonia, and Charles Robertson. “The 'Open-Air School' in Scientific Pedagogy: Initiatives of the Argentine School System.” Session II - Open Air Schools. Fourth International Congress on School Hygiene. Buffalo, New York, 1913.

Vidal, Antonio, and Charles Robertson. "The 'Open-Air School' in Scientific Pedagogy: Initiatives of the Argentine School System.” In Fourth International Congress on School Hygiene. Vol. II, edited by Thomas A. Storey, 166-70. Buffalo, New York, 1914.

Weber M.D., Hermann. "Remarks on Climate and Sea Voyages in the Treatment of Tuberculosis. Read Before the International Tuberculosis Congress in Berlin." The British Medical Journal, 3 June 1899, 1321-24. 
“What We Don’t Know About South America: Dr. Ernesto Nelson of Argentina Points Out Many Common Interests and Talks of the Art and Literature with Which We Are Unfamiliar.” New York Times, 16 January 1916, SM7.

Willard M.D., De Forest. “Open-Air Treatment of Surgical Tuberculosis.” In Sixth International Congress on Tuberculosis, Washington September 28 to October 5. Vol. 2, 257-67. Philadelphia: William F. Fell Company, 1908.

Zinny, Antonio. “Jardines de Infantes, Kindergarten o Escuelas de Parvulos.” In Memoria del Departamento de Escuelas al Gobierno de la Provincia de Buenos Aires Corresondiente Al Año 1873. Buenos Aires, 1874.

Zuluaga, Custodia. "Los Conejitos:

Trabajo Leído en la A. I. de Kindergarten por la Señorita Custodia Zuluaga.” La Educación 13, no. 292-294 (1898): 297-99.

\section{SECONDARY SOURCES}

Ablard, Jonathan D. Madness in Buenos Aires: Patients, Psychiatrists, and the Argentine State, 1880-1983. Canada: University of Calgary Press, 2008.

Adelman, Jeremy. "Introduction: The Problem of Persistence in Latin American History.” In Colonial Legacies: The Problem of Persistence in Latin American History, 1-13. New York: Routledge, 1999.

- Republic of Capital: Buenos Aires and the Legal Transformation of the Atlantic World. Stanford: Stanford University Press, 1999.

Ailwood, Joanne. "Mothers, Teachers, Maternalism and Early Childhood Education Care: Some Historical Connections.” Contemporary Issues in Early Childhood 8, no. 2 (2007): 157-65.

Aitken, Stuart C. Putting Children in Their Place. Department of Geography: San Diego State University, 1994.

Allen, Ann Taylor. "Spiritual Motherhood: German Feminists and the Kindergarten Movement, 1848-1911.” History of Education Quarterly 22, no. 3 (Autumn 1982): 319-39.

Anderson, Benedict. Imagined Communities : Reflections on the Origin and Spread of Nationalism. London: Verso, 1983.

Ann Taylor Allen. "Children Between Public and Private Worlds: The Kindergarten and Public Policy in Germany, 1840 - Present.” In Kindergartens and Cultures: The Global Diffusion of an Idea, edited by Roberta Wollons, 16-41. New Haven, CT: Yale University Press, 2000.

Ariés, Philippe. Centuries of Childhood: A Social History of Family Life. Translated by Robert Baldick. New York: Vintage Books, 1962.

Armus, Diego. The Ailing City: Health, Tuberculosis, and Culture in Buenos Aires, 1870-1950. Durham and London: Duke University Press, 2011. 
. Health, Tuberculosis, and Culture in Buenos Aires, 1870-1950. Durham and London: Duke University Press, 2011. Amazon Kindle E-Book.

Álvarez, Adriana. “La Experiencia de Ser un ‘niño Débil y Enfermo’ Lejos de Su Hogar: El Caso del Asilo Marítimo, Mar del Plata (1893-1920).” História, Ciências, Saúde-Manguinhos 17, no. 1 (January-March 2010): 13-31.

Álvarez, Adriana, and Daniel Reynoso. "Entre el Abandono y la Debilidad. El Cuidado de la Salud en la Primera Infancia, 1920-1930.” In Infancias: Políticas y Saberes en la Argentina y Brasil: Siglos XIX y XX, edited by Isabella Cosse and [et. al.], 123-48. Buenos Aires: Teseo, 2011.

Bailey, Dorothy Dee. "Early History of the Argentine Normal Schools.” Peabody Journal of Education 36, no. 1 (July 1958): 16-26.

Baily, Samuel L. Immigrants in the Lands of Promise: Italians in Buenos Aires and New York City. Ithaca, NY: Cornell University Press, 1999.

Baily, Samuel L. "Marriage Patterns and Immigrant Assimilation in Buenos Aires, 18821923.” Hispanic American Historical Review (1980).

Balan, Jorge, Harley L Browning, and Elizabeth Jelin. Men in Developing Society; Geographic and Social Mobility in Monterrey, Mexico. Austin: University of Texas Press, 1973.

Bartolomé, Miguel Alberto. “Los Pobladores Del’ Desierto’ Genocidio, Etnocidio y Etnogénesis en la Argentina.” Cuadernos de Antropología Social 17 (2003): 16289.

Baxter, Jane Eva. The Archaeology of Childhood: Children, Gender, and Material Culture. Gender and Archaeology Series, vol. 10. Walnut Creek, CA: AltaMira Press, 2005.

Blum, Ann S. Domestic Economies: Family, Work and Welfare in Mexico City, 18841943. Lincoln: University of Nebraska Press, 2009.

_. "Public Welfare and Child Circulation, Mexico City, 1877-1925.” Journal of Family History 23, no. 3 (1998): 240-71.

Boocock, Sarane Spence, and Kimberly Ann Scott. Kids in Context: The Sociological Study of Children and Childhood. Lanham, Md.: Rowman \& Littlefield Publishers, 2005.

Brannen, J, and M O’Brien. “Childhood and the Sociological Gaze: Paradigms and Paradoxes.” Sociology 29 (1995): 729-37.

Calvert, Karin. Children in the House: The Material Culture of Early Childhood, 1600 1900. Boston: Northeastern University Press, 1992.

Campbell, Margaret. "What Tuberculosis Did for Modernism: The Influence of a Curative Environment on Modernist Design and Architecture." Medical History 49, no. 4 (October 2005): 463-88. 
Carli, Sandra. "The new school movement in Argentina." Paedagogica historica42, no. 03 (2006): 385-404.

Carlson, Marifran. i Feminismo!: The Woman's Movement in Argentina. Chicago Review Press, 2005.

Chawla, Louise. "Revisioning Childhood, Nature, and the City.” Architecture and Behaviour 10, no. 4 (1994): 343-50.

Ciafardo, Eduardo O. Los Niños en la Ciudad de Buenos Aires (1890-1910). Centro Editor de América Latina, 1992.

Cook, Daniel Thomas. The Commodification of Childhood: The Children's Clothing Industry and the Rise of the Child Consumer. Durham: Duke University Press, 2004.

Le Corbusier. Looking at City Planning. 1st. Eleanor Levieux. New York: Grossman Publishers, 1971.

Cunningham, Hugh. "Histories of Childhood.” The American Historical Review 103, no. 4 (October 1998): 1195-208.

Davies, Catherine, Claire Brewster, and Hilary Owen. South American Independence: Gender, Politics, Text. Liverpool: Liverpool University Press, 2006.

Davin, Anna. Growing up Poor: Home, School, and Street in London, 1870-1914. London: Rivers Oram Press ; Concord, MA: Paul and Company, 1996.

del Castillo Troncoso, Alberto. "Imágenes y Representaciones de la Niñez en México en el Cambio del Siglo XIX al XX.” Cuicuilco. Revista de la Escuela Nacional de Antropología e Historia 10, no. 29 (2003): 141-68.

Delaney, Jean H. "Imagining El Ser Argentino: Cultural Nationalism and Romantic Concepts of Nationhood in Early Twentieth-Century Argentina.” Journal of Latin American Studies 34, no. 3 (August 2002): 625-58.

Delaney, Jeane. "Making Sense of Modernity: Changing Attitudes Toward the Immigrant and the Gaucho in Turn-of-the-Century Argentina." Comparative Studies in Society and History 38, no. 03 (July 1996).

Dominick, Cavallo. Muscles and Morals: Organized Playgrounds and Urban Reform, 1880-1920. Philadelphia: University of Pennsylvania Press, 1981.

Dovio, Maríana Angela. “El Caso de la ‘Mala Vida’ en la Revista de Criminología, Psiquiatría y Medicina Lecal (1914-1927) en Buenos Aires: Entre La Peligrosidad y La Prevención.” Revista de Historia del Derecho, no. 43 (enerojunio 2012): 1-29.

Eylers, Eva. "Planning the Nation: The Sanatorium Movement in Germany.” The Journal of Architecture 19, no. 5 (2014): 667-92. 
Favio, Leonardo. Perón, sinfonía del sentimiento. Documentary. Producer Victor Bassuk and Javier Leoz. Argentina, 1999.

Formanek-Brunell, Miriam. Made to Play House, Dolls and the Commercialization of American Girlhood, 1830-1930. Baltimore: The Johns Hopkins University Press, 1998.

Foster, David William. Buenos Aires: Perspectives on the City and Cultural Production. Gainesville: University Press of Florida, 1998.

Fraser, Nicholas and Marysa Navarro. Evita. New York: W. W. Norton and Company, 1996.

Frisch, Michael H. "Urban Theorists, Urban Reform, and American Political Culture in the Progressive Period.” Political Science Quarterly 97, no. 2 (Summer 1982): 295-315.

Frost, Joe L. A History of Children's Play and Play Environments: Toward a Contemporary Child-Saving Movement. New York: Routledge, 2010.

Gillis, John R. "Epilogue: The Islanding of Children - Reshaping the Mythical Landscapes of Childhood.” In Designing Modern Childhoods: History, Space, and the Material Culture of Children, edited by Marta Gutman and Ning Coninck-Smith, 316-30. New Brunswick: Rutgers University Press, 2008.

Gorelik, Adrián. La Grilla y el Parque: Espacio Público y Cultura Urbana en Buenos Aires, 1887-1936. La Ideología Argentina Ideología Argentina (Universidad Nacional de Quilmes). Buenos Aires: Universidad Nacional de Quilmes, 1998.

Guano, Emanuela. "A Stroll Through la Boca: The Politics and Poetics of Spatial Experience in a Buenos Aires Neighborhood.” Space and Culture 6, no. 4 (November 2003): 356-76.

Gutiérrez, Ramón. “Buenos Aires, A Great European City.” In Planning Latin America’s Capital Cities 1850-1950, edited by Arturo Almandoz, 45-74. London; New York: Routledge, 2002.

- "BuenosAires, A Great European City.” In Planning Latin America’s Capital Cities, 1850-1950, edited by Arturo Almandoz, 45-74. London: Routledge, 2002.

Gutman, Marta, and Ning de Coninck-Smith. "Introduction: Good to Think With History, Space, and Modern Childhood.” In Designing Modern Childhoods: History, Space, and the Material Culture of Children, edited by Marta Gutman and Ning de Coninck-Smith, 1-19. New Brunswick: Rutgers University Press, 2008.

Guy, Donna J. “The Pan American Child Congresses, 1916-1942: Pan Americanism, Child Reform, and the Welfare State in Latin America.” Journal of Family History 23, no. 3 (0272-91 1998).

Sex and Danger in Buenos Aires: Prostitution, Family, and Nation in Argentina. Lincoln: University of Nebraska Press, 1991. 
- Women Build the Welfare State: Performing Charity and Creating Rights in Argentina, 1880-1955. Durham and London: Duke University Press, 2009.

Hanawalt, Barbara A. Growing Up in Medieval London: The Experiences of Childhood in History. New York: Oxford University Press, 1993.

Hardoy, Jorge, ed. Urbanization in Latin America: Approaches and Issues. Garden City, NJ: Anchor Books, 1975.

Hawes, Joseph M., and N. Ray Hiner. "Hidden in Plain View: The History of Children (and Childhood) in the Twenty-First Century." Journal of the History of Childhood and Youth 1, no. 1 (Winter 2008): 43-49.

Hech, Tobias. At Home in the Street: Street Children of Northeast Brazil. Cambridge University Press, 1998.

Hecht, Tobias. “Introduction.” In Minor Omissions: Children in Latin American History and Society, edited by Tobias Hecht, 3-20. Madison: University of Wisconsin, 2002.

Herrero, Alejandro. "Liberalismo y Democracia en Argentina. El Estudio de un Caso: Ernesto Nelson: ¿Un Educador del Estado en Contra del Estado?” Utopía y Praxis Latinoamericana 11, no. 33 (abril-junio 2006): 103-08.

Hobsbawm, E.J. Nations and Nationalism Since 1780: Programme, Myth, Reality. Cambridge [England: Cambridge University Press, 1992.

Hoganson, Kristin L. Consumers' Imperium: The Global Production of American Domesticity, 1865-1920. Chapel Hill: University of North Carolina Press, 2007.

Holloway, Sarah L., and Gill Valentine. "Children’s Geographies and the New Social Studies of Childhood.” In Childhood: Critical Concepts in Sociology, 163-88. London: Routledge, 2005.

Holloway, Sarah, and Gill Valentine, eds. Children’s Geographies: Playing, Living, Learning. Critical Geographies. London ; New York, N.Y.: Routledge, 2000.

Horton, John, Peter Kraftl, and Faith Tucker. "The Challenges of 'Children's Geographies': A Reaffirmation (Editorial Introduction).” Children's Geographies 6, no. 4 (2008): 335-48.

Jaksic, Ivan. The Hispanic World and American Intellectual Life, 1820-1880. New York: Palgrave Macmillan, 2007.

James, Allison, and Alan Prout, eds. Constructing and Reconstructing Childhood: Contemporary Issues in the Sociological Study of Childhood. London ; New York: Falmer Press, 1990.

James, Daniel. Resistance and Integration: Peronism and the Argentine Working Class, 1946-1976. Cambridge Latin American Studies. Cambridge ; New York: Cambridge University Press, 1988. 
Jenks, Chris. Childhood. London ; New York: Routledge, 2002.

Kelly, Catriona. Children's World: Growing up in Russia, 1890-1991. New Haven, Conn.: Yale University Press, 2007.

Kezer, Zeynep. "Molding the Republican Generation: The Landscapes of Learning in Early Republican Turkey.” In Designing Modern Childhoods: History, Space, and the Material Culture of Children, 128-51, 2008.

Kuznesof, Elizabeth. “The House, the Street, Global Society: Latin American Families and Childhood in the Twenty-First Century.” Journal of Social History, Summer 2005, 859-72.

Lakoff, Andrew. “The Simulation of Madness: Buenos Aires, 1903.” Critical Inquiry 31, no. 4 (Summer 2005): 848-73.

Larson, Dolane. “Fundacion Eva Peron: Education - Student’s City.” Summary. Fundacion de Investigaciones Historicas Evita Peron, 2002.

Http://www.evitaperon.org.

_ . "Fundacion Eva Peron: Education - The Amanda Allen Children's City.” Summary. Fundacion de Investigaciones Historicas Evita Peron, 2002.

Http://www.evitaperon.org.

Lauderdale Graham, Saundra. House and Street: The Domestic World of Servants and Masters in Nineteenth-Century Rio de Janeiro. Cambridge: Cambridge University Press, 1988.

Lear, John. “Mexico City: Space and Class in the Porfirian Capital, 1884-1910.” Journal of Urban History 22, no. 4 (May 1996): 454-92.

Lefebvre, Henri. The Production of Space. Donald Nicholson-Smith. Oxford: Blackwell Publishers Ltd, 1991.

Lois, Carla. “Measuring Up and Fitting In.” In Mapping Latin America, edited by Jordana Dym and Karl Offen, 163-67. Chicago and London: The University of Chicago Press, 2011.

Marcus, G, and M Fisher. "A Crisis of Representation in the Human Sciences and Ethnography and Interpretive Anthropology.” In Anthropology as Cultural Critique: An Experimental Moment in the Human Sciences, 7-44. Chicago: University of Chicago Press, 1986.

Martínez, María Elena. “Space, Order and Group Identities in a Spanish Colonial Town: Puebla de los Angeles.” In The Collective and the Public in Latin America: Cultural Identities and Political Order, edited by Luis Roniger, Tamar Herzog, 13-36. Brighton: Sussex Academic Press, 2000.

Mead, Karen. "Beneficent Maternalism: Argentine Motherhood in Comparative Perspective, 1820-1920.” Journal of Women’s History 12, no. 3 (Autumn 2000): $120-45$. 
Meik, Kindon T. "Disease and Hygiene in the Construction of Nation: The Public Sphere, Public Space, and the Private Domain in Buenos Aires, 1871-1910.” Ph.D. diss. FIU Electronic Theses and Dissertations Paper 547 (2011). Florida International University. Http://digitalcommons.fiu.edu/etd/547.

Mellafe, Rolando. “Review: Urban Studies: A Bibliographic Explosion.” Journal of Interamerican Studies and World Affairs 17, no. 1 (February 1975): 101-08.

Mero, Everett B., ed. American Playgrounds: Their Construction, Equipment, Maintenance and Utility. New York: The Baker \& Taylor Co., 1908.

Milanich, Nara. “The Casa de Huérfanos and Child Circulation in Late-NineteenthCentury Chile.” Journal of Social History 38, no. 2 (2004): 311-40.

. Children of Fate: Childhood, Class and the State in Chile, 1850-1930. Durham: Duke University Press, 2009.

Mintz, Steven. Huck's Raft, A History of American Childhood. Cambridge: Belknap Press of Harvard University Press, 2004.

Mitchell, Sally. The New Girl: Girls' Culture in England, 1880-1915. New York: Columbia University Press, 1995.

Morse, Richard M. From Community to Metropolis: A Biography of São Paulo, Brazil. Gainesville: University of Florida Press, 1958.

. “Trends and Issues in Latin American Urban Research, 1965-1970.” Latin American Research Review 6, no. 2 (Summer 1971): 19-75.

_. "Trends and Patterns of Latin American Urbanization, 1750-1920." Comparative Studies in Society and History 16, no. 4 (September 1974): 416-47.

Movement, Missionary Education. Christian Work in Latin America Survey and Occupation, Message and Method Education Being the Reports of the Commissions, I, Ii and III Presented to the Congress on Christian Work in Latin America, Panama, February, 1917. London: Forgotten Books, 2013, reprint.

Moya, José C. Cousins and Strangers: Spanish Immigrants in Buenos Aires, 1850-1930. Berkeley: University of California Press, 1998.

Municipalidad de La Plata. “Edificios.” Edicicios de La Republica de Los Niños. Summary. Palacio Municipal, La Plata, Buenos Aires. Http://www.republica.laplata.gov.ar/edificios/inicio.htm.

. "Historia del Proyecto.” Historia de La Republica de los Niños. Summary. Palacio Municipal, La Plata, Buenos Aires. http://www.republica.laplata.gov.ar/historia/inicio.htm.

. “Mapa.” Plano del Predio de La Republica de los Niños. Map. Palacio Municipal, La Plata, Buenos Aires. http://www.republica.laplata.gov.ar/mapa/inicio.htm. 
n.a. “Se Inaugura la 'República de los Niños,' en Gonnet, Localidad Cercana a La Plata. Estuvieron Presentes Miles de Escolares.” Photograph, enfrente de la casa gobierna. Eva Peron - Mujer Leyenda - Imagenes de Evita, 1951.

Http://mariaevaperon.blogspot.com/2007/03/ms-imagenes-de-evita.html.

Needell, Jeffrey D. "Rio de Janeiro and Buenos Aires: Public Space and Public Consciousness in Fin-de-Siecle Latin America.” Comparative Studies in Society and History 37 (1995): 519-40.

Newton, Ronald. German Buenos Aires, 1900-1933: Social Change and Cultural Crisis. Austin: University of Texas Press, 1977.

Peard, Julyan G. "Enchanted Edens and Nation-Making: Juana Manso, Education, Women and Trans-American Encounters in Nineteenth-Century Argentina." Journal of Latin American Studies 40, no. 3 (0453-82 2008).

Pírez, Pedro. "Buenos Aires: Fragmentation and Privatization of the Metropolitan City.” Environment and Urbanization 14, no. 1 (April 2002): 145-58.

Plotkin, Mariano Ben. Manana es San Peron: A Cultural History of Peron's Argentina. Wilmington, Del: Scholarly Resources, 2002.

Plotkin, Mariano. “The Changing Perceptions of Peronism.” In Peronism and Argentina, edited by James P. Brennan, 29-54. Wilmington: SR Books, 1998.

Portes, Alejandro, and Harley L Browning, eds. Current Perspectives in Latin American Urban Research. Austin: University of Texas Press, 1976.

Premo, Bianca. “How Latin America’s History of Childhood Came of Age.” Journal of the History of Childhood and Youth 1, no. 1 (Winter 2008): 63-76.

Radcliffe, Sarah A. "Geographies of Modernity in Latin America: Uneven and Contested Development.” In When Was Latin America Modern? edited by Nicola Miller and Stephen Hart, 21-4? New York, NY: Palgrave Macmillan, 2007.

Read, Jane. "Froebelian Women: Networking to Promote Professional Status and Educational Change in the Nineteenth Century.” History of Education 32, no. 1 (2003): 17-33.

Reber, Vera Blinn. "Poor, Ill, and Sometimes Abandoned: Tubercular Children in Buenos Aires, 1880-1920.” Journal of Family History 27, no. 2 (April 2002): 128-49.

_ . "The Sanatorium Age Pennsylvania and Arentina, 1900-1945.” Pennsylvania History: A Journal of Mid-Atlantic Studies 73, no. 4 (2006): 412-45.

Rein, Monica Esti, Martha Grenzeback, trans. Politics and Education in Argentina 19461962. Latin American Realities, Robert M. Levine, Series Editor. Armonk, New York: M.E. Sharpe, 1998.

Ríos, Julio Césad, and Ana María Talak. La Niñez en los Espacios Urbanos. Taurus, 2002. 
Roberts, Bryan R. “Globalization and Latin American Cities.” International Journal of Urban and Regional Research 29, no. 1 (March 2005): 110-23.

Rock, David. Argentina 1516-1987: From Spanish Colonization to Alfonsin. Berkeley Los Angeles: University of California Press, 1987.

—. Authoritarian Argentina: The Nationalist Movement, Its History and Its Impact. Berkeley, CA: University of California Press, 1993.

Romero, José Luis. Latinoamérica: Las Ciudades y las Ideas. Mexico City: Siglo veintiuno, 1976.

Rosenthal, Anton. "Spectacle, Fear, and Protest: A Guide to the History of Urban Public Space in Latin America.” Social Science History 24, no. 1 (2000): 33-73.

Ryan, Patrick J. "How New Is the 'New' Social Study of Childhood? The Myth of a Paradigm Shift.” The Journal of Interdisciplinary History 38, no. 4 (Spring 2008): 553-76.

Sargent, Charles S. The Spatial Evolution of Greater Buenos Aires, Argentina, 1870 1930. Center for Latin American Studies: Arizona State University, 1971.

Sarmiento 1811-1888, Domingo Faustino. Facundo, or Civilization and Barbarism. Translated by Mary Mann, with an introduction by Ilan Stavans. New York, NY: Penguin Books, 1998.

Schell, Patience A. "Nationalizing Children Through Schools and Hygiene: Porfirian and Revolutionary Mexico City.” The Americas 60, no. 4 (2004): 559-87.

Schultz, James A. The Knowledge of Childhood in the German Middle Ages, 1100-1350. Philadelphia: University of Pennsylvania Press, 1995.

Scobie, James R. "Buenos Aires as a Commercial-Bureaucratic City, 1880-1910: Characteristics of a City's Orientation.” The American Historical Review 77, no. 4 (October 1972): 1035-73.

Scobie, James R. Buenos Aires: Plaza to Suburb, 1870-1910. New York: Oxford University Press, 1974.

Shahar, Shulamith. Childhood in the Middle Ages. London; New York: Routeledge, 1990.

Shanahan, Suzanne. "Lost and Found: The Sociological Ambivalence Toward Childhood.” Annual Review of Sociology 33 (2007): 407-28.

Shumway, Nicolas. The Invention of Argentina. Berkeley: University of California Press, 1991.

Sofer, Eugene F. From Pale to Pampa: A Social History of the Jews of Buenos Aires. New York: Hill and Wang, 1982. 
Sofer, Eugene F., and Mark D. Szuchman. “City and Society: Their Connection in Latin American Historical Research.” Latin American Research Review 14, no. 2 (1979): 113-29.

Soja, Edward W. Postmodern Geographies: The Reassertion of Space in Critical Social Theory. London: Verso, 1989.

Southwell, Myriam. “Juana P. Manso (1819-1875).” Perspectivas: Revista Trimestral de Educación Comparada XXXV, no. 1 (Marzo 2005): 117-32.

Spalding Jr., Hobart A. "Education in Argentina, 1890-1914: The Limits of Oligarchical Reform.” The Jornal of Interdisciplinary History 3, no. 1 (Summer 1972): 31-61.

Stearns, Peter N. Anxious Parents: A History of Modern Childrearing in America. New York; London: New York University Press, 2003.

Stewart, Watt, and William Mashall French. "The Influence of Horace Mann on the Educational Ideas of Domingo Faustino Sarmiento.” The Hispanic American Historical Review 20, no. 1 (February 1940): 12-31.

Suriano, Juan. Paradoxes of Utopia: Anarchist Culture and Politics in Buenos Aires, 1890-1910. AK Press, 2010.

Szuchman, Mark D. “Childhood Education and Politics in Nineteenth-Century Argentina: The Case of Buenos Aires.” Hispanic American Historical Review 70, no. 1 (February 1990): 109-38.

— . "Constructing the City, Constructing the State: Architecture and Political Transition in Urban Argentina, 1810-1860.” In State and Society in Spanish America During the Age of Revolution, Victor M. Uribe-Uran, 193-218. Wilmington, DE: Scholarly Resources Inc., 2001.

Szuchman, Mark D. Mobility and Integration in Urban Argentina: Córdoba in the Liberal Era. Austin: University of Texas Press, 1980.

Szuchman, Mark D. Order, Family, and Community in Buenos Aires, 1810-1860. Stanford: University Press, 1988.

—. "Raising the Nation: Childhood, Education, and the State in Nineteenth- and Twentieth Century Latin America.” American Historical Association, 2007.

Taylor, Diana. Disappearing Acts: Spectacles of Gender and Nationalism in Argentina's "Dirty War". Durham and London: Duke University Press, 1997.

Tenorio-Trillo, Mauricio. Mexico at the World's Fairs: Crafting a Modern Nation. Berkeley: University of California Press, 1996.

Torre, Juan Carlos. “La Democratizacion del Bienstar.” In Nueva historia argentina: los anos peronistas (1943-1955), edited by Juan Carlos Torre. Buenos Aires:

Editorial Sudamericana, 2002. 
Troncoso, Alberto del Castillo. "Entre la Criminalidad y el Orden Cívico: Imágenes y Representaciones de la Niñez Durante el Porfiriato.” Historia Mexicana (1998).

unknown. "Una Republica a la Medida de los Chicos; Magica Leyenda: La Ciudad Que Inspiro a Walt Disney.” Hoy Interes General, La Plata (2 agosto 2004): 12.

—_. "Time Out.” Time Magazine, 22 November 1948.

Uprichard, Emma. "Children as Being and Becomings: Children, Childhood and Temporality.” Children \& Society 22, no. 4 (July 2008): 303-13.

Uribe-Uran, Victor M. "The Birth of a Public Sphere in Latin America During the Age of Revolution.” Comparative Studies in Society and History 42, no. 2 (April 2000): 425-57. Cambridge University Press.

Van Slyck, Abigail A. "Connecting with the Landscape: Campfires and Youth Culture at American Summer Camps, 1890-1950.” In Designing Modern Childhoods: History, Space, and the Material Culture of Children, 23-41, 2008.

Vaughan, Mary K, and Stephen Lewis. The Eagle and the Virgin: Nation and Cultural Revolution in Mexico, 1920-1940. Durham: Duke University Press, 2006.

Vegesack, Alexander von, Jutta Odiges, and Bullivant, eds. Kid Size: The Material World of Childhood. Milan: Skira editore, 1997.

Walton, John. "From Cities to Systems: Recent Research on Latin American Urbanization.” Latin American Research Review 14, no. 1 (1979): 159-69.

Warf, Barney, and Santa Arias. "Introduction: The Reinsertion of Space Into the Social Sciences and Humanities.” In The Spatial Turn: Interdisciplinary Perspectives, edited by Barney Warf and Santa Arias, 1-10. New York: Routledge, 2009.

Yujnovsky, Oscar. Notes on Research on the Urban Spatial Configuration and Land Use Policies in Latin America. Austin: University of Texas Press, 1974.

Zapiola, María Carolina. "La Invención del Menor: Representaciones, Discursos y Políticas Públicas de Menores en la Ciudad de Buenos Aires, 1882-1921.” Tesis de Maestría. Buones Aires: UNSAM, 2007.

- "Los Niños Entre la Escuela, el Taller y la Calle. Buenos Aires, 1884-1915." Cadernos de Pesquisa, Fundaçao Carlos Chagas 39, no. 1 (Janeiro/Abril 2009): 69-81. 
VITA

MELISSA MALONE

Born, Gainesville, Florida

2002-2005

B.A., Political Science and

Latin American and Caribbean Studies

Florida Academic Scholar

Florida State University

Tallahassee, Florida

2006-2015

2006-2010

Doctoral Candidate

Florida International University

Miami, Florida

Teaching Assistant

Florida International University

Miami, Florida

2010

Dissertation Evidence Acquisition Fellowship

Florida International University

Miami, Florida

2011

Tinker Field Research Grant

Florida International University

Miami, Florida

2011

2012-2013

The Wolfsonian-FIU Research Fellowship

The Wolfsonian-Florida International University

Miami Beach, Florida

Dissertation Year Fellowship

Florida International University

Miami, Florida

2013

Co-Founder

Five One Digital

Sunrise, Florida

2014

Director of Operations

Parapharama Tech

Coral Springs, Florida 